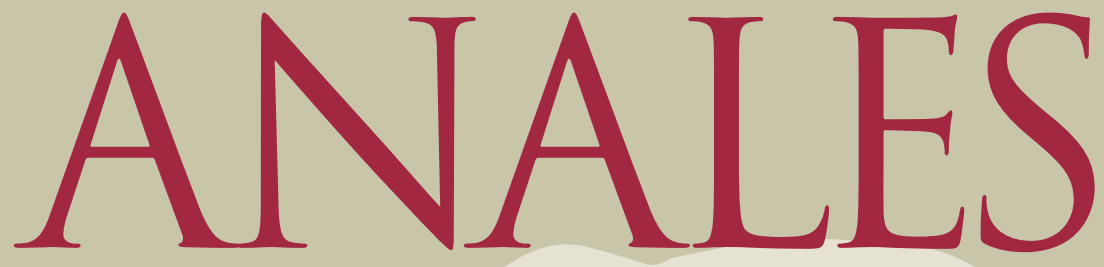

de la Facultad de Derecho

Universidad de La Laguna $36 \quad 2019$ 
Anales de la Facultad de DERECHO 


\section{Anales de la Facultad de DERECHO}

Universidad de La Laguna

DIRECTORA

María Victoria Sansón Rodríguez (ULL)

SUBDIRECTOR

Francisco Lorenzo Hernández González (ULL)

SECRETARIO DE LA REVISTA

Juan Antonio García García (ULL)

CONSEJO DE REDACCIÓN

Marcel Bonnet Escuela (ULL), Etelvina de las Casas León (ULL),

Francisco F. Clavijo Hernández (ULL), Ulises Hernández Plasencia (ULL),

Tomás López-Fragoso Álvarez (ULL), Ruth Martinón Quintero (ULL),

Margarita I. Ramos Quintana (ULL), María Elena Sánchez Jordán (ULL).

\section{CONSEJO ASESOR}

Andrea Bonomi (Université de Lausanne, Suiza), Martín Diego Farrell (Universidad de Buenos Aires, Argentina), Antonio Fernández de Buján (Universidad Autónoma de Madrid), Cesare Maioli (Università di Bologna, Italia), María Elvira Méndez Pineda

(University of Iceland, Islandia), Manuel Carlos Palomeque López (Universidad de Salamanca), María Ángeles Parra Lucán (Universidad de Zaragoza), Johann-Christian Pielow (Ruhr-Universität Bochum, Alemania), Carlos M. ${ }^{a}$ Romeo Casabona (Universidad del País Vasco), María del Carmen Sevilla González (Universidad de La Laguna), Esteban Sola Reche (Universidad de La Laguna), Rolando Tamayo Salmarán (Universidad Nacional

Autónoma de México), Francisco José Villar Rojas (Universidad de La Laguna), Stefan Vogenauer (University of Oxford, Reino Unido).

\section{EDITA}

Servicio de Publicaciones de la Universidad de La Laguna Campus Central. 38200 La Laguna. Santa Cruz de Tenerife Tel.: 34922319198

\section{DISEÑO EDITORIAL}

Jaime H. Vera

Javier Torres/Luis C. Espinosa

\section{MAQUETACIÓN Y PREIMPRESIÓN}

Servicio de Publicaciones

DOI: https://doi.org/10.25145/j.anfade.2019.36

ISSN: 0075-773X (edición impresa) / ISSN: e-2530-8319 (edición digital)

Depósito Legal: TF 734/81

Prohibida la reproducción total o parcial de esta obra sin permiso del editor. 


\section{Anales de la Facultad de DERECHO}


ANALES de la Facultad de Derecho de la Universidad de La Laguna. -La Laguna: Universidad, Servicio de Publicaciones, 1991-

Anual

Es continuación de: Anales de la Universidad de La Laguna. Facultad de Derecho.

ISSN 0075-773X

1. Derecho-Publicaciones periódicas I. Universidad de La Laguna. Facultad de Derecho. 34(05)

La correspondencia relativa a la revista debe dirigirse a:

Anales de la Facultad de Derecho

Servicio de Publicaciones

Universidad de La Laguna

Campus Central

38200 La Laguna (Tenerife, España) 


\section{SUMARIO / CONTENTS}

\section{Artículos / Articles}

El factum principis como técnica de equilibrio económico del contrato administrativo / The factum principis as a technique of economic equilibrium of the administrative contract

Reflexiones sobre la evolución legislativa y jurídica de los derechos de las mujeres en España: desde la Segunda República hasta la actualidad / Reflections on the legislative and judicial evolution of women's rights in Spain: from the Second Republic to the present

Dan Stanforth, Aurelio Santana Rodríguez y José Andrés Salgado Fernández

Comentarios sobre la insularidad de La Graciosa en el nuevo Estatuto de Autonomía de Canarias / Comments on the insularity of La Graciosa in the new Statute of Autonomy of the Canary Islands 

ARTÍCULOS / ARTICLES 



\title{
EL FACTUM PRINCIPIS COMO TÉCNICA DE EQUILIBRIO ECONÓMICO DEL CONTRATO ADMINISTRATIVO
}

\author{
María Matute Botella \\ Investigadora del Área de Derecho Administrativo, ULL
}

\section{RESUMEN}

El factum principis o "hecho del príncipe» es una técnica de equilibrio económico consolidada en nuestro ordenamiento jurídico que, desde sus orígenes, se ha visto amenazada por el fortalecimiento de otras técnicas que lo han ido ensombreciendo. La nueva Ley de Contratos del Sector Público circunscribe su ámbito de actuación a unos límites más precisos que en su concepción tradicional, pero que permiten disipar las dudas sobre su utilidad y funcionamiento, dándole la oportunidad de convertirse en una opción real para la solución de problemas en la contratación administrativa.

Palabras Clave: factum principis, contratación administrativa, Ley de Contratos del Sector Público de 2017.

\section{THE FACTUM PRINCIPIS AS A TECHNIQUE OF ECONOMIC EQUILIBRIUM} OF THE ADMINISTRATIVE CONTRACT

\section{Abstract}

The factum principis or "act of the prince» is a technique of economic equilibrium consolidated in our legal system. Since its origins it has been threatened by the strengthening of other techniques that have overshadowed it. The new Law on Public Sector Contracts circumscribes its scope of action to more precise limits than in its traditional conception but which allow doubts about its usefulness and operation to be eliminated. This figure has the opportunity to become a real option for solving problems in administrative contracting. KeYwords: factum principis, administrative contracting, 2017 Public Sector Contract Law. 


\section{NACIMIENTO Y POSITIVACIÓN DE LA TEORÍA DEL FACTUM PRINCIPIS}

El factum principis o «hecho del príncipe» es un producto de la doctrina y jurisprudencia que posteriormente se incorporó al ordenamiento jurídico positivo. Con esta expresión se alude a la obligación que tiene la Administración de compensar al contratista cuando, por actuaciones propias - generales y obligatorias- que se mueven en un plano superior a la relación contractual, se provoque (de forma indirecta) un desequilibrio de las prestaciones en perjuicio del contratista ${ }^{1}$. Es una técnica de equilibrio económico del contrato administrativo que coexiste con la compensación por el ejercicio del ius variandi, el riesgo imprevisible y la fuerza mayor.

El precedente más inmediato del reconocimiento del factum principis en la contratación administrativa se encuentra en la Sentencia del Tribunal Supremo de 7 de marzo de 1895 (asunto Compañía de Aguas Potables de Cádiz) sobre un contrato de obras de ampliación del puerto de Málaga, cuyo precio había aumentado por la implantación de nuevos aranceles sobre la cal hidráulica que debía emplearse². El Tribunal Supremo se pronunció a favor del contratista, al considerar que se había impuesto un gravamen injustificado e imprevisible que generaba un enriquecimiento en beneficio de la Administración como consecuencia de un acto propio alejado de los cambios de mercado y que, por tanto, debía indemnizarse. A raíz de esto empieza a surgir una tendencia favorable a aplicar el factum principis cuando medidas generales e imprevisibles de índole económica perjudicaran al contratista y generaran un enriquecimiento injusto a favor de la Administración.

Sin embargo, este principio no se plasma en los textos legales hasta la Ley de 17 de julio de 1945 sobre revisión de precios en los proyectos de obras adjudicados por subasta o concurso, tal y como dice su exposición de motivos: «Los aumentos en el coste de los elementos de los precios unitarios a tener en cuenta en las revisiones de los mismos no pueden ser otros que los autorizados por disposiciones de la Administración pública con eficacia bastante para ser impuestos en la ejecución de las obras contratadas por el Estado». Desde este momento quedan dibujadas las

\footnotetext{
${ }^{1}$ García de Enterría, E. y Fernández Rodríguez, T.R., Curso de Derecho Administrativo, I, 5. ${ }^{a}$ ed., Civitas, Madrid, 1992, p. 709.

2 Ariño Ortiz, G., Teoría del equivalente económico en los contratos administrativos, IEA, Madrid, 1968, pp. 255, 256 y 261: este autor lo localizó en el arrendamiento de rentas del Antiguo Régimen. Sin embargo, no se solía aplicar por la fuerte implantación que tenía el principio de riesgo y ventura del empresario sobre esta figura y, además, por tres principios característicos de la época: principio de soluta potestas, por el que el príncipe nunca quedaba completamente obligado por los contratos que suscribía; principio de irresponsabilidad del príncipe, por el que no respondía de las lesiones que causaba a los súbditos, siempre que la causa de la lesión fuera suficiente; y principio de seguridad y certidumbre de los ingresos fiscales, por el que no se podía obstaculizar el arrendamiento de rentas por ser el principal medio de recaudación del reino. De esta forma, prácticamente todas las actuaciones que realizaba el rey en perjuicio de los súbditos quedaban justificadas en alguno de los principios anteriores, siempre y cuando fueran un reflejo de las facultades de «buen gobierno». Por tanto, no surgía ningún derecho de compensación por tales circunstancias a favor de los lesionados.
} 
líneas definitorias del factum principis, como son el carácter general, la ajenidad al contrato y su imprevisibilidad ${ }^{3}$.

En la Ley de Contratos del Estado de 1965 no se recoge de forma expresa el factum principis, aunque hay autores que lo sitúan en la causa de resolución recogida en el artículo $80^{4}$. El primero de estos preceptos establece: «Cuando la explotación del servicio se haga imposible como consecuencia de acuerdos adoptados por la Administración con posterioridad al contrato, el empresario podrá pedir la resolución...». La misma redacción encontramos en el artículo 168 d) de Ley de Contratos de las Administraciones Públicas de $1995^{5}$. En ambos supuestos, la causa de resolución va acompañada del derecho del empresario a percibir una indemnización por los daños y perjuicios causados por la circunstancia que da lugar a la resolución del contrato, lo que abarcará tanto el daño emergente como el lucro cesante ${ }^{6}$.

Posteriormente, la Ley 13/2003, reguladora del contrato de concesión de obra pública, es la primera norma en la que el legislador incorpora de forma inequívoca el factum principis en el marco del mantenimiento del equilibrio económico, en el artículo 248.2, d) cuando hace referencia a actuaciones de la Administración, contraponiéndolo al ius variandi ${ }^{7}$ : "Cuando causas de fuerza mayor o actuaciones de la Administración determinaran de forma directa la ruptura sustancial de la economía de la concesión».

A partir de este momento el factum principis se consolida en la contratación administrativa reproduciéndose la redacción heredada de la Ley 13/2003, quedando circunscrita a las concesiones de obras y a los contratos de gestión de servicios públicos. Así sucede en la Ley de Contratos del Sector Público de 2007 (arts. 241.2 b y 258.4 b) y en el Texto Refundido de 2011 (arts. 258.2 b y 282.4 b). Finalmente, la Ley actual lo contempla de forma específica para la concesión de obra pública en el artículo 270.2 b) y para la concesión de servicios en el 290.4 b) ${ }^{8}$ : «Cuando actua-

3 Albendea Solís, I. y León González, A., «El reequilibrio económico de los contratos», en Gamero Casado, E. y Gallego Córcoles, I. (dirs.), Tratado de Contratos del Sector Público, tomo I, Tirant lo blanch, Valencia, 2018, p. 2296.

${ }^{4}$ García de Enterría, E. y Fernández Rodríguez, T.R., Curso de Derecho Administrativo, I, 14. ${ }^{a}$ ed., Civitas, Madrid, 2008, p. 754 y Albendea Solís, I, y León González, A., «El reequilibrio económico de los contratos», en Gamero Casado, E. y Gallego Córcoles, I. (dirs.), Tratado de Contratos del Sector..., ob. cit., p. 2297.

5 Art. 168 d) LCAP 1995: «La imposibilidad de la explotación del servicio como consecuencia de acuerdos adoptados por la Administración con posterioridad al contrato».

${ }^{6}$ Art. 80 LCE: «La indemnización al empresario se sujetará a lo dispuesto en el artículo anterior»; lo que se complementa con el art. 79 LCE, que establece: «... habida cuenta de su grado de amortización y los daños y perjuicios que se le irroguen así como los beneficios futuros que deje aquel de percibir...»; y art. 170.4: «En los supuestos de las letras b), c) y d) del artículo 168, sin perjuicio de lo dispuesto en el apartado 1 de este artículo, la Administración indemnizará al contratista de los dańos y perjuicios que se le irroguen, incluidos los beneficios futuros que deje de percibir...».

${ }^{7}$ Art. 248.2 a) «Cuando la Administración modifique, por razones de interés público, las condiciones de explotación de la obra».

${ }^{8}$ Si bien la doctrina lo sigue considerando aplicable a todos los contratos públicos. MuÑoz Machado, S., Tratado de Derecho Administrativo y Derecho Público General. Tomo XIII. Contratos 
ciones de la Administración Pública concedente, por su carácter obligatorio para el concesionario determinaren de forma directa la ruptura sustancial de la economía del contrato».

Esta Ley incorpora un nuevo concepto del factum principis que contrasta con la configuración tradicional que había fijado la doctrina y la jurisprudencia, confirmando su reconocimiento excepcional en la práctica. Sin embargo, la limitación del concepto también implica el establecimiento de un espacio específico donde esta figura puede funcionar de forma autónoma y con total separación del resto de técnicas que hasta ahora la habían ensombrecido.

\section{CONFIGURACIÓN TRADICIONAL}

\subsection{Presupuesto del FaCtUM PRINCIPIS: LA CONTRAPOSICIÓN ENTRE EL PRINCIPIO DE RIESGO Y VENTURA DEL EMPRESARIO Y EL PRINCIPIO DEL EQUIVALENTE ECONÓMICO}

Para adentrarnos en el estudio del factum principis debemos partir de una cuestión previa, que es la relación existente entre el principio de riesgo y ventura del empresario y el equivalente económico en la contratación administrativa. Al tratarse, como todas las técnicas de equilibrio, de una manifestación del principio de equivalente económico su apreciación estará condicionada por la inoperatividad del principio de riesgo y ventura del empresario, existiendo entre ambos una relación de tensión y alternancia que hace que se contrapesen mutuamente.

En cualquier actuación que plantee dudas sobre la aplicación de una técnica de equilibrio económico lo primero que hay que comprobar es si ese riesgo queda cubierto por el principio de riesgo y ventura, si así fuera quedaría excluido el principio del equivalente económico de forma automática. La regla general es el principio de riesgo y ventura, según el cual, el empresario asume los riesgos derivados de la ejecución del contrato sin que la Administración quede obligada a compensarle por la mayor onerosidad sobrevenida9. De acuerdo con Muñoz Machado, el principio de riesgo y ventura es una expresión de la inmutabilidad del contrato, en cuya virtud el contratista se obliga a entregar una obra determinada asumiendo necesariamente los imprevistos que puedan ocurrir antes de su entrega definitiva a la Administración ${ }^{10}$.

La jurisprudencia del Tribunal Supremo nos ofrece la siguiente definición: «La configuración de la expresión riesgo como contingencia o proximidad de un dańo y ventura como palabra que expresa que una cosa se expone a la contingencia

del Sector Público, BOE, Madrid, 2018, p. 189: «La obligación de restablecimiento del equilibrio económico del contrato, en los supuestos de factum principis, está expresamente consignada en diversos preceptos de nuestro Derecho positivo que, aunque referidos a concretos contratos nominados, se han considerado extensibles por la doctrina a la totalidad de la contratación administrativa».

9 Ariño Ortiz, G., Teoría del equivalente económico..., ob. cit., p. 123.

${ }^{10}$ Muñoz Machado, S., Tratado de Derecho Administrativo..., ob. cit., p. 182. 
de que suceda un mal o un bien, de todo lo cual se infiere que es principio general en la contratación administrativa, que el contratista, al contratar con la Administración, asume el riesgo derivado de las contingencias que se definen en la Ley de Contratos del Estado y se basan en la consideración de que la obligación del contratista es una obligación de resultados... $\nu^{11}$. Esto implica que, con carácter general, los riesgos que amenacen las expectativas económicas del contratista serán insuficientes para provocar la modificación del contrato, excluyendo cualquier posibilidad de compensación a su favor ${ }^{12}$.

El límite del «riesgo y ventura» es el mantenimiento de la ecuación económico-financiera pactada al comienzo de la relación contractual. Aquí es donde entra en juego el principio del equivalente económico. Como señala Ariño Ortiz, se trata de una garantía del contratista frente a los poderes desorbitados de la Administración que permite la equivalencia honesta entre el beneficio del concesionario y sus responsabilidades ${ }^{13}$. Si no existiera este principio, la Administración podría incumplir sus obligaciones cuando una circunstancia imprevista o injustificada amenazara el contrato, dejando desprotegida a la otra parte contratante, que debería cumplir en todo caso. De acuerdo con la doctrina del Consejo de Estado y la jurisprudencia del Tribunal Supremo, la obligatoriedad de los pactos decaerá cuando el cumplimiento resulte excesivamente oneroso y altere los presupuestos del negocio o sus condiciones, provocando un perjuicio o enriquecimiento injusto a la otra parte, siendo imposible compensarlo por los mecanismos regulares ${ }^{14}$.

En consecuencia, como destaca la doctrina, dos son las premisas a tener en cuenta $^{15}$ :

Primera. La excepcionalidad de la compensación por desequilibrio económico, es decir, no siempre surgirá a cargo de la Administración el deber de compensar al empresario por las circunstancias que ocasionalmente aparezcan y le impidan alcanzar sus objetivos económicos. Si se admitiera de forma ilimitada la Administración podría convertirse en un seguro gratuito que garantizara al concesionario de todos los riesgos eventuales de la empresa, desnaturalizando la institución.

11 STSS 15 de marzo de 2005 (RJ 2005/3194), 14 de mayo (2001/4478) y 22 noviembre (2001/9727), entre otras.

12 García de Enterría, E., «Riesgo y ventura y fuerza mayor en el contrato administrativo», RAP, n. ${ }^{\circ} 2,1950$, p. 88 : «La consecuencia inmediata de que la actividad que conduce al resultado en que la prestación consiste se abstraiga en la determinación contractual, es que la suerte de la onerosidad afecta a la misma carezca de todo efecto para mover el mecanismo del contrato».

${ }^{13}$ Ariño Ortiz, G., Teoría del equivalente económico..., ob. cit., p. 241.

${ }^{14}$ Sentencia del Tribunal Superior de Justicia de Castilla y León, 14 de marzo, y Memorias del Consejo de Estado de los ańos 2014-2015, Imprenta Nacional del Boletín Oficial del Estado, Madrid, 2016, p. 313.

${ }^{15}$ Un análisis detallado de la jurisprudencia en Hernández González, F.L., La Nueva Concesión de Servicios. Estudio del Riesgo Operacional, Thomson Reuters Aranzadi, Navarra, 2018, p. 125. 
Segunda. El carácter tasado de las técnicas de equilibrio económico, es decir, tan solo cabrá el restablecimiento del equilibrio económico cuando estemos ante un supuesto de compensación por ius variandi, factum principis, riesgo imprevisible y fuerza mayor. Las dos primeras son imputables a la Administración, mientras que las restantes son consecuencia de circunstancias ajenas a esta. Tan solo los riesgos ordinarios o inherentes al negocio, incluido el caso fortuito, son de cuenta del contratista y son abarcados por el «riesgo y ventura del empresario $»^{16}$.

\subsection{Características}

El Dictamen 3725/1948, de 3 de noviembre, del Consejo de Estado exige los siguientes requisitos para apreciar un caso de factum principis:

a) Una medida de carácter general.

b) Un acto de autoridad que nazca del poder general de imperium. Esta técnica no funcionará cuando la actuación de la Administración se haya originado por circunstancias ajenas a su poder de decisión.

c) El acto que nazca de la Administración debe tener eficacia bastante para imponerse en la ejecución de los contratos, por lo que exige relación directa de causalidad entre la disposición administrativa y la subida del precio.

d) Debe ser imprevisto y posterior a la adjudicación.

e) Debe ser cierto y especial, no quedarán cubiertos los daños que afecten a la colectividad y constituyan cargas públicas.

f) No debe haber culpa del contratista.

A los presupuestos anteriores es necesario añadir que, para que surja el deber de indemnizar la lesión, la medida general de la Administración debe ser de carácter imprevisible y extraordinario, incorporando nuevos elementos de hecho extraños al contrato que alteren su curso normal. Además, no deben existir otros mecanismos que permitan el resarcimiento del daño en el seno de la relación contractual ${ }^{17}$.

\subsection{Delimitación con otras figuras afines}

Como hemos indicado, el factum principis coexiste con otras técnicas de equilibrio económico como son el ius variandi, la fuerza mayor y el riesgo imprevisible. Estas tres técnicas son autónomas y cuentan con un desarrollo técnico-jurídico

${ }^{16}$ Ariño Ortiz, G., Teoría del equivalente económico..., ob. cit., pp. 162-164.

17 Ariño Ortiz, G. Teoría del equivalente económico..., ob. cit., pp. 261 y 262 y Dictamen del Consejo de Estado núm. 1598/2002, del 31 de octubre. 
profundo que contrasta con el factum principis, que, por el contrario, se encuentra en una posición especialmente vulnerable al compartir notas definitorias con las otras técnicas que ha dado lugar a dudas sobre su utilidad, así como al sistema de compensación aplicable. En efecto, el factum principis comparte con el ius variandi la necesidad de una actuación que emana de la Administración; mientras que comparte con la fuerza mayor y el riesgo imprevisible la nota de la imprevisibilidad.

En primer lugar, el ius variandi requiere una actuación de la Administración que es fruto de la potestad de modificación directa del contrato. Tradicionalmente, lo que ha permitido distinguir el factum principis del ius variandi ha sido el sujeto, es decir, la Administración que da origen a la actuación: si el acto emanaba de la Administración contratante estábamos ante un caso ius variandi; pero si provenía de una Administración distinta sería encuadrable en el factum principis. Las características del ius variandi pueden agruparse de la siguiente forma: a) se trata de una actuación que emana de la Administración Pública contratante; b) se basa en motivos de interés público; y c) afecta de forma directa a una concreta relación contractual.

En segundo lugar, la fuerza mayor constituye un supuesto claramente diferenciable y sobre el que no ha habido discusiones doctrinales más allá del carácter de numerus apertus o numerus clausus de los supuestos que contempla la ley ${ }^{18}$. La Sentencia del Tribunal Supremo de 15 de marzo de 2005 (RJ 2005/3194) destaca las siguientes notas definitorias: a) se refiere a factores de carácter imprevisible y anormales en el desarrollo de las obras; b) imprevisible e inevitable; c) ajenos a la voluntad de las partes y, especialmente, a la conducta del contratista (no puede haber una actuación imprudente por su parte); y d) incidencia negativa en la ejecución contrato provocando la ruptura sustancial del equilibrio económico del contrato.

Finalmente, el riesgo imprevisible es una de las técnicas que más dificultades presenta para distinguirla del factum principis, puesto que la línea divisoria entre una y otra resulta, en ocasiones, difusa. El origen del riesgo imprevisible se encuentra en el arrêt de Gaz de Bordeaux de 30 de marzo de 1916, en el que se pretendía reclamar a la Administración francesa el incremento de los costes de una concesión que había ocasionado la subida del precio del carbón, aumento que se produjo como consecuencia de la ocupación de la mayor parte de las regiones productoras de carbón de Europa continental durante la 1. ${ }^{a}$ Guerra Mundial. El Consejo de Estado francés consideró que el aumento de los costes de producción del gas era tan alto que superaba los límites máximos que pudieron ser tenidos en cuenta por las partes en el momento de firmar el contrato de concesión y que, al darse esas circunstancias extraordinarias, la economía del contrato se había visto totalmente trastocada sin que se le pudiera exigir a la compañía que garantizara el funcionamiento del servicio en las mismas condiciones de origen.

18 García de Enterría, E. y Fernández Rodríguez, T.R., Curso de Derecho Administrativo I..., ob. cit., p. 763: GARCíA DE ENTERRÍA analizó el art. 214.2 LCSP 2007 y se inclinó a favor de su consideración como una lista abierta de supuestos; sin embargo, la jurisprudencia sostiene la posición contraria (STSS 15 de marzo del 2005 y 27 de octubre de 2009) y la Ley actual es claramente restrictiva al reducir su apreciación a los supuestos enumerados en el artículo 239 LCSP 2017. 
Las características del riesgo imprevisible son a) acontecimientos de carácter imprevisible (en sus orígenes se limitaba a las circunstancias de carácter económico, pero con posterioridad se extendió a fenómenos naturales y medidas adoptadas por los poderes públicos); b) el acontecimiento que lo causa debe tener carácter objetivo y tiene que basarse en criterios de racionalidad; c) ajeno a las partes; d) debe provocar la ruptura sustancial de la economía del contrato; y e) opera en ambas direcciones, tanto a favor del contratista como de la Administración ${ }^{19}$.

El hecho de que se trate de acontecimientos imprevisibles y ajenos a las partes, además de que originariamente el riesgo imprevisible exigiera que las circunstancias que provocaran la alteración fueran de índole económica, ha favorecido la confusión entre esta figura y el factum principis ${ }^{20}$.

A pesar de esto, la doctrina ha defendido la autonomía del riesgo imprevisible frente al ius variandi y el factum principis apoyándose en la literalidad del artículo 127.2 b) del Reglamento de Servicios de las Corporaciones Locales de 1955, cuando dice: "Revisará las tarifas y subvención cuando, aun sin mediar modificaciones en el servicio.... ${ }^{21}$, entendiendo que tales modificaciones pueden ser como consecuencia del ius variandi o del factum principis; como categorías diferenciadas del riesgo imprevisible.

\section{FUNDAMENTO}

En un primer momento, la jurisprudencia clásica no acoge el factum principis porque no se podía justificar en un incumplimiento contractual y, por tanto, no cabía una indemnización. La doctrina de la responsabilidad se construía sobre la culpa y la Administración no podía responder de una lesión que se producía en la ejecución del contrato por una medida que no solo se encontraba dentro de sus competencias, sino que había sido acordada de forma legítima y que no contenía

19 Devolvé, P. y Long, M. (coord.), Jurisprudencia Administrativa del Consejo de Estado Francés. Grands Arrêts, BOE, Instituto Nacional de Administración Pública, Madrid, 2015, pp. 251256 y Hernández González, F.L., La Nueva Concesión de Servicios..., ob. cit., pp. 140-142.

${ }^{20}$ La STSJ País Vasco núm. 599/2000, 17 de noviembre (RJC 2001/327), es un fiel reflejo de la confusión existente entre ambas figuras: «La otra se refiere indistintamente a la emergencia de circunstancias sobrevenidas e imprevisibles que determinen la ruptura de la economía de la concesión, -artículo 127.2.2.b) RSCL-, que, como hemos anticipado, se produce por la acción de fuerzas económicas independientes de la voluntad de las partes contratantes o en su caso del denominado "factum principis"... el restablecimiento del equilibrio económico no se traduciría tampoco en una compensación integral de los perjuicios sufridos por el concesionario como en el caso del "ius variandi", sino en un reparto entre concedente y concesionario de los perjuicios imprevisible...».

${ }^{21}$ García de Enterría, E. y Fernández Rodríguez, T.R., Curso de Derecho Administrativo I..., ob. cit., pp. 758 y 759 . 
reflejo alguno de antijuridicidad. Con posterioridad a la Ley de Revisión de Precios de 1945 se reconoce su naturaleza extracontractual ${ }^{22}$.

En la doctrina, cabe destacar dos tesis sobre el fundamento del factum principis: en primer lugar, desde su análisis histórico, Ariño Ortiz lo sitúa en la potestad ordenatoria general de la economía del Estado ${ }^{23}$.

Sin embargo, se debe a los profesores García de Enterría y Fernández Rodríguez la tesis mayoritaria, que parte del reconocimiento de un ámbito de actuación del factum principis que opera en un plano superior a la relación contractual, como manifestación del ejercicio de poderes irrenunciables de la Administración, como pueden ser la potestad expropiatoria o la potestad reglamentaria ${ }^{24}$. Así, la fundamentación del factum principis se apoya en los artículos que regulan la responsabilidad patrimonial de las Administraciones Públicas. De esta forma, cuando los pliegos prevean declaraciones sobre la imposibilidad de repercutir cargas, esta limitación no podrá extenderse a las que surjan en el período de ejecución del contrato como consecuencia del factum principis. En tal caso será necesario indemnizar, aunque no exista cláusula de revisión de precios.

En este sentido, el Dictamen del Consejo de Estado 31/1992, de 13 de febrero, contempla un supuesto en el que el interesado invoca el factum principis apoyándose en los artículos 40 de la Ley de Régimen Jurídico de la Administración del Estado, en el 121 de la Ley de Expropiación Forzosa y, finalmente, en el 106.2 de la Constitución. El Consejo señaló que estos artículos solo serían de aplicación cuando no existiera una relación típica entre la Administración y el afectado que pudiera abarcar el dańo, es decir, cuando el sujeto que sufriera el dańo fuera un tercero frente a las actuaciones de aquella. Sin embargo, la existencia de una relación típica entre Administración y reclamante no excluiría sin más la facultad de reclamar el daño causado, puesto que podría obtenerse a través de las normas reguladoras de la relación entre ambos sujetos. Esto es así porque, en determinados casos, la

22 Albendea Solís, I. y León González, A., «El reequilibrio económico de los contratos», en Gamero Casado, E. y Gallego Córcoles, I. (dirs.), Tratado de Contratos del Sector..., ob. cit., pp. 2295 y 2296.

${ }^{23}$ Ariño Ortiz, G., Teoría del equivalente económico..., ob. cit., p. 263: «Las segundas son manifestación de la potestad ordenatoria general de la economía, de que goza el Estado interventor; son las medidas à la grande orchéstre, tales como devaluaciones monetarias, manejo del tipo de interés, medidas de variación del arancel, cargas sociales y, en general, todas las que supongan alteración directa de las condiciones económicas en que los contratos se ejecutan».

${ }^{24}$ García de Enterría, E. y Fernández Rodríguez, T.R., Curso de Derecho Administrativo, $I, 5 .^{a}$ ed. Civitas, Madrid, 1992, pp. 663 y 664: «... este poder administrativo de alterar contratos, cuando no cabe por sí mismo, como un poder contractual estricto, aparece con toda claridad como la manifestación o incidencia en el cuadro del contrato, o bien del genérico poder de sacrificio de situaciones patrimoniales de que la Administración es titular, de la potestad expropiatoria, aunque esta pueda presentarse aquí y liquidarse al margen del procedimiento expropiatorio ordinario... o bien como expresión del poder reglamentario y su posibilidad de introducir alteraciones en las relaciones jurídicas existentes por vía normativa...». 
existencia de una previa relación jurídica es presupuesto de facto para la efectividad de la responsabilidad extracontractual por factum principis.

De acuerdo con el Consejo de Estado, existe factum principis cuando la Administración está vinculada con un particular y lesiona la economía sinalagmáticamente acordada a través de un acto propio que tiene su origen en el poder de imperium. Por tanto, el fundamento de la indemnización por factum principis es la responsabilidad extracontractual o responsabilidad patrimonial de la Administración ${ }^{25}$.

El Dictamen del Consejo de Estado 1598/2002, de 31 de octubre, diferencia el fundamento de la reclamación de la compensación económica en casos de ius variandi, del factum principis. Siendo la primera de naturaleza y fundamento contractual y la segunda extracontractual, aunque esta se liquide en el seno del contrato. Tal y como se desprende del Dictamen: «La figura del factum principis entraña un sacrificio puro y simple de la posición material que el contrato administrativo precisamente aseguraba» y ello es lo que da origen al deber de compensar.

Por otro lado, la consideración autónoma de la responsabilidad patrimonial como institución aplicable en todos los ámbitos del Derecho, con un régimen jurídico propio y fácilmente comprensible, se convierte en una alternativa que rivaliza con el factum principis para la solución de problemas. Sin embargo, la esencia de esta técnica radica precisamente en su fundamento, que es lo que, paradójicamente, ha garantizado su supervivencia hasta la actualidad. La responsabilidad patrimonial, más allá de desbancar al factum principis, ha sido el recurso por excelencia para resolver los problemas prácticos a los que se refiere esta técnica, lo que se va a ver reflejado en la jurisprudencia. En efecto, en los escasos supuestos en los que se ha aplicado ha sido en base al principio de responsabilidad patrimonial, con la consiguiente indemnización económica propia de esta institución.

En este sentido, tiene especial relevancia la Sentencia del Tribunal Supremo de 20 de noviembre de 1985 (RJ 1985/5566) ${ }^{26}$, que resuelve un recurso de apelación interpuesto contra una Sentencia de la Audiencia Territorial de Cáceres. En un primer momento se impugnó la resolución desestimatoria de la Dirección Provincial del Instituto Nacional de Salud de Badajoz sobre la procedencia del incremento de las tarifas del contrato de gestión de servicio público para la prestación del servicio de ambulancia por el aumento del precio de la gasolina, que era consecuencia de varias órdenes del Ministerio de Hacienda de 1980 y 1981. La sentencia de instancia consideró este supuesto un caso de factum principis por tratarse de medidas administrativas ajenas al contrato, pero que repercutían indirectamente sobre la relación contractual, provocando un aumento de la onerosidad en perjuicio del contratista. La Audiencia Territorial justificó las consecuencias del factum principis en la responsabilidad objetiva de la Administración, aunque se liquide en el seno del contrato. Y, por su parte, el Tribunal Supremo confirmó la decisión de la Audiencia y,

25 Dictámenes núm. 46172, de 10 de mayo, y 46886, de 4 de octubre de 1984.

${ }^{26}$ En el mismo sentido destaca la Sentencia del Tribunal Supremo de 2 de diciembre de 1985 (RJ 1985/6511). 
finalmente, el derecho del prestatario del servicio a percibir una indemnización que atendiera al daño individualizado, con independencia de la existencia o no de una cláusula de revisión de precios.

De esta manera, cuando el Tribunal Supremo ha acudido al principio de responsabilidad patrimonial para solventar las controversias ha dado lugar a una indemnización económica. Esta modalidad de resarcimiento es característica de esta institución en virtud de lo dispuesto en el artículo 34 de la Ley 40/2015, de Régimen Jurídico del Sector Público, aunque excepcionalmente se permitan compensaciones en especie (art. 34.4). Todo lo anterior contrasta con la diversidad de mecanismos de compensación que reconoce la Ley de Contratos del Sector Público actual para todas las técnicas de equilibrio económico, como se verá más adelante.

\section{EL MANTENIMIENTO DEL EQUILIBRIO ECONÓMICO EN LA LEY DE CONTRATOS DEL SECTOR PÚBLICO DE 2017}

La Ley 9/2017, de 8 de noviembre, de Contratos del Sector Público transpone las Directivas del Parlamento Europeo y del Consejo 2014/23/UE y 2014/24/ UE, de 26 de febrero de 2014, y regula el mantenimiento del equilibrio económico para la concesión de obras y de servicios públicos en los artículos 270 y 290 respectivamente, manteniendo prácticamente la misma redacción en ambos preceptos.

Previamente, cabe destacar que el legislador reconoce en el artículo 257 b) el derecho del concesionario al mantenimiento del equilibrio económico de la concesión conforme a las reglas contenidas en el artículo 270. En el mencionado precepto se desarrolla el deber de mantener la ecuación financiera de la concesión en los términos originariamente pactados para su adjudicación, para lo que habrá que tener en cuenta el interés general y el interés del concesionario. A continuación, se prevén los supuestos en los que es obligatorio el restablecimiento del equilibrio, es decir, las cuatro técnicas de equilibrio económico que abordaremos inmediatamente.

En primer lugar, el artículo 270.2, a) prevé el equilibrio económico del contrato «cuando la Administración realice una modificación de las señaladas en el artículo 262", en clara alusión al ius variandi ${ }^{27}$. No obstante, las circunstancias que permiten la modificación de los contratos están reguladas en los artículos 203 y ss. de la Ley, que transponen los arts. 72 de la Directiva 2014/24 y 43 de la Directiva 2014/23. Sucede, sin embargo, que estas últimas incorporan un con-

27 El art. 262.1 dispone que «el órgano de contratación podrá acordar, cuando el interés público lo exija y si concurren las circunstancias previstas en esta Ley, la modificación de las obras, así como su ampliación, procediéndose, en su caso, a la revisión del plan económico-financiero al objeto de acomodarlo a las nuevas circunstancias». En la misma línea, el art. 261.1 recoge, entre las prerrogativas y derechos de la Administración, en la letra b): «Modificar unilateralmente los contratos por razones de interés público debidamente justificadas, de acuerdo con lo previsto en esta Ley»; y d) «Acordar la resolución de los contratos en los casos y en las condiciones que se establecen en los artículos 279 y $280 »$. 
cepto amplio, comprensible tanto del ius variandi como del riesgo imprevisible (lo mismo hace el art. 290 para las concesiones de servicios) ${ }^{28}$. Es así como la letra b) del artículo 205.2 dispone que se podrá modificar el contrato cuando «se derive de circunstancias sobrevenidas y que fueran imprevisibles en el momento en que tuvo lugar la licitación del contrato... $\nu^{29}$. Para su apreciación son exigibles tres condiciones: a) que se trate de una circunstancia imposible de prever para una Administración diligente; b) que no se altere la naturaleza global del contrato; y c) que la alteración de la cuantía no supere, aislada o conjuntamente con otras modificaciones, el $50 \%$ del precio inicial.

En segundo lugar, los artículos 270.2 , b) y 290.4 , b) contemplan el factum principis como una figura independiente del ius variandi y del riesgo imprevisible. Esta apreciación es relevante porque, aunque la configuración actual tiende a asimilarlo al ius variandi al equipararlas en función del origen de la mayor onerosidad por ser actuaciones que emanan de la Administración, la redacción no genera confusión sobre la autonomía de cada una de ellas. También es llamativo que se contemple el factum principis y la fuerza mayor en apartados distintos, dado que en las dos legislaciones anteriores se recogían conjuntamente. Esta nueva configuración del factum principis será analizada con detenimiento en el epígrafe siguiente, si bien cabe anticipar de conformidad con los artículos mencionados que se configura como una actuación de carácter obligatorio que emana de la Administración Pública contratante y que conlleva la ruptura sustancial de la economía del contrato.

En cuanto a la fuerza mayor, tan solo se admitirá en los casos contemplados en el artículo $239^{30}$ de la Ley, cuando se produzca la ruptura sustancial de la ecuación financiera de la relación contractual. Esta es la única técnica que ha permane-

${ }^{28}$ Manent Alonso, L., «Tipología de contratos (II): Los contratos de concesión de obras y servicios", en Mestre Delgado, J.F. y Manent Alonso, L. (dirs.), La Ley de Contratos del Sector Público Ley 9/2017, de 8 de noviembre. Aspectos novedosos, Tirant lo blanch, Valencia, 2018, p. $174 \mathrm{y}$ nota núm. 79: la doctrina pone de manifiesto la sorpresa que causó el hecho de la que la Directiva 2014/23 no regulara en lo más mínimo el mantenimiento del equilibrio de la concesión, quedando en manos de la LCSP 2017 despejar las dudas sobre esta materia. Como señala el autor, el Consejo Europeo decidió no incorporar el mantenimiento del equilibrio financiero en su orientación general de 26 de noviembre de 2012 a la propuesta de Directiva en el ámbito de la adjudicación de contratos de concesión porque consideró que esta finalidad podía lograrse a través del régimen de modificaciones previsto en el artículo 43 de la Directiva 2014/23.

${ }_{29}$ Manent Alonso, L., «Tipología de contratos (II): Los contratos de concesión de obras y servicios», en Mestre Delgado, J.F. y Manent Alonso, L. (dirs.), La Ley de Contratos del Sector Público..., ob. cit., pp. 176-178: El autor considera esta previsión del legislador como el primer intento de positivación que se hace en una ley estatal, aunque entiende que se ha realizado sin respetar los márgenes que la jurisprudencia había definido hasta ahora por recogerlo junto con el ius variandi. La previsión de ambas figuras conjuntamente implicaría la aplicación de las mismas reglas sobre equilibrio económico.

${ }^{30}$ Art. 239.2: «Tendrán la consideración de casos de fuerza mayor los siguientes: a) Los incendios causados por la electricidad atmosférica b) Los fenómenos naturales de efectos catastróficos... c) Los destrozos ocasionados violentamente en tiempo de guerra, robos tumultuosos o alteraciones graves de orden público». 
cido prácticamente inalterada desde la Ley de Contratos de las Administraciones Públicas de 1965. Los problemas que tradicionalmente se planteaban en torno al carácter abierto o cerrado de la lista de supuestos son resueltos por la jurisprudencia, que sostiene una interpretación restrictiva sobre esta posibilidad en coherencia con la propia redacción del texto legal ${ }^{31}$.

Por otro lado, los artículos 270.3 y 290.5 recogen diversas formas de compensación ${ }^{32}$, que van más allá de la mera indemnización, propia del principio de responsabilidad patrimonial, como pueden ser la modificación de tarifas, la modificación de la retribución a abonar por la Administración, la reducción del plazo concesional, cualquier modificación de las cláusulas de contenido económico, así como la ampliación del plazo. Cabe tener en cuenta que la ampliación del plazo concesional o prórroga de la concesión es un mecanismo que se reconoce exclusivamente para los casos de factum principis y fuerza mayor ${ }^{33}$.

Aunque la ley se dedica a establecer las diversas modalidades de compensación, en ningún momento determina cuál es el sistema de compensación aplicable a cada técnica de equilibrio económico. La legislación se limita a precisar cómo pagar al contratista (lo que es común a todas las técnicas), en vez de determinar cómo se restablece el equilibrio del contrato, lo que es imprescindible para que el principio de equilibrio económico se desenvuelva adecuadamente y que cobra aún más relevancia si tenemos en cuenta que no todas las técnicas se compensan de la misma forma. Sin perjuicio del análisis que se hace sobre esta cuestión, cabe destacar que existen dos sistemas de compensación: uno que persigue la reposición del contratista a la posición inicialmente pactada con la compensación integral del daño; y otra que, por el contrario, exige la compartición del daño entre las partes del contrato.

A pesar de las novedades que incorporan las Directivas sobre contratación, no se incluye ninguna especialidad relativa al mantenimiento del equilibrio económico del contrato. Esto no quiere decir que los cambios comentados anteriormente no influyan sobre el ejercicio del principio de equilibrio económico; de hecho, la redacción actual adolece de una falta de armonización que despierta dudas sobre el funcionamiento de las técnicas, especialmente sobre el ius variandi y el riesgo imprevisible.

31 Muñoz Machado, S., Tratado de Derecho Administrativo..., ob. cit., p. 184.

${ }^{32}$ Esta previsión se complementa con el artículo 127.2.2. ${ }^{\circ}$ RSCL: «a) compensará económicamente al concesionario por razón de las modificaciones... b) revisará las tarifas y subvención...».

${ }^{33} \mathrm{El}$ art. 270.3 requiere para prorrogar la concesión que «la retribución del concesionario proviniere en más de un 50 por ciento de tarifas abonadas por los usuarios, podrá prorrogarse el plazo de la concesión por un período que no exceda de un 15 por ciento de su duración inicial», el 290.5 tan solo exige que el plazo no supere el $15 \%$ de su duración inicial. 


\section{LÍMITES A LA APLICACIÓN DEL FACTUM PRINCIPIS: EXCLUSIÓN DE LOS ACTOS DE UNA ADMINISTRACIÓN DISTINTA DE LA CONCEDENTE Y DEL PODER LEGISLATIVO}

La nueva Ley resuelve dos cuestiones polémicas que tradicionalmente habían caracterizado el factum principis. La primera de estas cuestiones tiene que ver con el origen del acto de imperium, mientras que la segunda tiene que ver con la naturaleza del acto.

\subsection{Actuaciones de una Administración distinta de la CONCEdente}

El artículo 248.2, b) de la Ley 13/2003 exigía el restablecimiento del equilibrio económico de la concesión cuando «... actuaciones de la Administración determinaran de forma directa la ruptura sustancial de la economía de la concesión»; la expresión "Administración» permitía englobar tanto actuaciones de la Administración concedente como de otras distintas.

Un ejemplo a favor de esta consideración viene recogido en el Informe 61/08 de la Junta Consultiva de Contratación Administrativa del Estado de 31 de marzo de $2009^{34}$, en el que la JCCA identifica como factum principis una alteración impuesta por una autoridad ajena a la relación contractual. En el supuesto, el Ayuntamiento de Mijas suscribió una concesión desde el año 1996 hasta 2010, pero en 2006 el concesionario solicita al Ayuntamiento la ampliación del plazo concesional y el incremento del canon como consecuencia de nuevas exigencias ambientales. El origen del desequilibrio que la propia JCCA califica posteriormente de factum principis radica en un acto administrativo de la Junta de Andalucía que, a su vez, se dictó como consecuencia de las previsiones contenidas en la Ley 16/2002 de Prevención y Control de la Contaminación.

La posibilidad de extender el factum principis a cualquier Administración no solo se justificaba en la redacción prevista en la Ley 13/2003, sino en el propio fundamento de esta técnica. El principio de responsabilidad objetiva de la Administración permite entender que cualquier medida imperativa y obligatoria que reúna los requisitos propios del factum principis podría dar lugar a una indemnización ${ }^{35}$.

En sentido opuesto se manifestó el Consejo de Estado en el Dictamen número 1030/2015, de 21 de enero, donde valoró cautelosamente esta cuestión por el riesgo que supone para la Administración contratante poder convertirse en garante frente a terceros de la posición jurídica inicial del concesionario, especialmente si los actos son realizados por otras Administraciones Públicas que actúan amparadas por sus propias competencias.

${ }^{34}$ Otro ejemplo es el contenido en la STS 2 diciembre de 1985 (RJ 1985/6511).

35 Hernández González, F.L., La Nueva Concesión de Servicios..., ob. cit., p. 147. 
En dicho Dictamen, el Consejo de Estado trae a colación la Sentencia del Tribunal Supremo de 16 de mayo de 2011 (RJ 2011/4351), en la que la demandante pretende el restablecimiento del equilibrio económico por concurrir circunstancias imprevisibles en el momento en que presentó la oferta y que le impidieron que la ejecución del contrato se desarrollara con normalidad. Tal y como explica el Consejo de Estado, la concesionaria construyó una autopista de peaje (AP-41), pero esta vio limitada sus funciones por dos motivos:

a) Porque se produjo un desdoblamiento de una autopista autonómica con la intención de mejorarla que redujo el tráfico de la AP-41.

b) Porque en el momento en que se construyó la AP-41 estaba previsto construir otra autopista de forma simultánea que se encargaría de desviar el tráfico y garantizar su funcionamiento, pero nunca se construyó por no cumplir los requisitos medioambientales.

La concesionaria invoca el factum principis y considera que no ha habido una coordinación entre Administraciones, por lo que finalmente la Administración General del Estado debe responder por los daños ocasionados.

El Tribunal Supremo negó el derecho del concesionario al restablecimiento del equilibrio económico de la concesión en el primer caso porque no puede responsabilizarse a la Administración del desequilibrio que pudieran causar las actuaciones de otras Administraciones en el ejercicio de sus competencias. En cambio, en el segundo supuesto, el Tribunal resolvió acordando el reequilibrio económico al considerar que la entrada en servicio de la otra autopista era fundamental para el planteamiento de la AP-41, siendo su construcción un evento hipotético y futuro que rompía la ecuación financiera del contrato.

Cobra especial relevancia de cara a la cuestión que tratamos una de las conclusiones a las que llega el Consejo de Estado, en cuya virtud los actos de autoridad que emanen de la Administración contratante, siempre que reúnan los presupuestos necesarios para ello, consistirán un supuesto de factum principis. En cambio, las actuaciones que provengan de Administraciones distintas de la concedente y desequilibren las prestaciones contractuales se encauzarán por la teoría de la imprevisión ${ }^{36}$.

36 «En el caso presente, se puede avanzar que no existen fundamentos jurídicos suficientes para sostener que la reducción del volumen del tráfico [...] puede ser considerada un supuesto de responsabilidad administrativa por factum principis. La aplicación de esta teoría únicamente resulta viable cuando la medida que da lugar al desequilibrio contractual procede de la Administración concedente y que reconducen los desequilibrios generados como consecuencia de la adopción de la medida en cuestión por una administración distinta a la doctrina del riesgo imprevisible...». 
El profesor Arińo Ortiz se pronunció, en un primer momento, en contra de esta posibilidad, por la inmunidad natural que caracteriza a la ley, apoyándose en la jurisprudencia del Tribunal Supremo de la época, que defendía la inexigibilidad de resarcimiento por el cumplimiento de las leyes. No obstante, en contra de su posición inicial, el autor terminó asumiendo que los principios de nuestro ordenamiento animan a resolver que no se debe excluir la indemnización salvo que una ley así lo establezca. Esta interpretación la realizó a la luz de los principios inspiradores de la Ley de Expropiación Forzosa, en cuya virtud toda privación singular permite exigir responsabilidad, aunque esta sea creada por ley ${ }^{37}$.

En este sentido, cabe destacar nuevamente el informe de la JCCA 61/08 en el que se reconoce la existencia del factum principis porque existe una medida de carácter obligatorio y general adoptada fuera del ámbito contractual que perjudica al contratista. Además, el origen se encuentra en una norma jurídica que entra en vigor durante la concesión (Ley 16/2002, de 1 de julio) y de la que se deriva la obligación de realizar determinadas obras de adaptación de las instalaciones ${ }^{38}$.

Por su parte, el Dictamen del Consejo de Estado 1598/2002, mencionado anteriormente, contempla un supuesto en el que Telefónica reclama una compensación por ruptura del equilibrio económico del contrato como consecuencia, entre otras cosas, de la supresión de su derecho a la prestación del servicio en régimen de monopolio. Esta restricción tuvo su origen en la aprobación de la Ley 12/1997, de 24 de abril, de Liberalización de las Telecomunicaciones, y la Ley 11/1998, de 24 de abril, General de Telecomunicaciones.

Telefónica no fundó la reclamación en un supuesto de factum principis, pero el Consejo de Estado lo valoró igualmente porque consideró que la aprobación de la norma podía dar lugar a la aparición de esta figura, bien por la aplicación del principio de responsabilidad del Estado legislador, o bien por constituir una expropiación legislativa. Finalmente, rechazó esta posibilidad por entender que la liberalización no era consecuencia del ejercicio de una potestad de imperium de la Administración española, sino de las exigencias de Derecho comunitario, que, al fin y al cabo, son una proyección de la condición de España como Estado miembro de la Unión Europea. En ningún momento se deduce del Dictamen que la imposibilidad de apreciar el factum principis dependa del carácter legislativo del acto que origina el desequilibrio contractual.

${ }^{37}$ Ariño Ortiz, G., Teoría del equivalente económico..., ob. cit., p. 269. Destaca las SSTS 25 de julio de 1917 y 12 de febrero de 1909.

38 En el citado Dictamen se establece lo siguiente: «En el presente caso, podemos considerar que existe una medida de carácter general cual es la exigencia de una autorización para la actividad cuya obtención es exigida "ex novo" en virtud de lo dispuesto en una nueva norma jurídica (la Ley $16 / 2002$, de 1 de julio), y de la que se deriva obligatoriamente la realización de determinadas obras de adaptación de las instalaciones». 
Una posición favorable es la que mantiene también, en la doctrina más reciente, Vázquez Lacunza, al afirmar que cualquier medida que cumpla con las condiciones para apreciar el factum principis, con independencia de su origen legal o administrativo, dará lugar a la compensación del adjudicatario. Para ello, se apoya nuevamente en la responsabilidad patrimonial, salvo que la propia ley lo excluya expresamente ${ }^{39}$.

\subsection{La Solución de La Nueva Ley de Contratos}

En cuanto a las dos cuestiones expuestas anteriormente, la LCSP 2017 disipa cualquier duda al respecto cuando circunscribe las actuaciones que pueden dar lugar al factum principis exclusivamente a aquellas que provengan de la Administración Pública concedente, excluyendo cualquier actuación no solo de otras Administraciones Públicas ajenas a la relación contractual, sino de otros poderes públicos en general.

Los artículos 270.4 y 290.6 establecen un derecho de desistimiento a favor del contratista cuando el cumplimiento resulte extraordinariamente oneroso para el concesionario por alguna de estas circunstancias:

a) La aprobación de una disposición general por una Administración distinta de la concedente con posterioridad a la formalización del contrato.

b) Cuando el concesionario deba incorporar a las obras o explotación, como consecuencia de una obligación legal o contractual, avances técnicos que la mejoren notoriamente y cuya disponibilidad se haya producido con posterioridad a la formalización del contrato.

Como se puede comprobar, el legislador ha limitado el concepto que tradicionalmente había establecido la doctrina y la jurisprudencia, incorporando así las tendencias jurisprudenciales más actuales a la ley. De esta forma, la actuación de una Administración distinta de la concedente no podrá dar lugar a una compensación por factum principis; $\mathrm{y}$ tampoco como consecuencia de la aplicación legal o contractual de la denominada cláusula de progreso $0^{40}$.

Ambas cuestiones se dilucidan al margen del restablecimiento del equilibrio económico del contrato. En este sentido, el art. 270.2, tras reconocer el ius variandi, el riesgo imprevisible y el factum principis, establece lo siguiente: «Fuera de los casos previstos en los casos anteriores, únicamente procederá el restablecimiento del equilibrio económico del contrato cuando causas de fuerza mayor determinaran de forma

39 VÁzquez Lacunza, E., El equilibrio en los contratos de servicios, Thomson Reuters Aranzadi, Navarra, 2016, pp. 266.

40 Hernández González, F.L., La Nueva Concesión de Servicios..., ob. cit., pp. 337 y 338; y Manent Alonso, L., «Tipología de contratos (II): Los contratos de concesión de obras y servicios», en Mestre Delgado, J.F. y Manent Alonso, L (dirs.), La Ley de Contratos del Sector Público..., ob. cit., p. 176. Menciona la STS 11 de mayo de 2011. 
directa la ruptura sustancial de la economía del contrato...». Los supuestos mencionados en el apartado cuatro del mismo artículo no dan lugar a una compensación porque no provocan la ruptura de la ecuación financiera del contrato; además, en el caso de que el concesionario decida desistir el contrato amparándose en alguna de tales circunstancias no tendrá derecho a indemnización alguna.

\section{COMPENSACIÓN}

Otro de los problemas al que se enfrenta el factum principis desde sus orígenes es el relativo al sistema de compensación, precisamente, por la posición intermedia que ha mantenido entre el ius variandi y el riesgo imprevisible. La importancia de esta cuestión se justifica en la finalidad misma del mantenimiento del equilibrio económico, que persigue el restablecimiento de la ecuación financiera cuando esta se rompe de forma sustancial. El restablecimiento solo puede lograrse a través de la compensación adecuada; por ello, la claridad sobre el sistema aplicable determinará la capacidad de la técnica para cumplir con el cometido que se le encomienda.

La primera de estas fórmulas se conoce como compensación integral implica, como dice García de Enterría, el abono de los perjuicios causados, es decir, el daño emergente y el lucro cesante, hasta el restablecimiento de la ecuación financiera del contrato, tal y como ocurre con el ius variandi $i^{41}$. El segundo sistema es propio del riesgo imprevisible e implica la compartición del gasto, esto es, el reparto proporcional y razonable de las pérdidas entre Administración y contratista.

Tradicionalmente, la doctrina mayoritaria ha considerado que la compensación derivada del factum principis no tiene el mismo carácter que la del ius variandi, por lo que no tiene carácter integral. Ariño Ortiz justificó esa diferencia en que, en el caso del factum principis hablamos de indemnización, lo que supone que el daño causado es antijurídico y debe repararse. Ocurre lo contrario con el ius variandi, donde hablamos de compensación y esto implica que el daño está justificado, pero genera al favor del contratista el derecho a percibir el equivalente.

Según el autor, la indemnización no lleva implícita la idea de compensación total, pudiendo incluir el pago de un precio superior o inferior al valor de la prestación en función del daño causado; en cambio, en la compensación integral se hace referencia a la idea de precio y la cuantía a pagar será exactamente la correspondiente a la prestación ${ }^{42}$.

${ }^{41}$ Ariño Ortiz, G., Teoría del equivalente económico..., ob. cit., p. 245; y García de Enterría, E. y Fernández Rodríguez, T.R., Curso de Derecho Administrativo I..., ob. cit., p. 753.

${ }_{42}$ Ariño Ortiz, G., Teoría del equivalente económico..., ob. cit., pp. 267 y 268: el autor sostuvo originariamente dos posiciones contrapuestas, en un primer momento y a partir de la interpretación del artículo 57 del Reglamento de las Corporaciones Locales de 1953 y la Ley de Revisión de Precios de 1945 consideró dudoso el carácter integral de la indemnización por factum principis, viendo razonable la posibilidad de que Administración y contratista compartieran el daño. Posteriormente cambió de postura, apoyándose en el artículo 80 LCAP, que contemplaba como causa de 
La jurisprudencia del Tribunal Supremo es un fiel reflejo de esta controversia, existiendo pronunciamientos en los que se ha equiparado el factum principis al ius variandi y otros casos en los que se ha asemejado al riesgo imprevisible, con las consecuencias que ello conlleva en el ámbito de la compensación.

Cabe mencionar, a modo de ejemplo, la Sentencia del Tribunal Supremo de 25 de abril de 1986 (RJ 2081/1986), que en su tercer fundamento jurídico marca una separación entre las consecuencias que conlleva el ius variandi y el factum principis de los casos de riesgo imprevisible. En las primeras dos figuras la Administración tiene el deber de indemnizar al contratista el daño emergente y el lucro cesante para restituir la retribución del concesionario a las condiciones inicialmente pactadas, al contrario que en el riesgo imprevisible, cuya compensación persigue el mantenimiento del servicio a través de la distribución proporcional y razonable de las pérdidas entre ambas partes contratantes.

En sentido contrario, se encuentra la Sentencia del Tribunal Supremo de 9 de octubre de 1987 (RJ 1987/8326), que confirma que la teoría del equilibrio económico de la concesión administrativa que se fundamenta sobre el principio de igualdad proporcional entre las ventajas y cargas de la concesión tiene un doble alcance, uno más limitado que abarca exclusivamente el factum principis y otro más amplio que incluye, además, el riesgo imprevisible.

La posición jurisprudencial mayoritaria determina el sistema de compensación en función del origen de la mayor onerosidad, partiendo de la lectura del artículo 127.2,2. ${ }^{\circ}$ del Reglamento de Servicios de las Corporaciones Locales de $1955^{43}$ :

a) En los casos en los que la alteración sea consecuencia de modificaciones directas (ius variandi) o indirectas (factum principis) provocadas por la Administración se deberá devolver al concesionario a las condiciones inicialmente pactadas, indemnizando tanto el daño emergente como el lucro cesante. Esta tendencia encuentra su apoyo en la LCSP 2017, puesto que, aunque la configuración del factum principis encuentra más limitaciones que en legislaciones anteriores, no deja de perfilar un concepto más preciso y cercano al ius variandi que al riesgo imprevisible, inclinándose hacia el sistema de compensación integral.

b) En los casos en que el desequilibrio sea ocasionado por causas sobrevenidas e imprevisibles que, siendo ajenas a la conducta de las partes, comprometen

resolución aquellos casos en los que la explotación del servicio fuera imposible por acuerdos adoptados por la Administración con posterioridad al contrato, concediéndose en tal caso una indemnización que abarcaba tanto el daño emergente como el lucro cesante.

${ }^{43}$ Art. 127.2: «La Corporación concedente deberá: $2^{\circ}$ Mantener el equilibrio financiero de la concesión, para lo cual: a) compensará económicamente al concesionario por razón de las modificaciones que le ordenare introducir en el servicio y que incrementaren los costos o disminuyeren la retribución; y b) revisará las tarifas y subvención cuando, aun sin mediar modificaciones en el servicio, circunstancias sobrevenidas e imprevisibles determinaren, en cualquier sentido, la ruptura de la economía de la concesión». 
el servicio público se distribuirán las pérdidas entre ambos de forma proporcional y razonable ${ }^{44}$.

\section{CONCLUSIÓN}

La nueva Ley de contratos del sector público consagra expresamente la figura del factum principis como técnica de equilibrio económico del contrato, diferenciada del ius variandi, del riesgo imprevisible y de la fuerza mayor. No obstante, se reduce su tradicional ámbito de aplicación, al restringirla exclusivamente a las actuaciones derivadas de la Administración contratante, lo que no deja de ser cuestionable.

Si bien el texto legal viene a reforzar su consolidada posición en el ordenamiento jurídico como técnica autónoma de equilibrio económico de las concesiones, la regulación vigente sigue siendo insuficiente en muchos aspectos (como el relativo al sistema de compensación). Los estrictos límites a los que se ve constreñida y la falta de precisión pueden perpetuar que el factum principis siga estando a la sombra de otras técnicas, especialmente del riesgo imprevisible, como ha sucedido hasta ahora; y que su aplicación práctica siga siendo algo meramente testimonial.

Recibido: 06-01-2020; ACEPTADo: 14-02-2020

${ }^{44}$ Hernández González, F.L., La Nueva Concesión de Servicios..., ob. cit., p. 151. 


\title{
REFLEXIONES SOBRE LA EVOLUCIÓN LEGISLATIVA Y JURÍDICA DE LOS DERECHOS DE LAS MUJERES EN ESPAÑA: DESDE LA SEGUNDA REPÚBLICA HASTA LA ACTUALIDAD
}

\author{
Dan Stanforth \\ University of Denver \\ Aurelio Santana Rodríguez \\ Universidad de La Laguna \\ José Andrés Salgado Fernández \\ Doctor en Derecho \\ Letrado de la Administración de Justicia-Tribunal Superior de Justicia de Galicia
}

\section{RESUMEN}

Este trabajo ofrece un análisis detallado de los desarrollos legislativos y judiciales con respecto a los derechos de las mujeres en España desde la Segunda República hasta la actualidad. Se examinan los beneficios y consecuencias socioeconómicos y humanos de dicha legislación. Además, se presenta un análisis comparativo, tanto desde la perspectiva cultural como legislativa, para agregar contexto global a los cambios legislativos y judiciales pertinentes.

Palabras clave: los derechos de las mujeres, legislación, internacional, judicial.

\section{REFLECTIONS ON THE LEGISLATIVE \\ AND JUDICIAL EVOLUTION OF WOMEN'S RIGHTS IN SPAIN: FROM THE SECOND REPUBLIC TO THE PRESENT}

\begin{abstract}
This paper delivers a detailed analysis of the key legislative and judicial developments regarding women's rights in Spain from the Second Republic to the present. The socioeconomic and human benefits and consequences of said legislation are examined. Furthermore, a comparative analysis, from both cultural and legislative perspectives, is presented to add global context to the pertinent legislative and judicial changes.

KEYwORDS: women's rights, legislation, international, judicial.
\end{abstract}




\section{LA DESIGUALDAD JURÍDICA DE LA MUJER EN EL DERECHO ESPAÑOL TRAS EL FIN DE LA GUERRA CIVIL}

\subsection{INTRODUCCIÓN}

El punto de partida, para un preciso análisis del objeto de estudio y de su evolución, desde el final de la experiencia republicana hasta el final de la segunda década del régimen franquista, los años cincuenta del siglo $\mathrm{xx}$, debe ser doble: de una parte, la visión sucinta de la situación jurídica de la mujer durante la Segunda República, tanto desde el punto de vista constitucional como del legislativo; y de otra parte, la descripción y análisis de las transformaciones que vinieron como consecuencia de la guerra civil y la llegada de un nuevo régimen político introductor de un planteamiento específico, peculiar pero completamente discriminatorio, sobre los derechos de la mujer.

Ahora bien, de lo que no cabe duda es de que, vista la normativa de la época, la situación jurídica de la mujer, que sufrió una pérdida de derechos en el tránsito de régimen político desde la República hasta la dictadura del general Franco, puede definirse al menos como perjudicial tanto desde la restricción objetiva de sus derechos (también los de los hombres aunque, como se verá, en menor medida) como desde el mantenimiento de la mujer en un papel de inferioridad y sujeción con respecto al hombre. Tanto una como otra circunstancia deben ser vistas de todas formas teniendo en cuenta una doble consideración: el régimen franquista fue limitador de derechos para todas las personas, y no solo para las mujeres, al tratarse de un régimen autoritario y no democrático y poco o nada contemplativo en materia de derechos (si se hace la referencia principalmente a los llamados derechos políticos en su versión de derechos fundamentales y libertades públicas); y, además, fue especialmente severo en cuanto a la situación de la mujer en todos los ámbitos de su vida, y no solo el jurídico, resultando de todo punto significativo esto en el mundo de las normas, pues las que se dictaron fueron muy claras al limitar sus derechos y, en el caso de la mujer casada, al fijar con absoluta precisión su sometimiento jurídico al marido.

No cabe duda de que la instauración de un nuevo sistema político y constitucional en 1931, con el fin de la vigencia de un régimen político constitucionalmente monárquico por otro constitucionalmente republicano, alteró, como en tantos otros aspectos de la vida espańola de la época, el campo de los derechos de las mujeres. Es cierto que en esos momentos estaba anclada en España, como en los países del entorno, una tradición de discriminación contra la que había empezado a lucharse en los países de los dos bordes del Atlántico Norte a lo largo de las primeras décadas del siglo $\mathrm{xx}$, si bien es cierto que, en buena parte de los casos, la igualdad se quedó en el plano político, al concederse en varias de esas naciones a las mujeres los derechos de sufragio activo y pasivo (véase como ejemplo la enmienda XIX a la Consti- 
tución estadounidense, que aprobó el voto femenino en $1920^{1}$ ), pero sin que realmente se acometiera una verdadera equiparación de derechos en todos los ámbitos de la vida, tarea que con toda seguridad vino frenada por los acontecimientos que desembocaron en la Segunda Guerra Mundial, y que pospusieron las tareas legislativas de verdadera igualdad hasta la década de los sesenta.

Instaurada la República, habiendo tomado el poder, mediante elecciones, unos nuevos grupos políticos de corte más progresista, se acometió rápidamente, previo el correspondiente y necesario proceso electoral, la redacción de una nueva Constitución, a finales del propio año 1931. No había duda respecto de las mujeres y sus derechos: la Segunda República abogaba claramente por la igualdad y el fin de las discriminaciones de todo tipo, por lo que se promovió el fin de las restricciones de toda clase por razón de sexo. La declaración de principios en relación con la tónica de actuación general del nuevo régimen político va a ser la disposición incluida en la Constitución republicana en su artículo 25, que, rompiendo una arraigada tradición histórica y abriendo un nuevo camino, prohibió que el sexo sirviera de fundamento de cualquier privilegio jurídico («No pueden ser fundamentos de privilegio jurídico: la naturaleza, la filiación, el sexo, la clase social, la riqueza, las ideas políticas ni las creencias religiosas»).

A partir de ahí, la primera determinación tomada por la Segunda República que afectaba directamente, por el radical seguimiento de la idea de igualdad, a la situación jurídico-privada de la mujer (en este caso, y en parte, también a la del hombre) vino de la mano de la propia Constitución de 1931, que, en relación con el diseño constitucional del matrimonio, dispuso en su art. 43 tanto que «el matrimonio se funda en la igualdad de derechos para ambos sexos» como que «el matrimonio podrá disolverse por mutuo disenso o a petición de cualquiera de los cónyuges, con alegación en este caso de justa causa $»^{2}$. Y como derivación de esta proclama constitucional, se procedió más tarde a la aprobación tanto de la Ley de matrimonio civil de 28 de junio de 1932 como a la de la anterior Ley de divorcio de 2 de marzo del mismo año. En cuanto a la primera, es importante destacar que, además de ser terminante en cuanto a que no admitía más que la forma civil de matrimonio, dispuso que la celebración del matrimonio se sujetara al artículo 100 del Código civil, pero sin la lectura del artículo 57, que disponía la obediencia de la mujer al marido, lo que debió entenderse como una derogación tácita. Y, por otra parte, la Ley de divorcio, que procedió a su regulación desde el más absoluto respeto a la igualdad de los cónyuges en todo momento, dispuso ya en su artículo 1 que el divorcio decretado por sentencia firme de los Tribunales civiles disuelve el matrimonio cualquiera que

1 «The right of citizens of the United States to vote shall not be denied or abridged by the United States or by any State on account of sex. Congress shall have power to enforce this article by appropriate legislation».

2 Además, en el propio artículo 43 se establecía que «... Los padres tienen para con los hijos habidos fuera del matrimonio los mismos deberes que respecto de los nacidos en él... No podrá consignarse declaración alguna sobre la legitimidad o ilegitimidad de los nacimientos, ni sobre el estado civil de los padres, en las actas de inscripción, ni en filiación alguna». 
sea la forma de su celebración, además de permitir a los cónyuges contraer nuevo matrimonio con otras personas.

La segunda determinación presente en el texto constitucional fue la inclusión del derecho a voto verdaderamente universal al permitirse los derechos de sufragio femenino. Esto rompía la tradición (española, pero también de la generalidad de los países, más o menos en los mismos tiempos) de la omisión de referencia alguna expresa en los textos políticos de la época a la idea de igualdad política y de representatividad de los hombres y de las mujeres, lo que suponía un verdadero freno a la progresiva extensión del principio democrático típico de finales del siglo xix y de la primera mitad del siglo xx, pero siempre carente de la presencia femenina en el ejercicio del derecho a la participación política. Tras una, ya suficientemente estudiada en innumerables trabajos publicados, disputa por los constituyentes, especialmente por parte de las mujeres constituyentes (curiosamente, tras la llegada del nuevo régimen el nuevo gobierno provisional declaró elegibles a las mujeres por Decreto de 8 de mayo de 1931, tratándose de un hito histórico poco valorado), se aprobó el artículo 36, que reconoció «los mismos derechos electorales» para los ciudadanos de uno y otro sexo mayores de 23 años.

Por último, la Constitución, en su artículo 46, hizo otra referencia específica a las mujeres, esta vez en materia laboral, al disponer que la legislación social regularía «el trabajo de las mujeres y de los jóvenes, y especialmente la protección de la maternidad».

En definitiva, que la Segunda República apostó sin lugar a duda alguna por la no discriminación por razón de sexo en todos los ámbitos jurídicos, aunque las declaraciones constitucionales, en algún caso concreto como el de la situación jurídica de la mujer casada, no se vieron acompañadas de la necesaria y conveniente reforma de la legislación pertinente, en este caso el Código civil, que siguió manteniendo en su articulado las disposiciones relativas al papel predominante del marido y secundario de la esposa. Pudo deberse en todo caso a la difícil vida política del régimen republicano y a su final abrupto.

Terminado el sistema republicano, y establecido el régimen dictatorial, a cuyo frente se situó el general Franco, no cabe duda de que los avances en materia de derechos de la mujer sufrieron un violento frenazo y un posterior retroceso. Se puede afirmar que la peculiar declaración de derechos -y de deberes- de la dictadura franquista se estableció en una norma dictada unos años después de la guerra civil, y recién acabada la Segunda Guerra Mundial, tal vez por ser ese momento el de asentamiento (y tranquilidad) del régimen, visto el panorama en que había quedado Europa, y estando Espańa necesitada de un sistema de normas políticas que sustituyese la norma suprema habitual de todos los países del entorno europeo, una Constitución. No se optó por una Constitución, ni en el sentido formal ni en el sentido material, sino por un conjunto de leyes supremas del sistema político, que llegó a ser conocido como Leyes Fundamentales del Estado ${ }^{3}$. Esa norma, la llamada a ser

\footnotetext{
3 Serían, con el paso del tiempo y con pretensiones de estabilidad, las siguientes: Ley de principios fundamentales del Movimiento Nacional, Fuero de los Españoles, Fuero del Trabajo, Ley
} 
la declaración de derechos y deberes de los ciudadanos, es el Fuero de los Españoles, aprobado el 17 de julio de 1945 (se modificó por la Ley Orgánica del Estado de 10 de enero de 1967), que era una verdadera síntesis de muchos de los principios políticos del nuevo régimen, pero también una explicación de su idea de la sociedad que se quería instaurar en Espańa en esos momentos y de construcción de un modelo social definitivo. Y de ahí que, además de relacionar los deberes y derechos, se haga un diseño sociopolítico que encierra una fuerte carga ideológica extremadamente autoritaria, aunque el texto se salpique de proclamaciones de derechos que a la larga van a quedar como papel mojado, como las referencias a la libertad o a la igualdad.

Por esta razón vale la pena hacer algunas referencias a este texto, casi siempre olvidado en los estudios jurídicos sobre la época, y especialmente en los de los derechos de las mujeres, sin que deba olvidarse que estuvo vigente hasta el comienzo de la transición democrática de finales de los años setenta del siglo xx. La lectura del Fuero, que, como se dijo, pretendió ser un compendio de los derechos y de los deberes de los ciudadanos españoles, pero propio de un sistema férreamente autocrático, lleva rápidamente a la conclusión de que la propia denominación no implicaba, aunque lo pareciera, una exclusión de la mujer. La expresión «españoles» no se refiere solo a los hombres españoles, aunque el texto, además del título de la norma, hable continuamente de hombre, o de padres, pues se refiere a todos. Ahora bien, si se lee la norma en el contexto de la época, está claro que algunos de esos derechos, en la práctica, iban a ser ejercidos, por lo menos en los tiempos en que se dictó, únicamente por hombres; pero también los deberes, como el servir a la patria con las armas. Es decir, que da la sensación de que la norma no se planteó nada en este sentido, ni pretendió ser discriminatoria; era una declaración de derechos y deberes, y ya se vería quiénes ejercerían los unos y a quiénes obligarían los otros. En definitiva, que era una norma para todos, para el conjunto de la ciudadanía, pero estaba claro, por la configuración social de la época, que de aplicación preferentemente masculina, para lo bueno y para lo no tan bueno. Sería ilógico decir que no se refiere a las mujeres, puesto que, por ejemplo, regula el concepto de familia de la época, al tiempo que establece la obligación, a todos, de participar de la fe católica.

El Fuero de los Españoles comienza en su primer artículo con la proclamación general, que inspira todo el texto (o que debía hacerlo) del respeto a la dignidad, a la libertad y a la integridad del hombre como «titular de deberes y derechos», y continúa en el tercero declarando la «igualdad de derechos de todos los españoles, sin preferencia de clase ni acepción de personas", y aquí siempre debe suponerse que no hizo una referencia expresa a la discriminación por sexo porque se creía que no la había, ni el Fuero se había dictado solo para los hombres. Hay otros dos artículos que son especialmente relevantes a los efectos de este estudio, a falta de un precepto específico que hable de las mujeres, que como ya se puede deducir no se incluyó por considerarse innecesario, dado que se partía teóricamente de una ausencia de discriminación

constitutiva de las Cortes, Ley de Referéndum, Ley Orgánica del Estado y Ley de sucesión a la Jefatura del Estado. 
a este respecto (al margen de lo que fuera la realidad de la situación social y jurídica de la mujer). El artículo 22 regula la familia y el matrimonio, siendo un buen espejo de las ideas del régimen al respecto, incluidas las religiosas del catolicismo extremo. De una parte, en su primer párrafo, declara que el Estado reconoce y ampara a la familia como institución natural y fundamental de la sociedad, con derechos y deberes anteriores y superiores a toda ley humana positiva, mientras que en el segundo, con redacción categórica, regula el matrimonio, de una parte excluyendo cualquier forma de contraerlo que no sea la canónica, y de otra parte estableciendo la indisolubilidad del mismo, cuando señala que «el matrimonio será uno e indivisible». Por último, el artículo 23 se dedica a la descendencia familiar, estableciendo que «los padres están obligados a alimentar, educar e instruir a sus hijos». En definitiva, que este Fuero de los Españoles, dictado en los primeros años del régimen político franquista, ya ofrecía una perfecta delimitación de la situación de la mujer: no hay aparentemente discriminación alguna, el Fuero no lo hace, sino que coloca a cada persona en su lugar, al margen de que esto sea, sin duda alguna, una absoluta discriminación, que, como se verá, discurría por las sendas de lo fáctico y de lo jurídico.

\subsection{LOS DERECHOS DE LAS MUJERES EN LAS NORMAS JURÍDICAS DE LA ÉPOCA}

Las modificaciones jurídicas empezaron muy pronto: se dictan en plena guerra civil algunas disposiciones que eran un mero anuncio de una política bien trenzada de discriminación, y de lo que habría de venir. Se trata de la Ley de 5 de marzo de 1938, que ordenó la suspensión de los pleitos de divorcio (se derogó definitivamente la anterior Ley de divorcio de 1932 por nueva Ley de 23 de septiembre de 1939), y una semana más tarde, el día 12, la Ley que derogó la normativa anterior de matrimonio civil y concedió plena eficacia a los matrimonios contraídos en forma canónica, dado que aquel estaba «en pugna violenta con la conciencia nacional».

Dejando al margen estas normas referidas, el análisis del ordenamiento jurídico de las dos primeras décadas de régimen franquista lleva rápidamente a la conclusión de que lo que lo caracteriza desde este punto de vista es que ignora a la mujer y esta forma de ignorancia deriva de normas específicas o de normas generales que regulan de forma diferenciada a la mujer, y que no es producto precisamente de una conciencia de igualdad y de que no se regula nada porque nada hay que decir, sino que no se regula nada porque hay un statu quo de discriminación fáctica que no hace falta trasladarlo a la normativa. Esta circunstancia, por cierto, es la tónica de las grandes declaraciones de derechos de la historia contemporánea mundial hasta la primera mitad del siglo xx, que hablan en general pero que se interpreta que solo hablan de los hombres. Se quiere decir con esto que, en general, no hay normas que se refieran a la mujer (salvo las relativas a la mujer no emancipada o a la mujer casada en el Código civil), y todo ello al margen de que había una realidad social de absoluta diferenciación entre hombres y mujeres desde todos los puntos de vista, como se observa, a modo de ejemplo, en el papel de la mujer en la enseńanza, o en la religión, o como ama de casa, o su formación específica para su papel a cargo de la llamada Sección Femenina. 
La dictadura no suprimió el principal derecho político de una sociedad contemporánea, el derecho que otorga la posibilidad de participar en los órganos de gobierno de esa sociedad y de dirigirlos, el derecho de elegir a los representantes o ser elegido representante de la sociedad; en definitiva, el derecho de sufragio activo y pasivo. Fue un logro de la Segunda República el sufragio verdaderamente universal al incluirse en su Constitución el derecho al voto para hombres y mujeres. Pues bien, el régimen franquista no lo suprimió, no eliminó el derecho al voto de las mujeres; lo que hizo fue desnaturalizar hasta tal punto el derecho al sufragio, de todos, de hombres y mujeres, que hace que no se pueda hablar de idea de representatividad, de participación o de democracia. Es, por cierto, una obsesión de las dictaduras contemporáneas de los más variados signos buscar una especie de legitimación política mediante la convocatoria continua de procesos electorales o procesos de referéndum, con la idea de que sus ciudadanos puedan expresar su opinión, pero estos procesos alcanzan tal grado de intervencionismo del poder, y de manipulación de las voluntades de decisión, que esa pretensión de legitimidad resulta tan falseada como ridícula. A esta tendencia no escapó el régimen franquista, que sistemáticamente convocaba extrañas elecciones a las Cortes con una composición peculiar (únicamente a unos determinados procuradores en Cortes, elegidos por algunos sectores de la sociedad), alejada de cualquier parámetro democrático. La Ley Constitutiva de las Cortes 17 de julio de 1942, otra Ley Fundamental, no dispuso nada respecto del voto femenino, ni del masculino, aunque tenía un sistema electivo peculiar por sectores corporativos de la sociedad (familia, municipio y sindicato $)^{4}$, además de miembros natos y designados por el jefe del Estado, no prohibiendo en consecuencia el derecho de sufragio. Y ya la Ley de Referéndum de 22 de octubre de 1945, «por la que el jefe del Estado podrá someter a referéndum aquellas leyes que por su trascendencia lo aconseje o el interés público lo demande», como dice su propio nombre, dispuso en el artículo 2 que «el referéndum se llevará a cabo entre todos los hombres y mujeres de la Nación mayores de 21 ańos». Y, efectivamente, se celebraron algunos, y las mujeres pudieron votar, todos ellos con voto casi unánime a favor de las propuestas del régimen. Sirva de muestra que el 6 de julio de 1947 se celebró un referéndum para la aprobación popular de otra de las Leyes Fundamentales, en este caso la Ley de Sucesión a la Jefatura del Estado, y pudieron votar las mujeres, con los siguientes resultados oficiales, según los datos de la

${ }^{4}$ Posteriormente, la Ley Orgánica del Estado de 1967, aprobada precisamente en referéndum en el que votaron las mujeres (ya decía la Ley de Referéndum de 1945 que votan todos, hombres y mujeres), modificó la Ley Constitutiva de las Cortes de 1942 introduciendo un nuevo grupo de procuradores, en representación de las familias de España, junto a los que ya existían, y este cupo era elegido de forma popular con un peculiar cuerpo electoral. El artículo fue aprobado con el siguiente tenor literal: «f) dos representantes de la Familia por cada provincia, elegidos por quienes figuren en el censo electoral de cabezas de familia y mujeres casadas, en la forma que se establezca por ley». En definitiva, que en el referéndum votaban hombres y mujeres con el único requisito de la edad mínima, pero para elegir a sus procuradores en las Cortes solamente votaban hombres, en cuanto cabezas de familia, y mujeres casadas, en cuanto esposas de cabezas de familia. 
época: de un censo oficial de 16187992 electores, votaron 14454 426, de los que afirmativos fueron 12628983 , es decir, el 89,86 por ciento, mientras que los electores que votaron no fueron 643501 .

Al margen de esta aparente, pero muy engańosa, igualdad, al menos en el derecho al voto, lo cierto es que si se atiende al resto del ordenamiento se observa que las normas referidas a las mujeres no son numerosas, seguramente porque no hacía falta: la diferente situación jurídica de la mujer era un hecho, el producto de una realidad que se manifestaba en todos los órdenes de la vida, y, como ya se ha dicho, no hacía falta escribirlo en una norma.

Se trataría ahora de trazar un panorama de las normas que afectaban especialmente a la mujer, y la discriminaban, desde los distintos sectores del ordenamiento jurídico.

El Derecho penal de la época, cuyo texto regulador fundamental fue el Código penal de 1944, no pudo escapar de la visión genérica del régimen franquista de considerar a la mujer en una posición de inferioridad respecto del hombre y de la férrea moral correspondiente, lo que determina que lleve a cabo, por consiguiente, regulaciones específicas absolutamente atentatorias a la dignidad humana, la femenina en particular. Pero también ha de tenerse en cuenta que parte de esa normativa, como sucede, por ejemplo, con la regulación del uxoricidio y del adulterio, no fue invención de la época, sino más bien el rescate de una vieja tradición jurídica, pues son innumerables los textos de épocas anteriores que ofrecían tal regulación. La particularidad es el anacronismo que representaba al mantener vivas regulaciones similares a las que ya aparecían en los fueros medievales hispánicos en las Siete Partidas castellanas, tanto porque la Segunda República lo había eliminado como porque los tiempos y la sociedad habían cambiado, y lo que podía haber tenido cierta justificación en periodos remotos de la historia resultaba ahora de todo punto inadmisible al estar referido a una sociedad con cierto nivel de desarrollo desde cualquier punto de vista.

Por esta razón, la lectura, empezando con lo que hoy se puede llamar delitos sexuales, resulta sorprendente cuando, de una parte, parece que la víctima de la mayor parte de estos delitos (y especialmente del más grave, y más penado) solo puede ser la mujer, y, de otra parte, sorprende la lenidad de algunas penas, o mejor dicho la casi impunidad, como sucede con el adulterio cometido por el hombre, o con el uxoricidio u homicidio honoris causa.

Los artículos reguladores de la violación, el estupro y el rapto -el $429^{5}$, el $434^{6}$ y siguientes y el 440 y siguientes - solo admitían a la mujer como víctima en una especie de proteccionismo anómalo, mientras que el delito de abusos deshones-

\footnotetext{
de reclusión menor».

5 Art. 429 Código penal de 1944: «La violación de una mujer será castigada con la pena

${ }^{6}$ El art. 434 del Código penal de 1944 se refiere al estupro de una doncella mayor de doce años y menor de veintitrés, cometido por autoridad o cuidador.

7 Por ejemplo, el art. 440 del Código penal de 1994, que dispone que el rapto de una mujer ejecutado contra su voluntad y con miras deshonestas, será castigado con la pena de prisión mayor.
} 
tos en el art. $430^{8}$ se refiere a cualquier persona como víctima, al margen de su sexo. Al mismo tiempo, se introducía un mecanismo beneficioso para el condenado, pues para todos estos delitos (violación, abusos deshonestos, estupro y rapto) se preveía la posibilidad de la impunidad del autor o el no cumplimiento en el caso de condena, exigiéndose perdón y matrimonio, dado que el art. 443 señalaba que «el perdón expreso o presunto del ofendido, capaz legalmente, extingue la acción penal o la pena impuesta o en ejecución. El perdón no se presume sino por el matrimonio de la ofendida con el ofensor». E igualmente, un reflejo de la mentalidad de la época aparece con nitidez en el art. 444, al disponer que los reos de violación, estupro o rapto serán también condenados por vía de indemnización «a dotar a la ofendida, si fuere soltera o viuda», así como a «reconocer a la prole», y a «mantener a la prole».

La regulación del delito de adulterio también es significativa tanto por ser la continuidad, ahora parcialmente renovada, de una arraigada tradición histórico-jurídica, puesta nuevamente en vigor (en realidad, es una vuelta a una peculiar, y propia de tiempos pasados, especie de sistema de autotutela, aunque con pena irrisoria), como por la desigualdad de sexos ante una misma acción, que se calificaba como delictiva, pero que encubría una actitud despectiva ante la mujer. Basta la lectura del art. 428 a estos efectos: «El marido que, sorprendiendo en adulterio a su mujer, matare en el acto a los adúlteros o alguno de ellos, o les causare cualquiera de las lesiones graves, será castigado con la pena de destierro. Si les produjere lesiones de otra clase, quedará exento de pena. Estas reglas son aplicables, en análogas circunstancias, a los padres respecto de sus hijas menores de veintitrés años y sus corruptores, mientras aquellas vivieren en la casa paterna. El beneficio de este artículo no aprovecha a los que hubieren promovido, facilitado o consentido la prostitución de sus mujeres o hijas». En definitiva, que se podía imponer la pena de destierro como castigo a hechos tan notorios como un homicidio, o dos homicidios, o a las lesiones graves, o la exención de la responsabilidad criminal para las lesiones no graves.

Todo esto se acompañaba además con la regulación diferenciada del propio delito de adulterio en función del sexo de su autor, pues si lo cometía una mujer (casada), la previsión legal, que lo calificaba expresamente de adulterio, se encontraba en el art. 449, que lo castigaba con prisión menor (también para el que fuera condenado por tener las relaciones con ella) en una redacción peculiar, al decir que «el adulterio será castigado con la pena de prisión menor. Cometen adulterio la mujer casada que yace con varón que no es su marido, y el que yace con ella sabiendo que es casada, aunque después se declare nulo el matrimonio». Además, el Código añadía otra especie de autotutela cuando permitía que el marido engañado dispusiera a su criterio del cumplimiento efectivo de la pena por su esposa condenada, pues así lo señalaba el art. 451 al referir que el marido podrá en cualquier tiempo remitir la pena impuesta a su consorte (y la del adúltero). En cambio, el adulterio del marido no merecía tal nombre en el Código, si bien llevaba aparejada la misma

${ }^{8}$ Art. 430 del Código penal de 1944: «El que abusare deshonestamente de persona de uno u otro sexo [...] será castigada con la pena de prisión menor». 
pena, aunque a diferencia del de la esposa aquí se exigía cierta habitualidad y permanencia en la acción, de ahí que pareciera quedar impune la relación sexual esporádica; aparece en el art. 452, al decir que el marido que tuviere manceba dentro de la casa conyugal, o notoriamente fuera de ella, será castigado con prisión menor, mientras que introducía cierta dosis de benevolencia penológica en relación con la mujer, dado que la manceba sería castigada, a criterio judicial, con la misma pena de prisión menor o la de destierro.

En definitiva, y dejando de lado otros tipos penales significativos a estos efectos, como las estrictas y duramente penadas regulaciones del delito de aborto, o el uso de anticonceptivos, lo relevante es destacar que, desde el punto de vista jurídico-penal, la diferenciación por sexos existía, y que no era siempre con afán de protección, sino de auténtica discriminación con extrañas regulaciones en cuanto a sus posibles castigos que iban desde la exención de la responsabilidad criminal, la lenidad o la importancia del perdón.

Desde la perspectiva jurídico-laboral, el principal texto regulador de esta materia, el Fuero del Trabajo de 1938, también con la categoría de Ley Fundamental, y que es en verdad un compendio de la visión económica y social del nuevo régimen, ya hizo mención específica a la mujer, si bien mínima, pues se debió considerar que era irrelevante cualquier otra referencia en un mundo del trabajo que no estaba pensado para las mujeres. Así, en el art. 1 de la parte II se dice, cuando se habla de la defensa del trabajador, de su vida y de su trabajo, que el Estado «en especial, prohibirá el trabajo nocturno de las mujeres y niños, regulará el trabajo a domicilio y liberará a la mujer casada del taller y de la fábrica». A continuación, dictó el Decreto ley de 31 diciembre 1938 con ciertas medidas mitigadoras y, en concreto, prohibió el trabajo de la mujer casada a partir de determinados ingresos del marido. En el Reglamento Nacional del Trabajo de 27 de diciembre de 1939, se insistió en que la mujer debe cesar en su trabajo al casarse, y en las Regulaciones Laborales de 1942 se preceptuó que la mujer, al casarse, deja su puesto a cambio de la dote nupcial. Estas normas reflejaban la concepción ideológica del régimen, ya esbozadas en esta materia en el citado Fuero de Trabajo, y que eran la expresión de una realidad asentada sobre la idea de que el hombre trabaje para que sea el sostén económico de la familia, mientras que la vida de la mujer la conduce inevitablemente al matrimonio. Para terminar con estas citas legales, en la Ley de Contrato de Trabajo de 26 de enero de 1944 se prohibió a las mujeres el trabajo en determinadas tareas y se impuso un descanso mínimo de 12 horas entre jornadas.

Será la normativa civil la materia en que haya una regulación más densa y específica acerca de la mujer, reflejo de una concepción no solo meramente diferenciadora, sino discriminatoria. Son múltiples los preceptos del Código civil en este sentido, tanto en cuanto a la condición femenina en general como en cuanto a la situación jurídica de la mujer casada; se trata de los preceptos limitadores de su capacidad de obrar; de los actos que la mujer puede realizar con plena autonomía y de aquellos para los que es preceptiva la licencia marital. Además, de aquellos que contemplan el poder del marido en la casa familiar, en los actos de gestión y administración de sus intereses personales y económicos, entre otros. En general, esos artículos eran limitadores de derechos, al mismo tiempo que colocaban a la mujer 
en posición de inferioridad respecto del hombre, especialmente el marido, lo que se pone de manifiesto sobre todo con la licencia marital y la potestad doméstica de este.

Aunque la mayoría de edad estaba en los 23 años (art. 320 Código civil) a comienzos del régimen franquista, en virtud de lo dispuesto en la Ley de 13 de diciembre de 1943, a partir del 1 de enero de 1944 la mayoría de edad se adquiere a los 21 años. No obstante, las mujeres tenían otra importante limitación en el art. 321 (reformado por Ley de 20 de diciembre de 1952) ${ }^{9}$ al no poder abandonar el hogar familiar hasta los 25 años salvo que tuvieran licencia de sus padres, o para contraer matrimonio, o para entrar en una institución religiosa católica, o también cuando el padre o la madre hubieran contraído ulteriores nupcias o concurriera alguna otra causa que justificara la separación. Por otra parte, aparece otra limitación en el art. 22 del Código civil, que hasta la Ley de 22 julio de 1954, en que se modificó y desapareció, decía que «la mujer casada sigue la condición y nacionalidad de su marido», y que «la española que casare con extranjero podrá, disuelto el matrimonio, recobrar la nacionalidad espańola» con los requisitos del art. 21. La nueva Ley de 1954 en su redacción del art. 22 sí que estableció que «la mujer casada no podrá por sí sola adquirir voluntariamente otra nacionalidad, a menos que esté separada legalmente». A este debe añadirse la prohibición de ser testigos en los testamentos del art. 681.1 y la prohibición de ejercer cargos tutelares como ser tutores ni protutores que señala expresamente el art. 237.7, o ser vocales del consejo de familia (art. 294).

La situación jurídica de la mujer casada en la época, hasta las reformas parciales que llevó a cabo la Ley de 24 de abril de 1958, se podría analizar distinguiendo lo que podía hacer de lo que no podía hacer.

En cuanto a lo que podía realizar al menos formalmente, aparte de las facultades de disposición de los bienes parafernales y para los actos que se deriven del ejercicio de la potestad doméstica que le corresponda según el art. $62^{10}$, el art. 63 permite a la mujer casada otorgar testamento y ejercer los derechos y cumplir los deberes que le correspondan respecto a los hijos legítimos o naturales reconocidos que hubiera tenido con otro, y respecto a los bienes de los mismos. Según el segundo párrafo del art. 60, también puede defenderse en juicio criminal, y demandar y defenderse en los pleitos con su marido, o cuando hubiere obtenido habilitación conforme a lo que dispone la Ley de Enjuiciamiento Civil al respecto. Igualmente viene facultada por el art. 1413 para actuar cuando el marido disponga, administre o enajene

9 El artículo 321 originario del Código civil, vigente hasta la Ley de 20 de diciembre de 1952, decía los siguiente: «A pesar de lo dispuesto en el artículo anterior, las hijas de familia mayores de edad, pero menores de veinticinco ańos, no podrán dejar la casa paterna sin licencia del padre o de la madre en cuya compańía vivan, como no sea para tomar estado, o cuando el padre o la madre hayan contraído ulteriores bodas».

${ }^{10}$ Art. 62 del Código civil: «Son nulos los actos ejecutados por la mujer contra lo dispuesto en los anteriores artículos, salvo cuando se trate de cosas que por su naturaleza estén destinadas al consumo ordinario de la familia, en cuyo caso las compras hechas por la mujer serán válidas. Las compras de joyas, muebles y objetos preciosos, hechas sin licencia del marido, sólo se convalidarán cuando éste hubiese consentido a su mujer el uso y disfrute de tales objetos». 
los bienes conyugales de forma fraudulenta o contraria a la ley, causando perjuicio a la mujer ${ }^{11}$, y, por último, también puede exigir la constitución de hipoteca e inscripción de los bienes dotales, como dispone el art. 1352.

$Y$ en cuanto a lo que no estaba autorizada ni podía hacer se encuentra una variada gama de disposiciones limitadoras de la mujer casada en lo personal y en lo patrimonial. En lo personal destaca el deber de obediencia a su marido del art. $57^{12}$, o el deber de seguir a su marido donde quiera que fije su residencia, salvo, previa autorización judicial, "cuando el marido traslade su residencia a Ultramar o país extranjero", como dice el art. 58, o el ya citado deber de seguir la condición o nacionalidad de su marido del art. 22, derogado por la Ley de 22 de julio de 1954, o en la patria potestad la preferencia por el padre de su ejercicio sobre los hijos comunes del art. 154.1. Y en lo patrimonial, la potestad del marido domina igualmente sobre los bienes y el patrimonio de la mujer, y de ahí la prohibición de la administración de la sociedad conyugal del art. 59, por lo que le corresponde a este el derecho de administrar los bienes matrimoniales en el régimen económico de la sociedad de gananciales (art. 1412), y la dote (art. 1357), la instauración de la representación de la mujer por su marido y la prohibición de comparecer en juicio sin la licencia de este contemplada en el art. 60, o la prohibición del art. 61 de adquirir la mujer casada a título oneroso o lucrativo, enajenar sus bienes, ni obligarse sin licencia de su marido.

Esta fue la situación jurídica de la mujer tras la guerra civil, que, en realidad, era la misma desde la promulgación del Código civil en 1889 (con la salvedad de los ańos de tendencia igualadora de la Segunda República), reflejo de una concepción tanto de la superioridad del hombre como de una familia de dirección unitaria y jerarquizada por parte del marido. Sin embargo, durante la década de los cincuenta se empezó a considerar la conveniencia de adecuar la rígida normativa a la realidad socioeconómica y, sobre todo, a cierto cambio de mentalidades que veían absurdo el enorme campo discriminatorio de la mujer y la razonabilidad de introducir leves reformas de tendencia igualitaria. Así se hizo con las ya citadas Ley de 20 de diciembre de 1952 y Ley de 22 de julio de 1954, y se hará sobre todo con la Ley de 24 de abril de 1958, una de las grandes normas reformadoras de la época, dicho esto en el sentido del momento.

Esta Ley de 1958 pretendió la modificación de ciertos preceptos, tanto sobre la mujer en general como sobre la mujer casada en particular, pero con especial relevancia en cuanto a la ampliación de la capacidad de obrar -aunque en la norma se aluda, incorrectamente, a su capacidad jurídica- de la mujer y a la modificación del régimen económico de gananciales. "Aborda el problema de la capacidad jurídica de la mujer, que hace mucho tiempo se hallaba planteado [...]», «liberar a la mujer de ciertas limitaciones en su capacidad", así se manifiesta la propia Exposición de Motivos de la Ley. En síntesis, y en lo que aquí afecta, cabe destacar, en primer lugar, que se reformó el art. 237, sustituyendo la prohibición a la mujer en general

${ }^{11}$ La redacción originaria de este art. 1413 se modificó por la Ley de 24 de abril de 1958.

12 Art. 57 Código civil: «El marido debe proteger a la mujer, y ésta obedecer al marido». 
para ser tutora o protutora por la prohibición a la mujer casada sin licencia; se autorizó a la mujer para ser parte del consejo de familia; y, además, se eliminó la prohibición de ser testigo en los testamentos. En segundo lugar, se eliminó la diferencia de trato en el adulterio como causa de separación (que antes se establecía de forma claramente discriminatoria en el art. 105.1 y ahora pasa a contemplar el adulterio de cualquiera de los cónyuges); se estableció el mantenimiento de la patria potestad sobre sus hijos para la mujer que se casa de nuevo del art. 168. Y, en tercer lugar, la regulación del consentimiento de la mujer casada en la sociedad de gananciales para los actos dispositivos sobre bienes inmuebles o establecimientos mercantiles del art. 1413 del Código civil. En fin, como tímidos avances pueden ser calificadas estas reformas, siempre en el sentido de mejoras de la situación jurídica de la mujer.

Para terminar el estudio de este periodo, cabe mencionar, no tanto por su eficacia jurídica sino por ser un compendio de la ideología del régimen, una norma a la que se dio carácter también de Ley Fundamental del sistema franquista, tardía en el tiempo pero especialmente significativa por tratarse de un listado de los criterios que debían estar en la base del funcionamiento de la sociedad y el Estado. Esta Ley de Principios fundamentales del Movimiento Nacional de 1958 declaró que el Quinto Principio "funda la comunidad nacional en el hombre y en la familia», del que se puede predicar que es coherente con lo que ya llevaba insistiéndose en toda la normativa y en la concepción ideológica previa desde el final de la guerra civil, y sin que la utilización del término "hombre» se haga en un sentido exclusivamente masculino, al margen de la evidente superioridad masculina en lo fáctico del régimen. Igual coherencia puede observarse en el Sexto Principio, que sostiene que «las entidades naturales de la vida social (familia, municipio y sindicato) son las estructuras básicas de la comunidad nacional», y de ahí que fuera ese el modelo de la representación popular por tercios en las elecciones a Cortes. Sirva este texto para concluir que la situación jurídica de la mujer se estabilizó desde los primeros momentos del régimen, con las levísimas modificaciones, insuficientes e insustanciales de la citada Ley de 24 de abril de 1958 . Habrá que esperar a la posterior reforma del articulado del Código civil relativo a la mujer casada, operada por la relevante Ley 14/1975, de 2 de mayo, sobre reforma de determinados artículos del Código civil y del Código de comercio sobre la situación jurídica de la mujer casada y los derechos y deberes de los cónyuges, para que se pueda atisbar cierta cercanía de lo legal con lo social y con el ya inevitable fin de la discriminación, proceso que empezará su culminación con la Constitución de 1978.

\subsection{BREVE REFERENCIA A LA LEgISLACión SOBRE LA IGUALDAD JURÍdiCA DE LA MUJER EN LAS DOS ÚlTIMAS DÉCADAS DEL RÉGIMEN DE FraNCO}

Tras el paréntesis que para los derechos de la mujer supuso el franquismo, en las dos últimas décadas se produjo una tímida apertura en la que hay que destacar las siguientes leyes por la relativa importancia que tuvieron.

La primera es la Ley 56/1961, de 22 de Julio, sobre derechos politicos profesionales y de trabajo de la mujer, que, en su Preámbulo, después de decir que el prin- 
cipio de no discriminación por razón del sexo ni estado para ejercer los derechos políticos y profesionales y laborales ya está reconocido en el Fuero de los Españoles, añade que «la presente Ley no tiene por objeto otra finalidad que la de desarrollar y dar aplicación efectiva a tales principios, suprimiendo restricciones y discriminaciones basadas en situaciones sociológicas que pertenecen al pasado y que no se compaginan ni con la formación y capacidad de la mujer espańola ni con su promoción evidente a puestos y tareas de trabajo y de responsabilidad».

En el texto de esta Ley se afirma que el sexo por sí solo no puede implicar limitación y se establece la posibilidad de que pueda acceder a los distintos cuerpos y carreras de funcionarios de administraciones públicas y privadas. No obstante, esta posibilidad no es total, sino que, como el propio Preámbulo indica, esto es «sin otra cortapisa que la derivada de la existencia de trabajos que exigen esfuerzos desmesurados, respecto de los cuales, tanto la pura naturaleza como las convenciones internacionales sobre la materia suscritas por España, imponen la limitación». Y así, se puede observar que su articulado, tras reconocer que «la mujer puede participar en la elección y ser elegida para el desempeño de cualquier cargo público» y que "puede ser designada asimismo para el desempeño de cualquier cargo público del Estado, Administración Local y Organismos autónomos dependientes de uno y otra" (artículo segundo), o que "puede participar en oposiciones, concursos-oposiciones y cualesquiera otros sistemas para la provisión de plazas de cualesquiera Administraciones públicas. Asimismo, tendrá acceso a todos los grados de la enseñanza» (artículo tercero. Uno), a continuación, establece una serie de excepciones al estar vetado su ingreso en las armas y cuerpos de los Ejércitos de Tierra, Mar y Aire, salvo que por disposición especial expresa se conceda a la mujer el acceso a servicios especiales de los mismos; a la Administración de Justicia en los cargos de magistrados, jueces y fiscales, salvo en las jurisdicciones tutelar de menores y laboral; y tampoco puede ser personal titulado de la Marina Mercante, excepto las funciones sanitarias.

Como se puede comprobar, se trata de una muy tímida reforma, que, lejos de reconocer la igualdad total, mantiene una desigualdad para el ejercicio de determinadas profesiones.

Y si esto es así en lo referente al acceso a los diferentes cuerpos y carreras de funcionarios de Administraciones públicas, otro tanto se puede decir en lo referente a su capacidad para la contratación laboral, ya que si bien el artículo cuarto en su apartado uno establecía que «la mujer podrá celebrar toda clase de contratos de trabajo», y que «en las reglamentaciones de trabajo, convenios colectivos y reglamentos de empresa no se hará discriminación alguna en perjuicio del sexo", añadía un párrafo por el que se excluía a la mujer de determinados trabajos, al decir que «las disposiciones reglamentarias determinarán los trabajos que, por su carácter penoso, peligroso o insalubre, deben quedar exceptuados a la mujer».

Por otra parte, la preeminencia del hombre sobre la mujer queda patente en la necesidad que se establecía en la legislación de la autoridad marital para el ejercicio de los derechos recogidos en dicha Ley. Expresamente, el artículo quinto preveía que cuando se exigiera dicha autorización por la Ley, «deberá constar en forma expresa, y, si fuere denegada, la oposición o negativa del marido no será eficaz cuando 
se declare judicialmente que ha sido hecha de mala fe o con abuso de derecho». Es decir, si bien esta Ley supone un avance en los derechos de las mujeres, no deja de ser un avance muy limitado, pero al que no hay que privarle la importancia que tiene, dada la época en que fue dictada.

El 22 de julio de 1972 se dictó una nueva Ley ${ }^{13}$, que da una nueva redacción a los artículos 320 y 321 del Código civil, y fija la mayoría que edad a los veintiún ańos, otorgando, a partir de esta edad, capacidad para todos los actos de la vida civil, salvo las excepciones establecidas en casos especiales en el Código civil. De particular importancia es su artículo segundo, que deroga el número tercero del artículo 1880, y los artículos 1901 a 1919 de la Ley de Enjuiciamiento Civil. Se referían estos artículos a la posibilidad de decretar el depósito de la mujer soltera que «habiendo cumplido 20 ańos, trate de contraer matrimonio contra el consejo de sus padres y abuelos», y al procedimiento que se seguía para la constitución del depósito.

Por último, en el campo del derecho privado, la Ley 14/1975, de 2 de mayo de $1975^{14}$, reforma determinados artículos del Código civil y del Código de comercio sobre la situación jurídica de la mujer casada y los derechos y deberes de los cónyuges. Esta ley eliminó limitaciones a la capacidad de obrar de la mujer casada en las materias siguientes:

- En materia de nacionalidad, la mujer, hasta la aprobación de esta Ley, seguía la nacionalidad del marido. Tras esta reforma el matrimonio no dio lugar de manera automática a la adquisición, pérdida o recuperación de la nacionalidad española. Tanto la adquisición como la pérdida de la nacionalidad española tenían que ser voluntarias, y la recuperación, por la mujer casada, iba a seguir las reglas generales de toda recuperación de nacionalidad.

- En materia de capacidad de obrar de la mujer casada. Se suprimió la hasta entonces fórmula vigente por la que la protección era un atributo del marido, y la obediencia una obligación de la mujer. Esta discriminación dejó paso a un deber de protección mutuo y en interés de la familia, y a una participación igualitaria de la mujer en la determinación de la residencia de los cónyuges.

A partir de esta reforma, ninguno de los cónyuges ostentó la representación legal del otro, salvo que se confiriese voluntariamente. Se suprimió, por consiguiente, la necesidad de la licencia marital complementaria de la capacidad de la mujer para realizar actos o negocios jurídicos. Se respetó, eso sí, el régimen de consentimientos de ambos cónyuges que se necesitaba para determinados actos o negocios jurídicos.

${ }_{13}$ Ley 31/1972, de 22 de julio, Gaceta de Madrid núm. 36, 5 de febrero de 1881.

14 BOE núm. 107, de 5 de mayo de 1975. 
Durante la tramitación del procedimiento judicial de nulidad o separación del matrimonio, la mujer tuvo la administración de sus bienes. Y era el juez el que determinaba a quién correspondía la administración de los bienes gananciales.

Se eliminaron referencias a la no privación de la autoridad marital en los casos de prodigalidad, o a limitaciones especiales para la mujer menor en casos de tutela, que se encontraban recogidas en el Código civil. Asimismo, se suprimió la incapacidad que tenía la mujer casada para ser tutor o protutor, o la excusa para no serlo por el hecho de ser mujer.

En la cuestión relativa a la herencia, se eliminó la licencia marital para que pudiese ejercer el cargo de albacea la mujer casada, y para aceptar o repudiar las herencias; también se la facultó para pedir la partición de la herencia. Y en relación con el consentimiento en los contratos se suprimió la imposibilidad que tenía la mujer de prestar consentimiento, una imposibilidad que la colocaba en la misma situación que los locos o dementes y los sordomudos que no sepan escribir, o que los menores no emancipados.

En materia del régimen económico-matrimonial, se introdujo la posibilidad de modificarlo por voluntad de ambos cónyuges, a través de las capitulaciones matrimoniales.

Asimismo, en relación con los bienes privativos de la mujer o parafernales, la mujer, a partir de esta Ley, pudo disponer por sí sola de dichos bienes. Y una vez producida la separación judicial por sentencia firme, cualquiera de los cónyuges podía pedir la separación de bienes y ostentar la plena propiedad de aquellos que se le fueron adjudicados. En caso de que la separación se produjese por ausencia o interdicción, los bienes que se adjudicaran al ausente o interdicto los iba a administrar su representante o tutor. Por otra parte, la mujer administraba los bienes del matrimonio en caso de abandono de familia del marido. Además, cuando era la mujer la que administraba los bienes tenía idénticas facultades y responsabilidad que el marido cuando era este quien ejercía la administración.

Por último, el mismo criterio que utilizó la Ley para la reforma de la capacidad jurídica de la mujer casada en el Código civil se mantuvo para el Código de comercio, facilitando el ejercicio del comercio por ambos cónyuges y suprimiendo la antigua necesidad de la autorización marital.

\section{LA LEGISLACIÓN SOBRE LA IGUALDAD JURÍDICA DE LA MUJER TRAS LA MUERTE DE FRANCO}

\subsection{La Constitución española de 1978}

Tras la muerte de Franco, la regulación de los derechos de la mujer va a cambiar. El aislamiento internacional del régimen de Franco supuso un retroceso en comparación con lo que ocurría en otros países del entorno, en especial, en las democracias europeas occidentales. M. ${ }^{a}$ Carmen Sevilla González, en un reciente discurso de la apertura del curso 2019-2020 de la Universidad de La Laguna, afirma que si «el final de la contienda mundial significó en Occidente la conclusión de una 
etapa histórica significativa, es lo cierto que en España la situación política existente mantuvo la vigencia de unos criterios sociales, morales y políticos que resultaban obsoletos en el resto de Europa durante unas décadas más, hasta la llamada Transición democrática» ${ }^{15}$.

Fruto de la Transición democrática es la Constitución española, aprobada y promulgada el 27 de diciembre de 1978, que iba a cambiar el panorama de la igualdad de derechos de la mujer y ser el punto de arranque de las modificaciones legislativas que se iban a producir en los años posteriores. Dentro del articulado de la Constitución alguno expresamente se refiere a la igualdad jurídica de la mujer y el hombre. Es en estos artículos en los que se centra en esta sección, pero para una mejor comprensión de su texto es muy útil conocer alguna de las intervenciones parlamentarias, bien en su defensa, presentando enmiendas, o pidiendo su supresión. Es cierto que no nos podremos referir a todas estas intervenciones, y solo se recogerán aquellas que tienen más interés para el tema objeto de este estudio.

Publicado el Anteproyecto de Constitución el 5 de enero de $1978^{16}$, en su artículo 9, el apartado 1, establecía que los poderes públicos y los ciudadanos están sometidos a la Constitución y el ordenamiento jurídico "cuyos principios rectores son la libertad y la igualdad». Y su apartado 2 , decía que corresponde a los poderes públicos «promover las condiciones para que la libertad y la igualdad del individuo [...] sea real y efectiva [...]». El artículo 14 del Anteproyecto establecía la igualdad de todos los españoles ante la ley sin discriminación por razón del sexo. El artículo 23 apartado 2 incorporaba el derecho de todos los ciudadanos a acceder en condiciones de igualdad a las funciones y cargos públicos. El artículo 27, en su apartado 1, decía que «a partir de la edad núbil, el hombre y la mujer tienen derecho a contraer matrimonio y a crear y mantener, en igualdad de derechos, relaciones estables de familia». Y, por último, el artículo 30, apartado 2, en lo concerniente a la remuneración de los trabajadores, decía que en «ningún caso podrá hacerse discriminación por razón del sexo». Alguno de estos artículos, a medida que avanza la discusión, no solo varían en su contenido, sino también en su numeración.

Se inició el debate del Anteproyecto en la Comisión de Asuntos Constitucionales y Libertades Públicas del Congreso de los Diputados, que aprobó el artículo 9 , con 27 votos a favor y ninguna abstención ${ }^{17}$. Cuando se entró en la discusión del artículo 13 (que correspondía con el artículo 14 del Anteproyecto), la única diputada de la Comisión, María Teresa Revilla López, que formaba parte de la Unión de Centro Democrático (UCD), manifestó:

En este artículo que hemos votado afirmativamente, la mujer espańola adquiere, por fin la plenitud de derechos. Es verdad que la votación ha sido unánime, sin disidencias, como estaba reclamando nuestra sociedad. Pero las mujeres no vamos

15 Sevilla González, María Carmen, La igualdad juridica: un Proyecto inacabado (perspectiva desde la historia del derecho comparado), Universidad de La Laguna, septiembre 2019, p. 13.

16 Boletín Oficial de las Cortes, núm. 44 (en adelante BOC) 05/01/1978.

${ }^{17}$ Diario de Sesiones del Congreso (en adelante DSC), núm. 67, 16/05/1978, p. 2389. 
a dar las gracias por ello. Tampoco vamos a mirar hacia el pasado con amargura o con rencor. Ahora buscamos el futuro y en el futuro queremos simplemente poder ser, para ser lo que podamos. Queremos conservar nuestra feminidad, que es un atributo precioso de la humanidad y, al mismo tiempo, sin renunciar a poder ser protagonistas de nuestra propia vida y a participar en igualdad de esfuerzos y responsabilidades en el quehacer común.

Para ello necesitamos, además de la igualdad ante la ley, de una sociedad rica en posibilidades de vida y en formas de existencia, una sociedad flexible en sus sistemas de trabajo y educación, donde no sean incompatibles la maternidad y el trabajo, la vida familiar y la cultura. La mujer necesita de una sociedad flexible y plural, pero también la necesita el hombre, que empieza hoy a sentirse atrapado en un destino unidimensional.

Y para terminar, Señorías, que no se piense que la crisis de identidad de la mujer es solo un problema femenino, de mujeres, porque es un problema de la sociedad en su conjunto. La sociedad lo sufre y la soiedad se enriquecerá en sus soluciones ${ }^{18}$.

El texto del ahora artículo 14 fue aprobado por unanimidad.

El debate sobre el artículo 31, que correspondía al artículo 27 del Anteproyecto, da lugar a una importante discusión, pero esta se centra en el apartado 2, que era el que recogía en su texto el mandato para que el derecho civil regule las causas de separación y disolución del matrimonio. Fue el divorcio el caballo de batalla que llevó a algunos diputados del partido Alianza Popular, como Gregorio LópezBravo y de Castro y Licinio de la Fuente de la Fuente, a proponer su eliminación del texto constitucional y la no constitucionalización del divorcio ${ }^{19}$. Pero, en lo que a este estudio se refiere, el contenido del apartado 1 no dio lugar a debate alguno, y el texto completo del ahora artículo 31, con sus dos apartados, fue aprobado con solo dos votos en contra.

Al fin, tras publicarse el 1 de julio de 1978 el Dictamen de la Comisión de Asuntos Constitucionales y Libertades Públicas del Congreso ${ }^{20}$, fue presentado, el 5 de julio de 1978, al Congreso de los Diputados, el Dictamen del Proyecto de Ley de la Constitución española ${ }^{21}$. Estos artículos se integran en el Proyecto con los números 9, apartado 2; artículo 13; artículo 23; artículo 30, apartado 1; y artículo 32. Son de nuevo aprobados por amplia mayoría de votos, y de nuevo, como había ocurrido en las discusiones de la Comisión, el debate más amplio lo originó el apartado 2 del artículo 30, en lo referente a la constitucionalización del divorcio, que produjo de nuevo las enmiendas de López-Bravo y de Castro ${ }^{22}$, y del también diputado de Alianza Popular Pedro de Mendizabal Uriarte ${ }^{23}$.

${ }_{18}$ DSC, núm. 69, 18/05/1978, pp. 2445-2446.

19 DSC, núm. 72, 23/05/1978, en pp. 2614-2617, se puede leer la intervención de LópezBravo y De Castro y en pp. 2617-2620 la de De la Fuente de la Fuente.

${ }^{20}$ BOC, núm. 121, 01/07/1978.

${ }^{21}$ DSC, núm. 104, 05/07/1978.

22 DSC, núm. 107, 11/07/1978, pp. 4073-4077.

23 Ibidem, pp. 4077-4082. 
Enviado el Proyecto de Constitución al Senado, se inició el debate del Proyecto en la Comisión de Constitución el 18 de agosto de 1978. El texto del artículo 9 fue aprobado después de haber sido retiradas dos enmiendas que pretendían darle otro emplazamiento, o bien que figurase como artículo independiente.

Mayor discusión originó el artículo 13, que decía: «Los españoles son iguales ante la ley, sin discriminaciones por razón de nacimiento, de raza, de sexo, de religión, de opinión o por cualquier otras circunstancias personales o sociales». El senador Cela y Trulock presentó in voce una enmienda de carácter léxico, que finalmente fue aprobada, al entender que no se debe llamar circunstancias a las que son condiciones, como el sexo o la raza ${ }^{24}$. No fue aceptada, en cambio, la enmienda presentada por el senador Justino de Azcárate Florez, que pretendía reducir el texto del artículo al siguiente: «Los españoles son iguales ante la ley». Como le rebatió Luis Sánchez Agesta, la enumeración de las circunstancias y condiciones aparece en todas las declaraciones de derechos en general, porque van apareciendo aquellos derechos que son negados ${ }^{25}$. Uno de ellos lo había sido la igualdad por razón del sexo.

El apartado 1 del artículo 30, que decía: «A partir de la edad núbil, el hombre y la mujer tienen derecho a contraer matrimonio y a crear y mantener, en igualdad de derechos, relaciones estables de familia», sí que fue objeto de un amplio debate en la Comisión de Constitución del Senado. Además de la enmienda in voce del senador Cela y Trulock, que finalmente fue aprobada, consistente en sustituir la frase «a partir de la edad núbil», por «a partir de la edad fijada por la ley», existieron otras muchas que proponían modificar la redacción del texto del apartado $1^{26}$. De todas las intervenciones que se produjeron para defender sus enmiendas, se trae a estas páginas la de la senadora María Belén Landaburu Fernández, por el contenido de sus palabras. Manifiesta que había planteado una enmienda al apartado segundo del artículo 30, pero que después de haber escuchado el debate que había ocasionado el apartado primero, consideraba más adecuado plantearla en este

${ }^{24}$ Diario de Sesiones del Senado (en adelante DSS), Comisión de Constitución, núm. 43, 24/08/1978, p. 1799.

${ }^{25}$ Ibidem, p. 1800.

${ }^{26}$ DSS, Comisión de Constitución, núm. 45, 29/08/1978, así p. 2001, Xirinacs Damians, planteó una enmienda al apartado 1 del art. 30, que decía: «Toda persona tiene derechos al desarrollo de su afectividad y de su sexualidad, a contraer matrimonio, a crear relaciones estables de familia en libertad, en plena igualdad de derechos y deberes de los consortes entre sí y de ambos respecto a los hijos comunes y a decidir libremente el número de hijos que desea tener. A tal fin tiene derecho a acceder a la información necesaria y a los medios que permitan su ejercicio». El senador Villar Arregui, del Grupo Parlamentario de Progresistas y Socialistas Independientes (p. 2002), propone redactarlo así: «El matrimonio se origina en el consentimiento de los cónyuges y se funda en la igualdad de derechos y deberes recíprocos». El senador de UCD, Vicente Domínguez (pp. 2003-2004) propuso la siguiente redacción: «El hombre y la mujer, desde la edad que determine la legislación civil, tienen derecho a contraer matrimonio y crear, en igualdad de derechos, una familia». El también senador de UCD Antonio Fernández-Galiano Fernández (p. 2006), cree que o debe mencionarse la igualdad en el momento de contraer matrimonio, pues ya está en el artículo 13, pero sí debe hacerse «muy claramente cuando se trata de las relaciones entre los que ya son cónyuges, en el curso y en el acontecer de la vida matrimonial». 
con el objeto de que se recoja el principio de igualdad jurídica entre los cónyuges. La razón que esgrime es que la Comisión ha aprobado en el artículo 13 el principio de igualdad ante la ley sin discriminación, entre otras razones, por razón del sexo; que en el artículo 23 recoge el derecho a acceder en condiciones de igualdad a las funciones y cargos públicos. Es decir, se ha traducido constitucionalmente el principio de no discriminación en la esfera del Derecho público. Su pretensión -dicees "trasladar a la esfera del Derecho privado este principio de no discriminación, a la esfera del Derecho familiar, del Derecho matrimonial». Si no se hiciera así, se dejaría su regulación a una Ley Orgánica, «y podría ocurrir que no se hiciera con arreglo a este principio de igualdad jurídica, lo que supondría, de una parte, desconocer este principio que parece desprenderse el artículo 13 de la Constitución y, de otra, un evidente retroceso». Retroceso - dice- porque ya está reconocido en la Ley de 2 de mayo de 1975 por el que se modificaron diversos artículos del Código civil y del Código de comercio, y modificó las relaciones de los consortes dentro de la relación matrimonial, la nacionalidad de la mujer casada, los relativos a la fijación del domicilio conyugal, la supresión de la licencia marital, la capacidad de la mujer casada para el ejercicio del comercio, etc. La enmienda que defendió decía: "A partir de la edad núbil, el hombre y la mujer tienen derecho a contraer matrimonio basado en la igualdad jurídica entre los cónyuges ${ }^{27}$.

Una vez votadas las enmiendas, el texto definitivo del apartado 1 del artículo 30, que fue aprobado por la Comisión de Constitución del Senado, tenía la siguiente redacción: «El hombre y la mujer, a partir de la edad fijada por la ley, tienen derecho a contraer matrimonio basado en la igualdad jurídica de los cónyuges $\aleph^{28}$.

Aprobados también, tal como estaban redactados, el apartado 2 del artículo $23^{29}$ y el artículo $32^{30}$, la discusión del Proyecto de Constitución pasó al Pleno del Senado, que tuvo comienzo el 25 de septiembre de 1978.

Los artículos 9 y el antiguo artículo 13, que definitivamente pasa a ser el 14, fueron aprobados en la sesión del 26 de septiembre de $1978^{31}$. Mayor debate suscitó, en la sesión del 28 de septiembre de 1978, el artículo 32 -que corresponde al antiguo 30-, si bien centrado principalmente en el tema del divorcio. No obstante, no deja de haber alusiones a la igualdad jurídica del hombre y de la mujer, como la del senador Lluís Maria Xirinacs i Damians, pues, aunque la redacción del apartado 1 del artículo 32 le parecía claramente insuficiente, ya que «se consagra una vez más, como en otros textos constitucionales, la mentalidad clásica del matrimonio», reco-

27 Ibidem, Landaburu GonzÁlez, pp. 2004-2005.

${ }^{28}$ Ibidem, p. 2008.

${ }^{29}$ DSS, Comisión de Constitución, núm. 44, 25/08/1978.

30 DSS, Comisión de Constitución, núm. 45, 25/08/1978.

31 DSS, núm. 59, 26/09/1978, pp. 2951-2952, fue aprobado el apartado 2 del art. 9, por 137 votos a favor y 14 en contra, con 11 abstenciones; los apartados 1 y 3 por 152 votos a favor, ninguno en contra y 1 abstención. En p. 2962 consta que fue aprobado por 190 votos a favor y ninguno en contra, sin abstenciones. 
nocía que «hay la mejora, la corrección importante de la igualdad de los cónyuges ${ }^{32}$ ». El artículo 32 fue aprobado en dicha sesión ${ }^{33}$. Asimismo, en la misma sesión, después de rechazar otra enmienda presentada por el senador Xirinacs i Damians, rebatida por el senador de UCD Julio Nieves Borrego, fue aprobado el artículo $35^{34}$.

Tras las modificaciones propuestas por el Pleno del Senado, el 28 de octubre de 1978 fue publicado el Dictamen de la Comisión Mixta del Congreso y Senado sobre el Proyecto de Constitución, en el que los artículos 9 apartado 2, 14, 23 apartado 2, 32 apartado 1 y 35 apartado 1 tenían la redacción que finalmente fue aprobada por ambas Cámaras el 31 de octubre de 1978, y que formaran parte del texto definitivo de la Constitución española sancionada y publicada el 27 de diciembre de 1978. Esta redacción es la siguiente:

\section{Artículo 9.2}

Corresponde a los poderes públicos promover las condiciones para que la libertad y la igualdad del individuo y de los grupos en que se integra sean reales y efectivas; remover los obstáculos que impidan o dificulten su plenitud y facilitar la participación de todos los ciudadanos en la vida política, económica, cultural y social.

Artículo 14

Los espańoles son iguales ante la ley, sin que pueda prevalecer discriminación alguna por razón de nacimiento, raza, sexo, religión, opinión o cualquier otra condición o circunstancia personal o social.

Artículo 23.2

Asimismo, tienen derecho a acceder en condiciones de igualdad a las funciones y cargos públicos, con los requisitos que señalen las leyes.

Artículo 32.1

El hombre y la mujer tienen derecho a contraer matrimonio con plena igualdad jurídica.

32 DSS, núm. 61, 28/09/1978, p. 3049. Xirinacs Damians creía en un modelo de relaciones más amplio que el incluido en el texto del proyecto constitucional. Así, decía (p. 3050), refiriéndose a la enmienda que defendía: «Creo que el texto recuerda un poco los Estados Unidos a finales del siglo pasado con sus clásicas reivindicaciones feministas de primera hora. La enmienda recoge la vida que bulle al final del siglo presente de la forma más concisa posible. Aparte del matrimonio, reconoce que toda persona tiene derecho al desarrollo de su afectividad o de su sexualidad, a contraer matrimonio, a crear relaciones estables de familia en libertad, en plena igualdad de derechos y deberes de los consortes entre sí y de ambos con respecto de los hijos comunes y a decidir libremente el número de hijos que deseen tener. A tal fin tienen derecho a acceder a la información necesaria y a los medios que permitan su ejercicio». Su enmienda fue rechazada.

33 Ibidem, p. 3054, fue aprobado el artículo 32 por 160 votos a favor y 1 en contra, con 9 abstenciones.

34 Ibidem, p. 3059, fue aprobado el artículo 35 por 148 votos a favor, ninguno en contra y 3 abstenciones. 


\section{Artículo 35.1}

Todos los españoles tienen el deber de trabajar y el derecho al trabajo, a la libre elección de profesión u oficio, a la promoción a través del trabajo y a una remuneración suficiente para satisfacer sus necesidades y las de su familia, sin que en ningún caso pueda hacerse discriminación por razón de sexo.

\subsection{LA LEGISLACIÓN SOBRE LA IGUALDAD JURÍDICA DE LA MUJER EN LAS TRES ÚL- TIMAS DÉCADAS DEL SIGLO XX}

Tras la aprobación de la Constitución española de 1978, se sucedieron diferentes leyes en el terreno de la igualdad jurídica de las mujeres y del hombre que afectaron a diferentes campos del Derecho: al Derecho civil, al penal -en este campo incluso antes de ser aprobada la Constitución-, al laboral. A esta legislación nos referiremos ahora, antes de abordar las leyes transversales que fueron aprobadas a comienzos del siglo Xxi y que afectaron a todos los campos del Derecho.

Si se comienza con la década de los setenta, las primeras reformas tuvieron lugar en el campo del Derecho penal, muy sensible a los cambios políticos. De ahí que, incluso antes de aprobarse la Constitución, ya se produjeron en la normativa penal modificaciones para adaptar su legislación a la nueva situación política. Es preciso tener en cuenta que el Código penal que estaba vigente era del año 1944, en el que estaba penado el adulterio y el amancebamiento, que fue despenalizado por la Ley 22/1978, de 26 de mayo, sobre despenalización del adulterio y del amancebamiento ${ }^{35}$. En efecto, el artículo 449 del Código penal de 1944 decía: «El adulterio será castigado con la pena de prisión menor. Cometen adulterio la mujer casada que yace con varón que no sea su marido, y el que yace con ella, sabiendo que es casada, aunque después se declare nulo el matrimonio». Y el artículo 452: «El marido que tuviere manceba dentro de la casa conyugal, o notoriamente fuera de ella, será castigado con prisión menor. La manceba será castigada con la misma pena o con la de destierro...». Por lo demás, en los artículos 450 y 451 se exigía querella del marido agraviado contra "ambos culpables», que no podía entablar en caso de que lo hubiere consentido, y asimismo preveía el perdón y la remisión de la pena impuesta por parte del marido. La ley 22/1978, en su artículo 1, deroga los artículos 449 a 452 del Código penal y suprime el capítulo de dicho Código que llevaba como rúbrica la expresión "Adulterio». También son derogados los artículos del Código civil que tenían su causa en el adulterio, como la incapacidad de suceder, o ser una causa de desheredación.

Tampoco se puede pasar por alto la Ley 45/1978, de 7 de octubre ${ }^{36}$, que despenaliza la divulgación y propaganda de anticonceptivos, que en el Código penal de 1944 estaban penados en el párrafo primero y en los apartados 4 y 5 de su artículo

35 BOE núm. 128, de 30 de mayo de 1978.

36 BOE núm. 243, de 11 de octubre de 1978. 
416. Por otra parte, la Ley 46/1978, de 7 de octubre ${ }^{37}$, modifica los delitos de estupro y de rapto, y desaparecieron exigencias del antiguo Código penal, como, en el delito de estupro, la de que la víctima fuese "doncella» o tuviese "acreditada honestidad», o «ser mujer honesta». En tanto que en el de rapto se va a penalizar atentar contra la libertad sexual de la mujer, en lugar del hecho de actuar «con miras deshonestas", como se recogía en el Código penal de 1944.

En la década de los ochenta hubo mucha actividad legislativa que afectó a la situación jurídica de la mujer. Cronológicamente, la primera Ley fue, en el campo del Derecho laboral, el Estatuto de los Trabajadores. En efecto, el artículo 35.1 de la Constitución española prohibió la discriminación por razón del sexo, y con la aprobación de la Ley 4/1980, de 10 de marzo de 1980 ${ }^{38}$, del Estatuto de los Trabajadores, este mandato se vio reflejado en alguno de sus artículos. Concretamente en los siguientes: en el apartado 2 del artículo 4, que, entre otros extremos, decía: «En la relación de trabajo, los trabajadores tienen derecho: [...] c) A no ser discriminados para el empleo o una vez empleados, por razones de sexo...». En el artículo 17, bajo el epígrafe "No discriminación en las relaciones laborales», en su apartado 1, estableció que «se entenderán nulos y sin efectos los preceptos reglamentarios, las cláusulas de los convenios colectivos, los pactos individuales y las decisiones unilaterales del empresario que contengan discriminaciones desfavorables por razón de edad o cuando contengan discriminaciones favorables o adversas en el empleo, así como en materia de retribuciones, jornadas y demás condiciones de trabajo, por circunstancias de sexo...». Y en el artículo 28, bajo el epígrafe "Igualdad de remuneración por razón de sexo», al decir que "el empresario está obligado a pagar por la prestación de un trabajo igual el mismo salario, tanto por salario base como por los complementos salariales, sin discriminación alguna por razón de sexo». No obstante, como mantiene Lousada Arochena, presentaba defectos importantes, como el de hacer una declaración de igualdad solo salarial y no por trabajo de igual valor, o mantener vestigios paternalistas como la titularidad femenina del permiso de lactancia ${ }^{39}$.

También en el campo del Derecho civil se produjeron modificaciones legislativas de importancia en la década de los ochenta. La primera Ley que se dictó es la Ley 11/1981, de 13 de mayo, de modificación del Código civil en materia de filiación, patria potestad y régimen económico del matrimonio ${ }^{40}$. Era una Ley que protegía a los hijos, y proporcionaba al hijo matrimonial, no matrimonial y adoptivo el mismo tratamiento. Suprimió la terminología anterior de hijo legítimo, ilegitimo o legitimado, pasando a denominarse matrimonial o no matrimonial. A partir de esta Ley la verdad biológica para determinar la paternidad adquirió la máxima relevancia (arts. 127-130 tras la reforma), frente a la prohibición que existía en la anterior

\footnotetext{
37 Ibidem.

38 BOE núm. 64, de 14 de marzo de 1980.

39 Lousada Arochena, José Fernando, El derecho fundamental a la igualdad efectiva de hombres y mujeres, Valencia, 2014, p. 92.

40 Publicada en BOE núm. 119, de 19 de mayo de 1981.
} 
redacción del Código civil, lo que constituyó un avance para la defensa de los intereses de los hijos y madres. En orden a determinar la filiación, el reconocimiento tuvo lugar sin límites en relación con los hijos (antes solo cabía reconocer a los hijos naturales), aunque primando siempre interés del reconocido ${ }^{41}$. Por otra parte, la patria potestad, a partir de esta Ley, se ejercitará conjuntamente por ambos progenitores, o por uno de ellos con el consentimiento del otro. También modificó el régimen económico del matrimonio, que se iba a estipular en capitulaciones matrimoniales, y en su defecto, la gestión y disposición de los bienes gananciales iba a corresponder, conjuntamente, a los cónyuges.

A pesar de no ser una ley que específicamente se refirió a la igualdad jurídica de mujeres y hombres, por su importancia, hay que destacar la que fue cronológicamente segunda reforma sustancial del Código civil tras la vigencia de la Constitución española, la Ley 30/1981, de 7 de julio, por la que se modifica la regulación del matrimonio en el Código civil y se determina el procedimiento a seguir en las causas de nulidad, separación y divorcio ${ }^{42}$. Uno de los artículos de la Constitución que había producido en 1978 mayor debate parlamentario fue el apartado 2 del artículo 32, porque decían los parlamentarios que se oponían a que fuese integrado en la Constitución, que su redacción equivalía a constitucionalizar el divorcio. La importancia de esta Ley se puede ver en las palabras del que era entonces ministro de Justicia, Fernández Ordoñez, en la presentación del Proyecto de Ley, que, entre otras cosas, dijo:

España lleva muchos siglos, desde la Cédula de 1564 de Felipe II, con la realidad invariable de una tradición de indisolubilidad, que atraviesa, incluso, nuestro proceso constitucional desde la Constitución de Cádiz y recorre todo el siglo xIX hasta llegar a la primera, y hasta ahora única, formulación del divorcio vincular en el artículo 43 de la Constitución de 1931.

Como consecuencia de esta declaración de la Constitución de 1931 se promulgaron las leyes de 1932 de matrimonio civil y de divorcio. Poco más tarde, en plena guerra civil, el 12 de mayo de 1938 queda derogada esta legislación: se permitió la revocación de los divorcios dictados con arreglo a ella y se declararon nulos todos los matrimonios civiles contraídos durante la guerra.

Hoy, casi cincuenta años después, reiniciamos el esfuerzo de incorporar a nuestro derecho una figura jurídica con cerca de dos siglos de antigüedad, desde la revolución liberal ${ }^{43}$.

${ }^{41}$ Sobre el alcance de esta reforma en la filiación vid. Moreno-Chinchilla Jiménez, Laura, «La filiación no matrimonial antes y después de 1981», Universidad Pontificia de Comillas, Madrid, abril 2014.

42 Publicada en $B O E$ núm. 172, de 20 de julio de 1981.

43 DSC, núm. 150, 17/03/1981. Dictamen de la Comisión de Justicia, sobre el Proyecto de Ley que modifica la regulación del matrimonio en el Código civil y se determina el procedimiento en las causas de nulidad, separación, divorcio. Fernández Ordoñez, p. 9397. En el debate se presentaron numerosas enmiendas, alguna a la totalidad y por diferentes razones, en unas ocasiones pidieron la devolución del Proyecto de Ley al Gobierno, ya que el divorcio no se debía establecer en la legislación, vid. Díaz-Pines Muñoz, de UCD, pp. 9402-9408, o Piñar López, de Fuerza Nueva 
A partir de esta Ley el divorcio ha estado vigente en España -con modificaciones parciales- ininterrumpidamente, hasta la actualidad.

En materia de Derecho de familia continuó la adaptación de la legislación a las normas constitucionales con la Ley 13/1983, de 24 de octubre, que reformó el Código civil en materia de tutela ${ }^{44}$. Es preciso tener en cuenta que en la redacción del Código civil anterior a esta reforma -a pesar de las modificaciones realizadas por la Ley 14/1975, de 2 de mayo de 1975-, se daba preferencia al padre para ejercer el cargo de tutor, con expresiones tales como que la tutela corresponde «al padre y en su caso a la madre» (artículos 220 y 227 de la redacción anterior). Asimismo, tenían preferencia para formar el Consejo de Familia las personas «que el padre, o la madre, en su caso, hubiesen designado...». (art. 294 redacción anterior), estableciendo una preferencia para integrarlo del «varón a la mujer» (art. 295 redacción anterior). Con la Ley de 24 de octubre de 1983 desaparecieron dichas expresiones y desigualdades estableciendo la igualdad de las mujeres y los hombres en materia de tutela.

También tuvo importancia la Ley 21/1987, de 11 de noviembre, por la que se modificaron determinados artículos del Código civil y de la Ley de Enjuiciamiento Civil en materia de adopción ${ }^{45}$. No solo porque se intentó que prevaleciera el interés del adoptado, sino porque, en lo que a este estudio se refiere, se modificó el artículo 9 del Código civil sobre derecho internacional privado, eliminando, como dice en su preámbulo, «discriminaciones hirientes contra la mujer». En efecto, modificó los apartados 4 y 5 del artículo 9 del Código civil. El apartado 4 decía: «Las relaciones paterno-filiales se regirán por la ley nacional del padre y en defecto de éste, o si sólo hubiere sido reconocida o declarada la maternidad, por la de la madre». El apartado 5, en su párrafo segundo, «en la adopción por marido y mujer a falta de ley nacional común, se aplicará la del marido al tiempo de la adopción». Estas discriminaciones contra la mujer desaparecieron en la nueva redacción. No obstante, quedó sin modificar el apartado 2 del artículo 9, que establecía: «Las relaciones personales entre los cónyuges se regirán por su última ley nacional común durante el matrimonio y, en su defecto, por la ley nacional del marido al tiempo de la celebración», y el apartado 3, que remitía las relaciones patrimoniales entre los cónyuges, en caso de que no existiesen capitulaciones, a la ley que regía las relaciones personales. Por lo que la discriminación contra la mujer continuó perviviendo.

En década de los ochenta también se continuaron las reformas en el campo del Derecho penal. La Ley Orgánica 8/1983, de 25 de junio ${ }^{46}$, modificó la condena para los reos de violación, estupro o rapto, pues en el Código penal de 1944 la indemnización consistía en "dotar a la ofendida, si fuera soltera o viuda», y tras la

(pp. 9410-9415). En otras ocasiones por considerar insuficiente la regulación que contenía el Proyecto, vid. Pi-Suñer Cuberta, de Esquerra Republicana de Catalunya (pp. 9398-9402), o Bandrés Molet, de Euskadiko Esquerra (pp. 9409-9410).

${ }_{44}$ Publicada en $B O E$ núm. 256, de 26 de octubre de 1983.

45 Publicada en $B O E$ núm. 275, de 17 de noviembre de 1987.

46 BOE núm. 152, de 27 de junio de 1983. 
reforma, se sustituyó por la de «indemnizar a la persona ofendida». Además, en esta reforma, como decía su Exposición de Motivos, «de acuerdo con la igualdad de la posición de los cónyuges, legalmente reconocida ya fuera del derecho penal, se suscribe la supresión a la mención de la autoridad marital, presente en varios preceptos». Y dentro de las faltas contra las personas, los apartados 2 y 3 del artículo 583, referentes a los maltratos del marido y la mujer, quedaron refundidos en un único apartado que decía: «El que maltratare a su cónyuge o hijos menores de palabra o de obra aunque no les causare lesiones de las comprendidas en el párrafo anterior».

La Ley Orgánica 3/1989, de 21 de junio ${ }^{47}$, supuso una nueva modificación del Código Penal. Sustituyó la expresión delitos «contra la honestidad» por la de delitos "contra la libertad sexual», al ser este el auténtico bien jurídico atacado. Incluyó en los delitos de violación, además del vaginal, el rectal y bucal, pudiendo ser sujetos pasivos tanto las mujeres como los hombres. Por otra parte, como decía la Exposición de Motivos de esta Ley, se incorporó al Código penal «una nueva modalidad de abandono de familia, consistente en el impago de prestaciones económicas establecidas por convenio o resolución judicial, en los casos de procesos matrimoniales».

Se entra, por fin, en la década de los noventa, en la que continuó la actividad legislativa en los tres campos del Derecho. En el Derecho civil, la Ley 11/1990, de 15 de octubre, sobre reforma del Código civil, en aplicación del principio de no discriminación por razón de sexo ${ }^{48}$, como decía en su Preámbulo, «pretende eliminar las discriminaciones que por razón de sexo aún perduran en la legislación civil y perfeccionar el desarrollo normativo del principio constitucional de igualdad». Las modificaciones más importantes que introdujo esta Ley en materia de igualdad de los derechos de la mujer con las siguientes:

Dio una nueva redacción de los apartados 2, 3, 5 y 8 del artículo 9 del Código civil, para dejar zanjada, de una vez por todas, la desigualdad que continuaba existiendo en Derecho internacional privado.

En relación con la adquisición de la vecindad civil, eliminó el apartado 4 del artículo 14, que decía que "la mujer casada seguirá la condición del marido, y los hijos no emancipados, la de su padre, y, en defecto de éste, la de su madre».

En materia de sucesiones fue modificado un párrafo del artículo 1066 del Código civil, que en la redacción anterior establecía que «cuando el mismo título comprenda varias fincas adjudicadas a diversos coherederos, o una sola que se haya dividido entre dos o más, el título quedará en poder del mayor interesado en la finca o fincas, y se facilitarán a las otras copias fehacientes, a costa del caudal hereditario. Si el interés fuere igual, el título se entregará al varón, y, habiendo más de uno, al de mayor edad». El último párrafo se sustituyó por otro que decía: «Si el interés fuere igual, el título se entregará, a falta de acuerdo, a quien por suerte corresponda».

47 BOE núm. 148, de 22 de junio de 1989.

48 Publicada en $B O E$ núm. 250, de 18 de octubre de 1990. 
Dentro del consentimiento de los contratos, se modificó el tercer párrafo del artículo 1267 del Código civil, que decía: «Para calificar la intimidación debe atenderse a la edad, al sexo y a la condición de la persona». Y fue sustituido por otro con la siguiente redacción: «Para calificar la intimidación debe atenderse a la edad y a la condición de la persona».

Por lo demás, la disposición transitoria de esta Ley estableció que «la mujer casada que hubiere perdido su vecindad por seguir la condición del marido, podrá recuperarla declarándolo así ante el Registro Civil en el plazo de un año a partir de la publicación de esta Ley».

En el Derecho laboral, se produjeron una serie de reformas que tuvieron lugar a partir del año 1994. La primera de ellas tuvo lugar con la aprobación de la Ley de 11/1994 de mayo de 1994, que modificó determinados artículos del Estatuto de los Trabajadores ${ }^{49}$. En concreto, el artículo 28 quedó redactado de la siguiente manera: «El empresario está obligado a pagar por la prestación de un trabajo de igual valor el mismo salario, tanto por salario base como por los complementos salariales, sin discriminación alguna por razón de sexo». Del mismo año es la Ley 42/1994, de 30 de diciembre ${ }^{50}$, en la que, como decía en su Preámbulo, «se configura como contingencia específica, desligada de la incapacidad laboral transitoria, la de maternidad $\aleph^{51}$.

Una nueva modificación del Estatuto de los Trabajadores tuvo lugar con la Ley 4/1995, de 23 de marzo, de regulación del permiso parental y por maternidad $^{52}$. Así, en la Exposición de Motivos de esta Ley, se decía que uno de los ámbitos en que la discriminación del género se seguía produciendo era el correspondiente al del acceso al mercado laboral en la selección de personal. Una de estas situaciones que condicionaban esta situación era la derivaba de «la posible baja o circunstancia tipificadas actualmente como incapacidad laboral transitoria del permiso por maternidad, así como la posibilidad de que se solicite la excedencia durante un período no superior a tres ańos para poder atender al cuidado de cada hijo indistintamente por parte del padre o bien de la madre». Para mitigar este problema, extendió el periodo de excedencia forzosa a todo el periodo de excedencia establecido por la Ley para el cuidado de los hijos, y como contrapartida los puestos que quedaban vacantes eran cubiertos por nuevos contratos en las condiciones que se establecía dicha ley ${ }^{53}$.

Otros aspectos que afectaban al trabajo de las mujeres también fueron objeto de una regulación a partir de esta década de los años noventa. Así la Ley 31/1995,

49 BOE núm. 122, de 23 de mayo de 1994.

50 BOE núm. 313, de 31 de diciembre de 1994.

51 Introduce en el Título II de la Ley General de la Seguridad Social un nuevo Capítulo IV bis que lleva por rúbrica «Maternidad» y que abarca los artículos 133, bis, 133, ter, 133 quater y 133 quinquies.

52 BOE núm. 71, de 24 de marzo de 1995.

53 Con tal finalidad esta Ley modificó el apartado 3 del artículo 46 del Estatuto de los Trabajadores. 
de 8 de noviembre, de Prevención de Riesgos Laborales, en su artículo 26, estableció que, en caso de que las condiciones de trabajo supusiesen un riesgo para la seguridad o la salud de las trabajadoras en situación de embarazo o parto reciente, el empresario estaba obligado a adoptar las medidas necesarias para evitar la exposición a dicho riesgo, a través de una adaptación de las condiciones o del tiempo de trabajo; y cuando esta adaptación no fuese posible, la trabajadora debía desempeñar un puesto de trabajo o función diferente y compatible con su estado. Y la Ley 39/1999, de 5 de noviembre, para promover la conciliación de la vida familiar y laboral de las personas trabajadoras ${ }^{54}$, creó la prestación de riesgo durante el embarazo, con la finalidad de proteger la salud de la mujer trabajadora embarazada ${ }^{55}$.

No se puede terminar este recorrido por la década de los noventa sin hablar de una Ley, la Ley Orgánica 5/1995, de 22 de mayo, del Tribunal del Jurado ${ }^{56}$, que, aunque es procesal, supuso la reintroducción del jurado en España, y, a diferencia de lo que ocurrió el anterior periodo en que estuvo vigente, supuso la participación de la mujer en el jurado en igualdad de condiciones que el hombre. Es cierto que la Ley republicana que modificó la Ley del Jurado entonces vigente dio paso, por primera vez en la historia de España, a que la mujer formase parte del jurado, y supuso un avance respecto a la legislación anterior, pero insuficiente, puesto que era muy limitada, ya que solo tenía lugar en los llamados crímenes pasionales, es decir, en los delitos de parricidio, asesinato, homicidio o lesiones, en los que el móvil pasional fuera el amor, los celos, la fidelidad o cualquier otro aspecto de las relaciones sexuales, y en los que fuesen de distinto sexo agresores y víctimas. Suspendido el jurado por un Decreto de la Junta de Defensa Nacional de 8 de septiembre de 1936, no volvió a establecerse en España hasta esta Ley de 22 de mayo de 1995, de ahí la importancia que tiene no solo por el restablecimiento del jurado, sino también para la igualdad jurídica de la mujer.

\section{LA LEGISLACIÓN SOBRE LA IGUALDAD JURÍDICA DE LA MUJER DEL SIGLO XXI}

\subsection{LAS LEYES TRANSVERSALES DE LA PRIMERA DÉCADA DEL SIGLO XXI}

Nos referiremos por último a dos leyes que se pueden calificar de transversales. Con esta denominación se hace referencia, como dice Lousada Arochena, a las leyes que sitúan el acento en la revisión de todo el ordenamiento jurídico, y «al afectar a todo el ordenamiento jurídico, son leyes que, rompiendo la técnica jurídica tradicional de ordenación atendiendo a la materia, contemplan las más diversas

${ }^{54} B O E$ núm. 266, de 06/11/1999.

55 Vid. Nuñez Fiaño, María del Carmen, El mutualismo judicial: acción protectora de la MUGEJU, Capitulo V. Acción protectora. Tesis doctoral inédita, defendida en octubre de 2019 en la Facultad de Derecho de la Universidad de A Coruña.

56 BOE núm. 122, de 23 de mayo de 1995. 
materias hasta potencialmente todas las abordables por el ordenamiento jurídico ${ }^{57}$. Las leyes a las que nos referimos en esta parte son la Ley Orgánica 1/2004, de 28 de diciembre, de Medidas de Protección Integral contra la Violencia de Género, y la Ley Orgánica 3/2007, de 22 de marzo, para la igualdad efectiva de mujeres y hombres.

a) Ley Orgánica 1/2004, de 28 de diciembre, de Medidas de Protección Integral contra la Violencia de Género.

El 7 de octubre de 2004, en el Congreso de los Diputados, el entonces ministro de Trabajo y Asuntos Sociales, Caldera Sánchez-Capitán, presentó y defendió el dictamen del Proyecto de Ley de Violencia de Género, con el objetivo básico de erradicar la violencia que se proyectaba hacia las mujeres. Para ello, como manifestó en su presentación del proyecto de ley, «articula nuevos organismos: Delegación del Gobierno contra la Violencia sobre la Mujer, Observatorio Nacional de Violencia sobre la Mujer». Y establecía medidas de protección integral en diversos campos: «En el ámbito de la publicidad y de los medios de comunicación», en el de «la educación incidiendo, en la primera etapa educativa y también en la enseñanza de adultos», en «la sensibilización y formación del personal sanitario para mejorar la atención y rehabilitación de la víctima», en «la especialización y coordinación de las Fuerzas y Cuerpos de Seguridad del Estado, policías locales, administraciones públicas», en «el reconocimiento de derechos laborales y de Seguridad Social», en "la sanción y persecución del agresor», y en "la especialización de juzgados» ${ }^{58}$. De la intervención de los diputados de los distintos grupos políticos en el debate sobre el Proyecto de Ley, pese a las enmiendas presentadas en aspectos tales como el de atribuir mayores competencias a las comunidades autónomas -principalmente defendidas por los grupos nacionalistas-, o que se extendiera la educación a la universitaria, o, en fin, un mayor alcance de la asistencia social y mayor dotación presupuestaria, y a pesar de la crítica general de la excesiva rapidez en la elaboración del Proyecto de Ley, se puede sacar la conclusión de que hay una coincidencia en la necesidad de esta Ley, y en definitiva, en dar un voto favorable a ella ${ }^{59}$. Tras el trámite parlamentario del Senado, el Proyecto de Ley fue remitido de nuevo al Congreso de los Diputados, y en la sesión del 22 de diciembre de 2004, después de una nueva intervención de los diputados de los distintos grupos parlamentarios, en las que mostraron su satisfacción de que muchas de sus enmiendas fueran incorporadas al texto del Proyecto de

57 Lousada Arochena, J. Fernando, op. cit., pp. 78-79.

58 Caldera Sánchez-Capitán, DSC, núm. 39, 7/10/2004, pp. 1703-1705.

59 Las enmiendas se pueden consultar en el DSC, núm. 39, 7/10/2004, pp. 1705-1720, en el que se pueden ver las intervenciones de los diputados Barkos Berruezo (Nafarroa Bai), Lasagabaster Olazabal (Eusko Alkartasuna), Fernández Dávila (Bloque Nacionalista Galego), Rodríguez Rodríguez (Coalición Canaria), García SuÁrez (Izquierda Verde-Izquierda Unida-Iniciativa per Catalunya Verds), Uría Etxebarría Grupo Parlamentario Vasco (EAJ-PNV), Bonàs Pahisa (Esquerra Republicana), Pigem i Palmés (Grupo Catalán de Convergència i Unió), Camarero Benítez (Grupo Parlamentario Popular). 
Ley en el Congreso y el Senado, fue votado y aprobado por unanimidad con 325 votos de todos los diputados concurrentes ${ }^{60}$.

La definitiva Ley Orgánica 1/2004, de 28 de diciembre, de Medidas de Protección Integral contra la Violencia de Género ${ }^{61}$, con alguna diferencia en la denominación de los nuevos organismos, que pasaron a ser denominados Delegación Especial del Gobierno contra la Violencia sobre la Mujer y Observatorio Estatal de Violencia sobre la Mujer, y la incorporación de alguna de las enmiendas presentadas, tales como la ampliación de la educación en igualdad de género a las universidades, dar mayores competencias a las comunidades autónomas o la ampliación de la asistencia social y medidas de protección a las víctimas, establece, en su articulado, en líneas generales los principios y las medidas de protección integral que había defendido el ministro de Trabajo y Asuntos Sociales en la presentación del dictamen del Proyecto de Ley.

La otra Ley transversal a la que nos referimos es la Ley Orgánica 3/2007, de 22 de marzo, para la igualdad efectiva de mujeres y hombres ${ }^{62}$. Fue presentado el Dictamen de la Comisión legislativa del Proyecto de Ley el 21 de diciembre de 2006 en el Congreso de los Diputados. Su presentación fue también llevada a cabo por el entonces ministro de Trabajo y Asuntos Sociales, Caldera Sánchez-Capitán, que la calificó como una ley transversal e integral, ya que «la ley expande el derecho a la igualdad entre mujeres y hombres en todo orden vital y se adentra en todos los ámbitos, sean públicos o privados». Y señaló los principales objetivos de la Ley, de los que destacó estos: lograr que las mujeres puedan acceder a los órganos de dirección de las empresas en las mismas condiciones que los hombres; prestar especial protección a las mujeres inmigrantes; lograr la igualdad en el mundo de la cultura, en el acceso a las nuevas tecnologías y a la sociedad de la información; extender la protección de la ley a las trabajadoras autónomas; flexibilizar el acceso a la prestación de maternidad; mejorar la conciliación de la vida personal, familiar y laboral; elevar la duración del permiso de paternidad; lograr una composición equilibrada de las listas electorales ${ }^{63}$. Los distintos grupos políticos, si bien en sus intervenciones formularon algunas enmiendas puntuales, mostraron un consenso a las líneas generales de la Ley, con la excepción del Grupo Parlamentario del Partido Popular, que, a través de su diputada Camarero Benítez, manifestó su voto en contra del Proyecto, tanto por imponer los planes de igualdad, defendiendo en su lugar una política de incentivos, como por el sistema de cuotas electorales que trata de imponer, además de añadir otros motivos, por ejemplo, entendía la diputada del Partido Popular que se debía ampliar el permiso de paternidad ${ }^{64}$.

${ }^{60}$ En DSC, núm. 61, 22/12/2004, pp. 2928-2942 se pueden leer las intervenciones y la votación final.

${ }^{61} B O E$ núm. 313, de 29/12/2004.

${ }^{62}$ BOE núm. 71, de 23/03/2007.

63 Caldera Sánchez-Capitán, DSC, núm. 225, 21/12/2006, pp. 11457-11459.

${ }^{64}$ Así, tanto Barkos Berruez (Nafarroa Bai), Fernández Dávila (Bloque Nacionalista Galego), Mardones Sevilla (Coalición Canaria), García Suárez (Izquierda Unida-Iniciativa per 
Remitida la Ley al Senado, se debatió el Dictamen de la Comisión de Trabajo y Asuntos Sociales, el 7 de marzo de 2007. La defensa volvió a llevarse a cabo por Caldera Sánchez-Capitán, que de nuevo insistió en lo que había expuesto en el Congreso de los Diputados. En la discusión del Senado no dejó de haber alusiones a la oportunidad de la fecha, ya que el día siguiente, el 8 de marzo, era el Día Internacional de la Mujer. La tónica general fue la misma que en la otra Cámara. Así, los senadores de los grupos de izquierdas y nacionalistas, si bien defienden algunas enmiendas, entre otras, encaminadas a dotar de planes de igualdad a empresas de menos de 250 trabajadores, o a que la composición de las listas electorales fuese de 50-50 - caso de Izquierda Unida-, o bien a dar mayores competencias a los gobiernos autónomos, o a extender la protección a la mujer en el mundo rural -caso de grupos nacionalistas-, pero todos mostraron su disposición a dar su voto favorable al Proyecto de Ley. En tanto que las senadoras Fúnez de Gregorio y Campo Piñeiro, del Grupo Parlamentario del Partido Popular, mostraron su disconformidad con el Proyecto e insistieron en las enmiendas que habían presentado en el Congreso, llegando a interesar que se añadiesen nuevas prestaciones como, entre otras, por riesgo durante la lactancia, movilidad, creación de bonos para guarderías, incentivos para la paridad en las listas electorales, eliminación de lenguaje sexista. Enmiendas que llevaron a senadoras de otros grupos, como a Aleixandre Cerarol, de Convergència i Unió, a considerarlas irrefutables si no fuera por el coste económico, o a la senadora del Grupo Parlamentario del Partido Socialista Martínez García a calificarlas como un «más y más que pondría en peligro la Seguridad Social» ${ }^{65}$.

El Proyecto de Ley enmendado fue aprobado en el Senado y se convirtió en la Ley Orgánica 3/2007, de 22 de marzo, para la igualdad efectiva de mujeres y hombres, compuesta de un título preliminar, 8 títulos integrados por 78 artículos, 31 disposiciones adicionales, 11 disposiciones transitorias, una disposición derogatoria y 8 disposiciones finales. Tras una Exposición de Motivos en la que se afirma que la igualdad efectiva de mujeres y hombres es un principio jurídico universal, reconocido en las distintas convenciones internacionales (Naciones Unidas 1979, Nairobi 1985, Beijing 1995) y que incorpora las últimas Directivas de la Comunidad Europea sobre igualdad (2002/73/CE, 76/207/CEE, 2004/113/CEE), incluyó en una Ley Orgánica los principios, políticas, acciones, planes y derechos que fueron sacados a la luz en el debate parlamentario, encaminados a la igualdad efectiva de mujeres y hombres.

No se puede pasar por alto que, a finales de la primera década del siglo XXI, se promulgó la Ley Orgánica 2/2010, de 3 de marzo, de salud sexual y reproduc-

Catalunya Verds), Uría Etxebarría (EAJ-PNV), Oliva i Peña (Esquerra Republicana), Pigem i PALmÉs (Convergència i Unió), ibidem, pp. 11459-11469, formularon entre otras enmiendas referentes a las competencias de sus territorios, en materia de conciliación, acogimiento, o el caso de niños prematuros, pero mostraron su disposición a su voto a favor. La discordancia se produjo por la diputada del Grupo Parlamentario del Partido Popular señora Camarero Díaz pp. 1169-11472.

65 Todas estas intervenciones se pueden ver en el DSS, núm. 113, 07/03/2007, pp. 68966922. 
tiva y de la interrupción voluntaria del embarazo ${ }^{66}$. El Preámbulo de esta Ley dice que «la protección de este ámbito de autonomía personal tiene una singular significación para las mujeres, para quienes el embarazo y la maternidad son hechos que afectan profundamente a sus vidas en todos los sentidos». Añade que diversos textos internacionales han puesto de manifiesto la relación de la protección de los derechos de la mujer con la protección sexual y reproductiva, mencionado en particular, en el ámbito de la Naciones Unidas, el artículo 12 de la Resolución 34/180, de 18 de diciembre de 1979, que establece que los Estados Partes deberán adoptar las medidas adecuadas para eliminar la discriminación de la mujer con el hombre en el acceso a los servicios de atención médica, incluida la planificación familiar. Otro de los textos a los que alude es el reconocimiento que se hizo en la Plataforma de Acción de Beijing acordada en la IV Conferencia de Naciones Unidas sobre la mujer, celebrada en 1995, del derecho de las mujeres a tener el control y decidir libre y responsablemente sobre su sexualidad, incluida la salud sexual y reproductiva, libre de presiones, discriminación y violencia. Y, por último, menciona la Resolución 2001/2128 (INI) del Parlamento Europeo sobre salud sexual y reproductiva y los derechos asociados, en la que se constatan las enormes desigualdades entre las mujeres europeas en el acceso a los servicios de salud reproductiva, a la anticoncepción y a la interrupción voluntaria del embarazo en función de sus ingresos, niveles de renta o el país donde residen.

El articulado de la Ley va incorporando dichas declaraciones y medidas. Es de destacar que conforme al artículo 14 de la Ley, en un plazo de catorce semanas las mujeres tienen la posibilidad de tomar una decisión libre e informada sobre la interrupción del embarazo.

Excepcionalmente, el artículo 15 a) y b) permite interrumpir el embarazo por causas médicas siempre que no se superen las veintidós semanas de gestación, cuando «exista grave riesgo para la vida o la salud de la embarazada y así conste en un dictamen emitido con anterioridad a la intervención por un médico o médica especialista distinto del que la practique o dirija». O bien «siempre que exista riesgo de graves anomalías en el feto y así conste en un dictamen emitido con anterioridad a la intervención por dos médicos especialistas distintos del que la practique o dirija».

A partir de la veintidós semana siguiente a la gestación, se considera que el nasciturus ya tiene vida independiente. Desde esa fecha, en caso de existir riesgo para la salud de la mujer, entiende la Ley que lo adecuado es un parto inducido. Si bien establece el artículo 15 c) dos supuestos excepcionales de interrupción del embarazo cuando «se detecten anomalías fetales incompatibles con la vida», o "se detecte en el feto una enfermedad extremadamente grave e incurable en el momento del diagnóstico y así lo confirme un comité clínico».

No se puede terminar este epígrafe sin hacer una referencia a un Anteproyecto que ha iniciado su trámite parlamentario, el de Ley Orgánica de garantía inte-

${ }^{66} B O E$ núm. 55, de 04/03/2010. 
gral de libertad sexual, al que dio luz verde el 3 de marzo de 2020 el Consejo de Ministros, y que supone una reforma de los delitos sexuales del Código penal, no solo en lo que se refiere a las penas, sino también en el consentimiento de las víctimas, provocada por los últimos casos de delitos de esta naturaleza en los que se ha cuestionado el consentimiento de la víctima al no haber una negativa expresa a la agresión sexual, de ahí que sea conocida como la Ley del «sí es sí». No obstante, en el momento de escribir estas líneas, aún es un Anteproyecto de Ley.

\subsection{BREVE REFERENCIA A LA LEGISLACIÓN AUTONÓMICA SOBRE LA IGUALDAD DE LA MUJER}

No quedarían completas estas reflexiones sin hacer una mención, aunque sea breve, a la labor llevada a cabo por los legisladores autonómicos en las reformas de los distintos Estatutos de Autonomía, para llevar a cabo la igualdad jurídica de la mujer. Estas reformas van incorporando en su normativa artículos similares para garantizar la igualdad de mujeres y hombres, proteger a las mujeres de la violencia de género, al tiempo que atribuyen a las Comunidades Autónomas la competencia exclusiva en políticas de igualdad. En muchas de estas Comunidades Autónomas ya se encontraban vigentes leyes de igualdad de género y de protección contra la violencia de género cuando se aprobaron estas reformas; en otras, fueron aprobadas con posterioridad. Sin ánimo de ser exhaustivo pues la reforma que hace cada Estatuto de Autonomía en esta materia requiere un estudio independiente, nos vamos a referir muy brevemente a ellas.

En la Comunidad Valenciana ya se había promulgado una Ley para la Igualdad entre mujeres y hombres, el 2 de abril de 2003, cuando se llevó a cabo la reforma de su Estatuto de Autonomía ${ }^{67}$. El Estatuto de Autonomía de Valencia fue reformado en el año $2006^{68}$, y en su artículo 11 establece que «la Generalitat, conforme a la Carta de Derechos Sociales, velará en todo caso para que las mujeres y los hombres puedan participar plenamente en la vida laboral, social, familiar y política sin discriminaciones de ningún tipo y garantizará que lo hagan en igualdad de condiciones. A estos efectos se garantizará la compatibilidad de la vida familiar y laboral». Y otorga competencia exclusiva a la Generalitat, en su artículo 49.1.26a, para la "promoción de la mujer».

En Cataluña, con anterioridad a la reforma de su Estatuto, una Ley del 9 de abril de 2001 modificó el apartado 2 del artículo 63 de la Ley 13/89, de 14 de diciembre, para exigir que las propuestas de disposición de carácter general de la

${ }^{67}$ Ley 9/2003, de 2 de abril, para la igualdad entre mujeres y hombres. BOE núm. 110, de 8 de mayo de 2003 .

${ }^{68}$ Ley Orgánica 1/2006, de 10 de abril, de Reforma de la Ley Orgánica 5/1982, de 1 de julio, de Estatuto de Autonomía de la Comunidad Valenciana. BOE núm. 86, de 11 de abril de 2006. 
Administración de la Generalitat de Catalunya vayan acompañadas de una memoria que, entre otros aspectos, ha de valorar la perspectiva de la igualdad de género.

El Estatuto de Autonomía de Cataluña tras su reforma ${ }^{69}$, dentro del capítulo I, sobre los derechos y deberes del ámbito civil y social, dedica el artículo 19 a los derechos de las mujeres, y establece:

1. Todas las mujeres tienen derecho al libre desarrollo de su personalidad y capacidad personal, y a vivir con dignidad, seguridad y autonomía, libres de explotación, malos tratos y todo tipo de discriminación.

2. Las mujeres tienen derecho a participar en condiciones de igualdad de oportunidades con los hombres en todos los ámbitos públicos y privado.

Pero no se quedan ahí sus previsiones, pues en el artículo 41, bajo el enunciado Perspectiva de género, establece la obligación de los poderes públicos de garantizar «el cumplimiento del principio de igualdad de oportunidades entre mujeres y hombres en el acceso a la ocupación, la formación, la promoción profesional, las condiciones de trabajo, incluida la retribución, y en todas las demás situaciones», «que las mujeres no sean discriminadas por causa de embarazo o maternidad», «la transversalidad en la incorporación de la perspectiva de género y de las mujeres en todas las políticas públicas para conseguir la igualdad real y efectiva y la paridad entre mujeres y hombres", "que se haga frente de modo integral a todas las formas de violencia contra las mujeres y a los actos de carácter sexista y discriminatorio; deben fomentar el reconocimiento del papel de las mujeres en los ámbitos cultural, histórico, social y económico, y deben promover la participación de los grupos y las asociaciones de mujeres en la elaboración y evaluación de dichas políticas». Así como su deber de «reconocer y tener en cuenta el valor económico del trabajo de cuidado y atención en el ámbito doméstico y familiar en la fijación de sus políticas económicas y sociales» y de "velar para que la libre decisión de la mujer sea determinante en todos los casos que puedan afectar a su dignidad, integridad y bienestar físico y mental, en particular en lo que concierne al propio cuerpo y a su salud reproductiva y sexual».

Para terminar, otorga a la Generalitat, en el artículo 153, la competencia exclusiva en materia de políticas de género.

Como en la Comunidad Valenciana, en la Comunidad Autónoma de las Illes Balears, ya estaba vigente una Ley de Igualdad de derechos entre hombre y mujeres, la Ley de 26 de septiembre de $2006^{70}$, antes de la aprobación de su reforma estatutaria. Por su parte, el Estatuto de Autonomía de las Illes Balears ${ }^{71}$, en su art. 16.3, dentro del Título II, referido a los derechos, los deberes y las libertades de los

${ }^{69}$ Ley Orgánica 6/2006, de 19 de julio, de reforma del Estatuto de Autonomía de Cataluña. $B O E$ núm. 172 , de 20/07/2006.

${ }^{70}$ Ley 12/2006, de 20 de septiembre, para la mujer. BOE núm. 248, de 17 d octubre de 2006.

${ }^{71}$ Ley Orgánica 1/2007, de 28 de febrero, de reforma del Estatuto de Autonomía de las Illes Balears. BOE núm. 52, de 01/03/2007. 
ciudadanos de las Islas Baleares, entre los ámbitos en que deberá centrarse primordialmente la actuación de las Administraciones públicas de las Islas Baleares, se encuentra «la igualdad de derechos de hombres y mujeres en todos los ámbitos, en particular en materia de empleo y trabajo; la protección social contra la violencia, especialmente la violencia de género». Y el artículo 17, bajo el epígrafe de No discriminación por razón de sexo, establece, en sus dos primeros números:

1. Todas las mujeres y hombres tienen derecho al libre desarrollo de su personalidad y capacidad personal, y a vivir con dignidad, seguridad y autonomía.

2. Las Administraciones públicas, según la Carta de Derechos Sociales, velarán en todo caso para que las mujeres y los hombres puedan participar plenamente en la vida laboral, social, familiar y política sin discriminaciones de ningún tipo y garantizarán que lo hagan en igualdad de condiciones. A estos efectos se garantizará la conciliación de la vida familiar y laboral.

Otorgando a la Comunidad Autónoma, de la misma manera que los dos Estatutos anteriores, la competencia exclusiva en "políticas de género» (art. 30.17).

En el año 2007 se reforma el Estatuto de Autonomía de Andalucía ${ }^{72}$, y su artículo 14, dentro del Título dedicado a los Derechos sociales, deberes y políticas públicas, prohíbe "toda discriminación en el ejercicio de los derechos, el cumplimiento de los deberes y la prestación de los servicios contemplados en este Título, particularmente la ejercida por razón de sexo». Garantiza, en su artículo 15, la igualdad de oportunidades entre hombres y mujeres. Y establece, en su artículo 16, el derecho de las mujeres a una protección integral contra la violencia de género, que incluya medidas preventivas asistenciales y ayudas públicas.

Son principios rectores del Estatuto de Autonomía de Andalucía «la lucha contra el sexismo» (art. 37.2. ${ }^{\circ}$ ), y la "plena equiparación laboral entre hombres y mujeres» (art. 37. 11. ${ }^{\circ}$ ). Además, se atribuye la Comunidad Autónoma la competencia exclusiva en materias de política de género, que incluye, conforme dispone el artículo 73:

a) La promoción de la igualdad de hombres y mujeres en todos los ámbitos sociales, laborales, económicos o representativos.

Se atribuye expresamente a la Comunidad Autónoma la facultad de dictar normativas propias o de desarrollo en esta materia.

b) La planificación y ejecución de normas y planes en materia de políticas para la mujer, así como el establecimiento de acciones positivas para erradicar la discriminación por razón de sexo.

c) La promoción del asociacionismo de mujeres.

${ }^{72}$ Ley Orgánica 2/2007, de 19 de marzo, de reforma del Estatuto de Autonomía para Andalucía. $B O E$ núm.68, de 20 de marzo de 2007. 
En el procedimiento de elaboración de sus normas (leyes y disposiciones reglamentarias) «se tendrá en cuenta el impacto por razón de género del contenido de la mismas» (art. 114). Y establece que, en el nombramiento de los titulares de los órganos de gobierno de la Administración andaluza, una ley regulará el principio de presencia equilibrada de hombres y mujeres (art. 135).

En fechas posteriores a la aprobación de esta reforma, fueron aprobadas en Andalucía leyes de igualdad de género y de protección contra la violencia de género, ambas de fecha 26 de noviembre de $2007^{73}$.

En Aragón, la reforma de su Estatuto de Autonomía ${ }^{74}$, tras prescribir en el artículo 12 todo tipo de discriminación, recoge el derecho de acceder en condiciones de igualdad a la cultura, desarrollo de las capacidades creativas y disfrute del patrimonio cultural, a los servicios públicos de salud, a participar en los asuntos públicos y a unos servicios públicos de calidad (artículos 13 al 15).

Uno de los objetivos a los que deben orientar sus políticas los poderes públicos aragoneses es, conforme al artículo $24 \mathrm{c}$ ), «a garantizar la igualdad entre el hombre y la mujer en todos los ámbitos, con atención especial a la educación, el acceso al empleo y las condiciones de trabajo».

Al igual que en otras reformas de los Estatutos de Autonomía, son competencia exclusiva de la Comunidad Autónoma de Aragón las "políticas de igualdad social, que comprenden el establecimiento de medidas de discriminación positiva, prevención y protección social ante todo tipo de violencia, y, especialmente la de género» (art. 71.37. $\left.{ }^{\mathrm{a}}\right)$.

Poco antes de la realización de esta reforma, en Aragón ya había sido aprobada una Ley de violencia de género, la de 22 de marzo de $2007^{75}$, con el objeto de adoptar medidas integrales para la sensibilización, prevención y erradicación de la violencia ejercida sobre las mujeres.

Asimismo, la reforma del Estatuto de Autonomía de Castilla y León de $2007^{76}$, en su artículo 14, prohíbe cualquier discriminación por razón de género, garantizando la transversalidad del principio de igualdad de género en todas sus políticas, "promoviendo acciones positivas para lograr la igualdad de oportunidades entre mujeres y hombres, sobre todo en los ámbitos educativo, económico, laboral, en la vida pública, en el medio rural, en relación con la salud y con los colectivos de mujeres en situación de necesidad especial, particularmente las víctimas de violencia de género».

${ }^{73}$ Ley 12/2007, de 26 de noviembre, para la promoción de la igualdad de género en Andalucía. BOE núm., 38, de 13 de febrero de 2008. Ley 13/2007, de 26 de noviembre, de medidas de prevención y protección integral contra la violencia de género. $B O E$ núm., 38, de 13 de febrero de 2008.

74 Ley Orgánica 5/2017, de 20 de abril, de reforma del Estatuto de Autonomía de Aragón. $B O E$ núm. 97, de 23 de abril de 2007.

75 Ley 4/2007, de 22 de marzo, de Prevención y Protección integral de las Mujeres Víctimas de Violencia de Aragón. BOE núm. 141, de 13 de junio de 2007.

${ }^{76}$ Ley Orgánica 14/2007, de 30 de noviembre, de reforma del Estatuto de Autonomía de Castilla y León. BOE núm. 288, de 1 de diciembre de 2007. 
Se atribuye la Comunidad de Castilla y León la competencia exclusiva en la "promoción de la igualdad de trato y de oportunidades entre hombres y mujeres, con particular atención a las mujeres víctimas de la violencia de género» (art. 70.1.11.º.

También en esta Comunidad Autónoma, cuando fue aprobada la reforma de su Estatuto de Autonomía, estaba vigente una Ley, de 3 de marzo de $2003^{77}$, de igualdad de mujeres y hombres. Con posterioridad, en el ańo 2010, se aprobó una Ley contra la violencia de género ${ }^{78}$.

La reforma del Estatuto de Autonomía de Canarias del año 2018 ${ }^{79}$, en el artículo 11, recoge el derecho a la no discriminación por razón del sexo, y el artículo 17 establece que los poderes públicos "garantizarán la igualdad efectiva entre mujeres y hombres en el ámbito público y privado, y velarán por la conciliación de la vida familiar y profesional». El mismo artículo prescribe "la adopción de medidas efectivas para educar en valores de igualdad no sexistas» y la realización de "políticas activas que proporcionen a las mujeres la protección integral a las víctimas de violencia machista, prestando especial atención a las medidas preventivas».

El acceso en condiciones de igualdad a la educación (art. 21.2), al ámbito laboral (art. 23), a la cultura (art. 27), a los servicios sociales (art. 29) también recogido en esta reforma. En la que es un principio rector de la política del Gobierno «la igualdad entre hombres y mujeres en todos los ámbitos, en particular, en materia de empleo, trabajo y retribución» (art. 37.4).

Con anterioridad a esta reforma, la Comunidad de Canarias ya había aprobado una Ley de prevención y protección integral de las mujeres contra la violencia de género, la Ley de 8 de abril de $2003^{80}$. Ańos después, el 26 de febrero de $2010^{81}$, aprobó una Ley de igualdad entre hombres y mujeres.

En la Región de Murcia, en su Estatuto de Autonomía, tras la modificación realizada en el artículo 10 por una Ley de 1998, en su número Uno, apartado 20, se atribuye la competencia exclusiva a la Comunidad Autónoma en materia de "promoción de la mujer» ${ }^{82}$. Con posterioridad, una Ley de 4 de abril de 2007, de igualdad entre mujeres y hombres ${ }^{83}$, tiene como objetivo introducir el principio de

77 Ley $1 / 2003$, de 3 de marzo, de Igualdad de oportunidades entre mujeres y hombres en Castilla y León. BOE núm. 71, de 24 de marzo de 2003.

${ }^{78}$ Ley 13/2010, de 9 de diciembre, contra la violencia de género en Castilla y León. BOE núm. 317, de 30 de diciembre de 2010.

${ }^{79}$ Ley Orgánica 1/2018, de 5 de noviembre, de reforma del Estatuto de Autonomía de Canarias. BOE núm. 268, de 6 de noviembre de 2018.

${ }^{80}$ Ley 16/2003, de 8 de abril, de Prevención y Protección Integral de las Mujeres contra la Violencia de Género. BOE núm. 162, de 8 de julio de 2003.

${ }^{81}$ Ley $1 / 2010$, de 26 de febrero, canaria de igualdad entre mujeres y hombres. $B O E$ núm. 45, de 5 de marzo de 2010.

${ }^{82}$ Ley Orgánica 4/1982, de 9 de junio, de Estatuto de Autonomía para la Región de Murcia. $B O E$ núm. 146, de 19 de junio de 1982. El artículo 10 se modifica por la Ley Orgánica 1/1998, de 15 de junio. $B O E$ núm. 143, de 16 de junio de 1998.

${ }^{83}$ Ley $7 / 2007$, de 4 de abril, para la Igualdad entre Mujeres y Hombres, y de Protección contra la Violencia de Género en la Región de Murcia. BOE núm. 176, de 22 de julio de 2008. 
transversalidad y, en consecuencia, aplicar la perspectiva de género en las distintas fases de la planificación y ejecución de todas las políticas públicas.

El Estatuto de Autonomía de Castilla-La Mancha, en su artículo Cuarto. Tres, establece que la Junta de Comunidades «propiciará la efectiva igualdad del hombre y de la mujer, promoviendo la plena incorporación de ésta a la vida social y superando cualquier discriminación laboral, cultural, económica o política» ${ }^{84}$. En tanto que una Ley de 18 de diciembre de $2010^{85}$ establece el derecho de igualdad y no discriminación por razón del sexo, y contiene medidas activas para implementar la igualdad, medidas contra la discriminación por razón del sexo, e introduce procedimientos con tal finalidad, al tiempo que refuerza las instituciones de promoción de la igualdad.

En la Comunidad Autónoma de Extremadura, una reforma de su Estatuto realizada en $2011^{86}$ dice, en su artículo 7 n. ${ }^{\circ} 12$, que es un «objetivo irrenunciable que informará todas las políticas regionales y prácticas institucionales, la plena y efectiva igualdad de la mujer en todos los ámbitos de la vida pública, familiar, social, laboral, económica y cultural». Y promueve una política activa para remover los obstáculos que impidan o dificulten la igualdad real y efectiva. Siendo, como otros Estatutos, competencia exclusiva de la Comunidad Autónoma, las políticas de igualdad de género (art. 9.29). Pocos meses después de la aprobación del Estatuto, se aprueba la Ley de 23 de marzo de 2011, de Igualdad entre mujeres y hombres y contra la violencia de género ${ }^{87}$.

En otras Comunidades Autónomas, aunque no se recoge expresamente en sus Estatutos de Autonomía la igualdad entre mujeres y hombres, o la protección contra la violencia de género, existen otras leyes específicas sobre la materia. Es el caso de Navarra, donde las Leyes Forales 22/2002, de 2 de julio, y la Ley Foral $12 / 2003^{88}$, que modifica la anterior, adoptan medidas para la sensibilización, prevención y erradicación de la violencia sexista.

En la Comunidad cántabra, la Ley de Cantabria 1/2004, de 1 de abril ${ }^{89}$, tiene como objeto la adopción de medidas integrales para la sensibilización, prevención y erradicación de la violencia de género, protección, atención y asistencia a las víctimas, hijos, hijas, o personas sujetas a su tutela o acogimiento.

${ }^{84}$ Ley Orgánica 9/1982, de 10 de agosto, de Estatuto de Autonomía de Castilla-La Mancha. BOE núm. 195, de 16 de agosto de 1982 .

${ }^{85}$ Ley 12/2010, de 18 de noviembre, de igualdad entre mujeres y hombres de Castilla-La Mancha. BOE núm. 37, de 12 de febrero de 2011.

${ }^{86}$ Ley Orgánica 1/2011, de 28 de enero, de reforma del Estatuto de Autonomía de la Comunidad Autónoma de Extremadura. BOE núm. 25, de 29 de enero de 2011.

${ }^{87}$ Ley 8/2011, de 23 de marzo, de Igualdad entre mujeres y hombres y contra la violencia de género en Extremadura. BOE núm. 88, de 13 de abril de 2011.

${ }^{88}$ Ley Foral 12/2003, de 7 de marzo, de modificación de la Ley Foral 22/2002, de 2 de julio, para la adopción de medidas integrales contra la violencia sexista. $B O E$ núm. 99 , de 25 de abril de 2003.

${ }^{89}$ Ley $1 / 2004$, de 1 abril, Integral para la Prevención de la Violencia Contra las Mujeres y la Protección a sus Víctimas. BOE núm. 101, de 26 de abril de 2004. 
Galicia cuenta, desde el 16 de julio de 2004, con una Ley para la igualdad de mujeres y hombres ${ }^{90}$, y desde el 27 de julio de 2007, con otra para la prevención y tratamiento integral de la violencia de género ${ }^{91}$.

En Euskadi, con el objeto de establecer los principios generales que han de presidir los poderes públicos en materia de igualdad de mujeres y hombres, y establecer una serie de medidas dirigidas a promover y garantizar la igualdad de oportunidades y trato en todos los ámbitos de la vida, promover la autonomía y fortalecer la posición social, económica y política de las mujeres, se aprobó la Ley para la Igualdad de Mujeres y Hombres de 18 de febrero de $2005^{92}$.

De similar manera, la Comunidad de Madrid, con la finalidad de prevenir la violencia de género, lograr una protección integral de las víctimas y combatir todos los aspectos, causas y manifestaciones de este fenómeno, aprobó la Ley de 20 de diciembre de $2005^{93}$.

En Asturias, el 11 de marzo de 2011, se aprobó una Ley para la Igualdad de mujeres y hombres y la erradicación de la violencia de género ${ }^{94}$, para promover la igualdad a través de políticas públicas y adoptar medidas activas para la sensibilización, prevención y erradicación de la violencia de género.

Este recorrido, aunque superficial, da una clara idea del compromiso del legislador autonómico, de igual forma que el estatal, en promover la igualdad de mujeres y hombres y erradicar la violencia de género. Un compromiso y avance legislativo que no deja de contrastar con los numerosos casos de violencia de género que se están produciendo en España, y de los que se hacen eco constantemente los medios informativos.

\section{REFLEXIONES SOCIOPOLÍTICAS ACERCA DE LA LEGISLACIÓN SOBRE LA IGUALDAD JURÍDICA DE LA MUJER EN ESPAÑA}

\subsection{Resumen Del CONTEXTo GLOBAL}

Un análisis profundo de la legislación sobre la igualdad jurídica de la mujer en España no estaría completo sin su adecuada contextualización dentro del movimiento occidental más amplio hacia los derechos de las mujeres que comenzó en

${ }^{90}$ Ley $7 / 2004$, de 16 de julio, gallega para la igualdad de mujeres y hombres. BOE núm. 228, de 21 de septiembre de 2004.

${ }^{91}$ Ley $11 / 2007$, de 27 de julio gallega para la prevención y el tratamiento integral de la violencia de género. $B O E$ núm. 226, de 20 de septiembre de 2007.

${ }_{92}$ Ley 4/2005, de 18 de febrero, para la Igualdad de Mujeres y Hombres. BOPV núm. 42, de 2 de marzo de 2005.

${ }^{93}$ Ley $5 / 2005$, de 20 de diciembre, integral contra la violencia de género de la Comunidad de Madrid. BOE núm. 52, de 2 de marzo de 2006.

${ }_{94}$ Ley $2 / 2011$, de 11 de marzo, para la igualdad de mujeres y hombres y la erradicación de la violencia de género. BOE núm. 106, de 4 de mayo de 2011. 
las últimas décadas del siglo xix. Aunque los vestigios monárquicos permanecen hasta la actualidad en muchos países, la gobernación republicana, en sus varias formas, se popularizaba tanto que se instituía casi universalmente en el mundo occidental durante los siglos XIX y xx. A medida que abundaba el republicanismo, rápidamente se hizo evidente que la igualdad era un elemento necesario para la gobernación democrática. Los países que intentaban mantener antiguas castas de desigualdad, tanto cultural como legislativa, se deterioraban en confusión política y social. Reconociendo la igualdad en la naturaleza inherente de la democracia misma, las leyes de sufragio femenino fueron codificadas en muchos países occidentales a principios del siglo xx. Tanto el movimiento hacia el republicanismo como los sucesivos movimientos por los derechos de las mujeres fueron interrumpidos por, y luego acelerados debido a, las dos guerras mundiales. Sin embargo, en el caso de España, los avances logrados durante la Segunda República en la década de los treinta fueron frenados y totalmente revertidos por cuarenta años durante la dictadura de Francisco Franco.

Como se demostrará en las siguientes reflexiones, el apoyo cultural para los derechos de las mujeres en España crecía a pasos agigantados durante la dictadura, incluso mientras las mujeres españolas sufrían injusticias imperdonables impuestas por Franco en cumplimiento con su visión de la mujer como figura sumisa y secundaria en la sociedad. Aunque los millones de proponentes de la igualdad para las mujeres se veían obligados a guardar silencio por el temor legítimo a represalias violentas por parte de la aparentemente omnipresente dictadura, la evolución de las normas culturales, debido en gran parte al contacto con turistas de otros países occidentales ya en pleno movimiento de liberalización, fueron tan evidentes que incluso Franco sintió la necesidad de al menos fingir interés en los derechos de las mujeres. Los gestos legislativos tímidos y superficiales mencionados anteriormente se produjeron antes de la muerte de Franco en aparente respuesta a presiones tanto nacionales como internacionales. Esta pequeńa ola de legislación, mayormente simbólica, presagió el cambio gigantesco que llegaría a España tras la muerte de Franco.

Casualmente, el fallecimiento de Franco se produjo once meses después del comienzo del Año Internacional de la Mujer (AIM) y la iniciativa de las Naciones Unidas llamada la Década para la Mujer. La democracia en España volvió en un momento en el que el mundo occidental había decidido unirse colectivamente para trabajar proactivamente para proteger y empoderar a las mujeres. Dado que muchos países habían aprobado leyes para la protección de los derechos de las mujeres en los años anteriores, España tuvo varios ejemplos claros de cómo rápidamente codificar constitucionalmente la igualdad de las mujeres y luego reforzar esas protecciones a través de legislación subsecuente más exhaustiva y explícita. Aunque es común y lógico que los movimientos de igualdad ganen impulso al comienzo de una democracia, la velocidad y minuciosidad con que España aprobó las leyes de derechos de las mujeres fue impresionante. Esta muy rápida transición sirve como prueba de que una gran mayoría de espańoles, forzados violentamente a guardar silencio durante décadas, habían anhelado la libertad, la democracia, y la igualdad. Tres años después de la dictadura, la aprobación unánime de las disposiciones sobre la igualdad 
de la mujer en la nueva Constitución progresiva llevó a España a la vanguardia del movimiento internacional para los derechos de la mujer y convirtió al país en el ejemplo más claro de la eficacia de la acción democrática colectiva.

Finalmente, a medida que han pasado las décadas, España ha consolidado su reputación como uno de los líderes mundiales de gobernación en términos de los derechos de las mujeres. Como se mostró con la ágil transición, el gobierno casi siempre está guiado por la cultura una vez que se establece la democracia. Sin embargo, en las primeras dos décadas del siglo XxI, el gobierno español ha tomado medidas afirmativas para combatir el azote cultural en curso de la violencia de género y el machismo. Debido a que esta legislación aún está en un estado inicial, se requerirán futuras investigaciones para determinar la eficacia de esta estrategia que invierte la relación tradicional entre el gobierno y la cultura.

\subsection{EL SUFRAGIO FEMENINO EN EL MUNDO OCCIDENTAL}

Aunque al final del siglo xvin se instituyó, de una forma muy limitada, con éxito en los Estados Unidos y se intentó con efectos desastrosos en Francia, la democracia no se hizo ampliamente popular en el mundo occidental hasta finales del siglo XIX y principios del xx. En este momento, los países de América y Europa establecieron una gobernación democrática a diversos grados y estructuras. En Europa, muchos monarcas mantenían su poder en papeles más ceremoniales, mientras que los líderes militares tenían un papel importante en la supervisión de los gobiernos semidemocráticos o pseudodemocráticos en América Central y América del Sur. Con muy pocas excepciones, el derecho al voto en estas nuevas democracias se limitaba a porciones de la población en función de muchos factores, como la raza, la propiedad de la tierra, la nobleza, la educación y, por supuesto, el sexo. Sin embargo, la porción de la población con el derecho al voto se daba cuenta rápidamente, y en la mayoría de los casos se veían obligados a darse cuenta, de que la inclusión de todos los ciudadanos en las decisiones de una sociedad es una faceta esencial de la propia naturaleza de la gobernación democrática. Pronto se hizo evidente en todo el Occidente que la democracia no podría mantenerse por mucho tiempo sin el pleno derecho de voto de todos sus ciudadanos. En otras palabras, parece que la democracia, inevitablemente, tiende a dar la bienvenida a todos. Teniendo esto en cuenta, los movimientos de sufragio femenino comenzaron en un país tras otro demandando su derecho al voto y sus derechos básicos como seres humanos.

El hecho desafortunado sobre la naturaleza acogedora de la democracia es que las mujeres, a menudo, han sido las últimas en recibir la bienvenida a participar. El derecho al voto se ha otorgado comúnmente en el siguiente orden: primero, los reyes y la nobleza, luego los terratenientes varones, entonces los hombres educados de alta estima en la sociedad, después generalmente los hombres blancos en el Occidente, luego los hombres de origen minoritario racial y étnico, y, finalmente, las mujeres, pero a menudo con restricciones en cuanto a edad, educación, y/o estado civil. Con el tiempo, los criterios para el votante se liberalizaban a medida que mayores porcentajes de la población exigían el derecho al voto. Lo que a veces 
era un proceso lento, históricamente se aceleraba, o en el caso de España, revertió, debido a macroeventos como las depresiones económicas o, como fue el caso en Inglaterra, una guerra.

Durante siglos, aunque los ingleses en general mantenían una apreciación cultural por la noción de los derechos individuales desde la Magna Carta Libertatum en 1215, el gobierno del país estaba dominado por los monarcas hasta que la Revolución inglesa del siglo XVir lo obligó a aceptar la democracia de forma limitada. Con la democratización de la información provocada por la imprenta de Gutenberg en el siglo xv, el Occidente comenzó su cuenta atrás hacia la gobernación democrática. Los movimientos que seguían como la Reforma Protestante y la Ilustración revolucionaban el carácter mismo de la sociedad europea. Aun así, los monarcas podían mantener su poder, casi total, en el continente hasta el siglo XIX. Aunque varios cuerpos legislativos, de una forma u otra, existían en Inglaterra durante siglos, estos cuerpos estaban formados por duques y otros nobles que aún respondían al monarca y actuaban en su nombre. La implementación exitosa de un gobierno representativo en los Estados Unidos en 1789, incluidas las prohibiciones explícitas de los títulos de nobleza, sirvió como ejemplo para el resto del Occidente de que era posible lograr una gobernación democrática. Con el ejemplo de su antigua colonia en mente, el pueblo de Inglaterra, empezando con los hombres terratenientes sin títulos de nobleza, comenzó a exigir el derecho a votar por su propia representación en el Parlamento. La presión del pueblo se hizo tan grande que el parlamento bajo el rey Guillermo IV sintió la necesidad de aprobar la Ley de Reforma de 1832, otorgando el derecho al voto a algunos terratenientes. Esta legislación marcó el punto en el que Inglaterra realmente comenzó su lenta marcha hacia la democracia. Durante la segunda mitad del siglo xix, surgían una serie de protestas y movimientos exigiendo el derecho al voto, pero sus peticiones fueron en vano ${ }^{95}$. No fue hasta que Inglaterra se encontró en medio de una crisis electoral provocada por la «Gran Guerra» que los manifestantes finalmente prevalecieron. Ya años después del comienzo de la Primera Guerra Mundial, el Parlamento inglés aprobó reformas electorales extensas en la Ley de Representación del Pueblo de 1918. Esta legislación fue necesaria debido a la gran cantidad de hombres con derecho a voto que estaban en el extranjero luchando en la guerra. No se produjo por voluntad democrática, sino por temor a un colapso total del sistema electoral. Con tan pocos votantes elegibles en el país en ese momento, los resultados de las elecciones habrían sido injustamente sesgados, pero tampoco había suficientes personas con la capacidad de administrar las elecciones en sí. La legislación eliminó las restricciones previas al derecho de voto relacionadas con la propiedad de los hombres de los veintiún años o más, y permitió una edad menor, los diecinueve, para los soldados que estaban en el extranjero para que pudieran votar en ausencia. Al dar a todos los hombres el derecho al voto, cambiaron por completo la noción inglesa de la participación democrática de una

95 Mitchell, J.C. (1976), «Electoral Strategy Under Open Voting: Evidence from England», 1832-1880, Public Choice, 28 (invierno), pp. 17-35. p. 18. 
relación de propiedad a un derecho básico de todos los seres humanos. Además, este cambio de mentalidad afirmó el argumento de las sufragistas feministas, que también ganaron el derecho al voto con esta ley, aunque con serias restricciones sobre la edad, treinta en lugar de veintiuno, y restricciones basadas en si una mujer ocupaba su propio hogar ${ }^{96}$. Las sufragistas feministas, que formaron una parte clave del éxito de Inglaterra durante la Primera Guerra Mundial, no estaban satisfechas con este progreso, dado que los nuevos estándares seguían concretizando la desigualdad en ley. Continuaban solicitando al gobierno y protestando hasta que las restricciones electorales a las mujeres inglesas fueron eliminadas por completo por el gobierno conservador de Stanley Baldwin, que aprobó en el Parlamento la Ley de Igualdad del Derecho al Voto de $1928^{97}$. Así como la Primera Guerra Mundial se convirtió en el catalizador final para el derecho al voto femenino en Inglaterra, esta misma guerra sirvió como el argumento final para las sufragistas feministas en los Estados Unidos, también.

El servicio al país de las mujeres trabajadoras durante la Primera Guerra Mundial dejó al gobierno estadounidense sin otra opción que aprobar el sufragio femenino con la ratificación de la Enmienda XIX a la Constitución en agosto de 1920, pero esta victoria solo llegó después de décadas de manifestaciones y un proceso gradualista parecido al de los ingleses. Como no había reyes ni títulos de nobleza en la República estadounidense, el sufragio se limitó originalmente a los terratenientes blancos y varones. Aunque a la mayoría de los estadounidenses todavía no se les permitía votar durante el primer siglo de existencia del país, la primera enmienda a la Constitución les garantizaba el derecho a la libertad de expresión. A su vez, la conversación política colectiva durante este tiempo estaba dominada más por un tema que por cualquier otro, el de la abolición de la esclavitud ${ }^{98}$. La institución de la esclavitud, el "pecado original» del país, se convirtió en un tema tan divisivo que, para detener su expansión en los territorios recientemente establecidos en el oeste, Estados Unidos entró en su única guerra civil. Después de varios años de batallas brutales y cientos de miles de muertes, la guerra culminó con una victoria para el norte abolicionista y la aprobación de varias enmiendas constitucionales que liberaron a las personas esclavizadas y les otorgó a estos esclavos recién liberados los mismos derechos que los ciudadanos, siempre y cuando esas personas eran hombres. Las tres enmiendas aprobadas en los años posteriores a la guerra fueron la Enmienda XIII, que liberó a todos los esclavos en 1865; la Enmienda XIV, que confirió la igualdad de derechos como ciudadanos a los esclavos liberados en 1868; y la Enmienda xv, que otorgó el sufragio a los exesclavos recién liberados en 1870 . Como a menudo era el caso de la Constitución estadounidense, el lenguaje de estas

${ }^{6}$ Ogg, F.A. (ago. 1918), "The British Representation of the People Act.», The American Political Science Review, 12(3), pp. 498-503.

${ }_{97}$ Takayanagi, M. (2019), “"Does the right hon. Gentleman mean equal votes at 21?” Conservative women and equal franchise, 1919-1928", Women's History Review, 28(2), pp. 194-214. p. 194.

${ }^{98}$ La Constitución de los Estados Unidos de América (1787), Archivos Nacionales de los Estados Unidos de América. https://www.archives.gov/espanol/constitucion. 
enmiendas se redactó de manera deliberadamente amplia para establecer una base legal para los derechos de ciudadanía sin limitar esos derechos con demasiada especificidad. En parte, la Enmienda XIV decía: «Todas las personas nacidas o naturalizadas en los Estados Unidos y algunas veces a su jurisdicción son ciudadanos de los Estados Unidos y de los Estados en que residen». Esta enmienda se refería a "personas» sin referencia específica al sexo. Además, la Enmienda Xv decía lo siguiente: «Ni los Estados Unidos, ni ningún otro Estado, pueden desconocer ni menoscabar el derecho de sufragio de los ciudadanos de los Estados Unidos por motivo de raza, color o de su condición anterior de esclavos». Debido a que este lenguaje era tan amplio, estas dos enmiendas se convirtieron inmediatamente en el argumento principal para el sufragio femenino.

El 5 de noviembre de 1872, dos años después de la ratificación de la Enmienda xv, la famosa sufragista Susan B. Anthony, que había viajado por el país durante décadas dando discursos a favor de la igualdad de derechos para las mujeres, fue a las urnas y votó. Con este simple acto, ella causó una gran controversia en la ciudad y, tres semanas después, fue arrestada por el delito de votar siendo una mujer. Durante el juicio, Anthony propuso el argumento conciso de que la Enmienda XIV se refería a todas las "personas» como ciudadanos, no solo a los hombres. Por lo tanto, las mujeres estadounidenses eran claramente ciudadanas y tenían sufragio de acuerdo con la Enmienda Xv. Sin mucha explicación para su veredicto, el juez decidió que Anthony era culpable del crimen de haber votado siendo mujer y la castigó con una multa de $\$ 100$, igual a aproximadamente $2000 €$ cuando se ajusta por inflación. Anthony declaró que nunca pagaría un duro de una multa tan injusta y, entendiendo las probables consecuencias políticas y sociales, el juez la dejó libre sin haber pagado un céntimo ${ }^{99}$. Después del juicio, Susan B. Anthony continuaba viajando por el país dando discursos y escribiendo artículos a favor del sufragio femenino. Aunque lamentablemente falleció catorce años antes de que su sueño de sufragio universal se hiciera realidad, sus palabras, y las de muchas otras sufragistas, no cayeron en oídos sordos. Varios estados recién fundados en el oeste del país aprobaron el sufragio femenino en las siguientes décadas. Primero Colorado en 1893, luego Washington y California en 1910 y, finalmente, cuando el movimiento volvió al este del país, el estado liberal de Nueva York lo aprobó en 1917, solo tres años antes de que se aprobara el sufragio completo a nivel nacional mediante la ratificación de la Enmienda XIX a la Constitución en 1920. En el caso de los Estados Unidos, el sistema federal descentralizado tenía un efecto positivo para el movimiento por los derechos de las mujeres. Sin embargo, en otros países occidentales, este no era siempre el caso.

Debido en gran parte a su sistema descentralizado, Suiza tiene el curioso deshonor de no haber logrado completamente el sufragio femenino hasta noviembre de 1990. Los hombres suizos recibieron el sufragio universal a través de una

99 Ritchie, J. y Ronald, K. (eds.) (2001), Available Means: An Anthology of Women's Rhetoric(s), Pittsburgh, University of Pittsburgh Press, pp. 151-156. 
enmienda constitucional en 1848, aunque podían votar antes en muchas áreas del país. Mientras pasaban las décadas, el sistema suizo funcionaba de una forma muy democrática, al menos desde la perspectiva de los hombres, ya que celebraban referéndums sobre importantes asuntos nacionales, cantonales y municipales. En 1910, movimientos de sufragio femenino comenzaron a nivel municipal y cantonal, pero ni siquiera hubo una conversación sobre el sufragio femenino en el Parlamento suizo hasta 1944. En ese momento, el tema se mencionaba de vez en cuando a nivel nacional, pero el gobierno federal anunció en 1951 que era demasiado pronto para celebrar un referéndum sobre el sufragio femenino. Durante la década de los cincuenta, los cantones empezaron a aprobar derechos de voto limitados para las mujeres, lo que llevó a los líderes políticos a pensar que había llegado el momento para un referéndum nacional. En 1959, los hombres del país se reunieron en las plazas de cada ciudad para participar, no por votación secreta sino por aclamación pública delante de las mujeres suizas, y votaron abrumadoramente, dos hombres en contra para cada hombre a favor, en contra del sufragio femenino. En todo el Occidente, la década de los sesenta fue una década turbulenta de manifestaciones enormes y exitosos movimientos de justicia social. Se estaba produciendo un cambio transcendental hacia la protección de los derechos de todos los seres humanos, y en 1968 los países europeos se unieron para firmar una declaración de derechos en la Convención Europea de Derechos Humanos. Este fue un documento que el gobierno suizo no pudo apoyar sin agregar excepciones para excluir los derechos políticos de las mujeres. Indignados y en un estado de shock, los partidarios del sufragio femenino en toda Europa se unieron a los sufragistas suizos para presionar al Parlamento para que finalmente otorgue a las mujeres el derecho al voto. La presión fue tan grande que solo tres años después, el 7 de febrero de 1971, los hombres del país votaron, esta vez dos hombres a favor para cada hombre en contra, aprobar el sufragio femenino. Aunque este fue un momento emocionante para las mujeres del país, no fue una victoria completa. El referéndum todavía permitió a los cantones decidir sus propias reglas de votación para las elecciones locales y para una cámara del Parlamento nacional. Cuatro cantones decidieron mantener prohibiciones al sufragio femenino, dos de ellos eliminaron estas prohibiciones en 1983. Pasaron más años hasta que el cantón de Appenzell Ausserrhoden aprobó el sufragio femenino en 1989 y Appenzell Innerrhoden finalmente trajo el sufragio universal a Suiza el 27 de noviembre de $1990^{100}$. Dada su reputación como un país progresista e iluminado, este aspecto desafortunado de su historia puede ser sorprendente a muchas personas. Por otro lado, el estereotipo de España como un país conservador y atrasado puede necesitar revisión, dado el hecho de que aprobó dos veces el sufragio femenino sin restricción ninguna décadas antes de que los suizos reconocieran este derecho humano básico.

100 Banaszak, L.A. (1996), Chapter Title: Comparing the U.S. and Swiss Woman Suffrage Movements, Why Movements Succeed or Fail: Opportunity, Culture, and the Struggle for Woman Suffrage (pp. 3-20), Nueva Jersey, Princeton University Press. 
En 1931, en los inicios de la naciente República española, cuando se debatieron las disposiciones sobre el sufragio femenino de la nueva Constitución, la decisión de los progresistas se centró en un debate entre ideología y practicidad. Muchas feministas y partidarios acérrimos del sufragio femenino se preocupaban de que habría consecuencias prácticas serias si les dieran a las mujeres españolas el derecho al voto. Hablando del punto de vista feminista, dijo Margarita Nelken en su libro La mujer ante las Cortes Constituyentes (1931), "facilitarle el voto a la mujer suponía darle votos a las fuerzas conservadoras. Desde su argumentación, "darle derechos a un colectivo no significaba necesariamente actuar a favor del conjunto de la sociedad... Las mujeres españolas realmente amantes de la libertad han de ser las primeras en posponer su interés propio al progreso de España"». Las fuerzas progresistas, con quienes Nelken se identificó, temían que las esposas de los hombres conservadores, especialmente en las zonas rurales del país, simplemente votaran como les dijeron sus esposos. Serían esposas obedientes y sumisas de acuerdo con sus creencias católicas. Muchas mujeres progresistas favorecían un periodo durante el cual a las mujeres no se les permitiría votar, sino que tendrían tiempo para ser generalmente educadas, casi el cuarenta por ciento de las mujeres españolas en 1930 de diez años o más eran analfabetas, y también culturalmente informadas de sus derechos ${ }^{101}$. Fue una decisión difícil que muchas feministas progresistas, como Victoria Kent, lamentaron tener que tomar: "Creo que no es el momento de otorgar el voto a la mujer española. Lo dice una mujer que, en el momento crítico de decirlo, renuncia a un ideal. Al expresarme así hago renuncia de mi ideal femenino, pero así requiero la salud de la República». Por otro lado, hubo muchas sufragistas feministas que se negaron a renunciar a sus ideales en lugar de la practicidad política: "Clara Campoamor contestó a estos argumentos críticos en la defensa del carácter indiscutible del sufragio femenino, si se partía en la nueva organización política del principio de igualdad como derecho universal, con independencia de si sus resultados electorales eran oportunos o no. Su defensa fue de carácter ideológico y ético, y radicalmente democrática» ${ }^{102}$. Al final, el sufragio femenino se aprobó como una disposición de la Constitución de la Segunda República española. Durante los siguientes años, los temores de muchas feministas progresistas se hicieron realidad a medida que los partidos conservadores ganaron varias elecciones, y las visiones increíblemente divergentes del país se convirtieron en tumultos violentos. Una situación muy parecida había confrontado a los redactores de la Constitución estadounidense con respecto al tema de la esclavitud. Muchos estaban en contra de la esclavitud y querían prohibirla en la Constitución como una afirmación de los derechos de todos los seres humanos. Sin embargo, sabiendo que los estados del sur no firmarían una Constitución que prohibiera la esclavitud, el

101 Viñao Frago, A. (Winter 1990), «The History of Literacy in Spain: Evolution, Traits, and Questions», History of Education Quarterly, 30(4), pp. 573-599. p. 584.

102 Aguado, A. (2005), «Entre lo público y lo privado: sufragio y divorcio en la Segunda República», Ayer, 60, pp. 105-134. p. 116. 
resto de los estados favoreció la practicidad sobre la ideología, temiendo que, como estados divididos, pronto serían conquistados por países europeos poderosos. Siete décadas después, esta decisión llevó al país a su única guerra civil. Aunque es un tema muy debatido, algunas académicas proponen el argumento de que, en el caso de España, la decisión contraria a favorecer el principio sobre la practicidad fue una de las causas de la guerra civil española ${ }^{103}$. Con el establecimiento de la dictadura de Francisco Franco, las mujeres de España no votarían otra vez de una forma verdaderamente libre durante cuatro largas décadas.

\subsection{LA REPRESIÓN DE LAS MUJERES EN LA ESPAÑA FRANQUISTA}

Durante los cinco años de la Segunda República española, España descubrió lo que sucede a menudo en muchos países que no están acostumbrados a la gobernanza democrática, que la libertad crea derechos e igualdad, pero también puede ser desordenada y caótica. Esta desafortunada realidad se desarrolló en la República española, ya que estos años se vieron empañados por la violencia entre facciones y elecciones disputadas. Utilizando el desorden natural de la nueva democracia como una excusa para imponer su versión fascista de la ley y el orden, el general Francisco Franco estableció una dictadura en 1939 después de tres años de sangrienta guerra civil. Durante los primeros años del franquismo, las fuerzas de la dictadura asesinaron indiscriminadamente a miles de ciudadanos españoles como medio para eliminar la oposición ideológica y generar temor en sus opositores políticos restantes. El horror de las fosas comunes aún sin descubrir es el triste legado de esta época. La violencia de Franco se dirigió contra hombres y mujeres por igual, pero después de la «limpieza» política de los primeros años de su dictadura, su enfoque totalitario se volvió hacia la imposición de sus creencias sociales represivas sobre las mujeres.

La España de los años cuarenta fue marcada por la institucionalización sistemática de una visión sexista y religiosa del papel de la mujer en la sociedad. Franco creía que las mujeres debían cumplir con las normas de género católicas y subordinarse por completo al hombre. Según su ideología, las mujeres no eran consideradas ciudadanas, ni siquiera seres humanos en muchos casos: «La subordinación de la mujer al hombre era total. Las tres funciones que tenía asignadas -madre, esposa y ama de casa- representaban la expresión máxima de la feminidad $»^{104}$. Al igual que otros dictadores fascistas europeos del siglo xx, Franco estaba obsesionado con la idea del cuerpo sano de la mujer como necesidad para ejercer un estado centralizado. Con esto en mente, Franco empleó a la Sección Femenina para crear periódi-

${ }_{103}$ Wyoming Fees, E. (2007), Making Women Matter: Spain's Long Road Toward Gender Equality, Chapel Hill, University of North Carolina. pp. 6-7.

104 Pelka, A. (2014), «Mujer e ideología en la posguerra española: feminidad, cuerpo y vestido", Historia Social, 79, pp. 23-42. p. 27. 
cos y revistas propagandizadas para inculcar a las mujeres españolas el mensaje de que el mantenimiento de un cuerpo sano es una parte clave de su servicio al país:

Según Foucault, en las sociedades modernas la forma represiva del poder se centra en la 'administración del cuerpo', incluyendo su formación y su control... Siguiendo Foucault, a causa de esta bio-politica la mujer era percibida en relación a su cuerpo, transmisor además de los valores del régimen. Se promovía un cuerpo sano y funcional, paradigma de la 'raza' y al servicio de la nación por media de dicha función procreadora ${ }^{105}$.

La "administración del cuerpo» no era solo una estrategia política de un gobierno fascista a nivel macro, sino la reducción de las mujeres como seres humanos a sus funciones biológicas, una eliminación de la humanidad de las mujeres a nivel psicológico y emocional. En la España franquista, las mujeres fueron bombardeadas constantemente con el mensaje de que su importancia no solo era servir como máquinas biológicas irreflexivas para el estado, sino que deberían estar agradecidas por este papel en la sociedad: «La verdadera misión de la mujer es dar hijos a La Patria. Y esto es, por lo tanto, su suprema aspiración» ${ }^{106}$. La ideología del régimen franquista con respecto a las mujeres lo llevó a eliminar casi totalmente los derechos legales de las mujeres, así como a establecer una serie de leyes sobre las relaciones familiares que desgarraron la estructura misma de la sociedad. Las leyes aprobadas por la dictadura en el Código penal de 1944 sobre violación y adulterio convirtieron la tragedia personal de las mujeres españolas en profundas injusticias sociales. Por ejemplo, "las leyes penales franquistas asimilaban las mujeres a los incapaces y además sólo daban protección a las mujeres que eran consideradas "honestas", ya que si no lo eran, eran tratadas como un simple objeto, a disposición del varón, quien podía incluso llegar a violar a su mujer sin temor a ser sancionado penalmente» ${ }^{107}$. La falta de castigo legal para un esposo que abusó violentamente a su esposa es lo que Marta Borraz llamó «la doble represión de Franco sobre la mujer» ${ }^{108}$. El sufrimiento emocional personal de una mujer violada se multiplicó por el sello de aprobación del gobierno de las horribles acciones del hombre. La disposición del Código penal de 1944 sobre el adulterio es otro ejemplo de esta doble represión. Si una mujer casada cometiera adulterio de cualquier manera o en cualquier lugar, no solo sería penalizada con una pena de prisión menor, sino que el matrimonio podría declararse nulo. Si un hombre casado cometió adulterio, se agregaron dos condiciones para exculparlo de su culpabilidad. Mientras el hombre tuviera su relación extramarital fuera del hogar conyugal y no lo hiciera "notoriamente», es decir, si lo hiciera

105 Ibidem, p. 25.

106 Ibidem, p. 25.

107 Moraga García, M.A. (dic. 2008), «Notas sobre la situación jurídica de la mujer en el franquismo", Feminismo/s, 12, pp. 229-252. p. 240.

108 Borraz, M., «La doble represión de Franco sobre la mujer», ElDiario.es. https://desmemoria.eldiario.es/represion-mujeres/. 
discretamente, no podría ser legalmente responsable de adulterio. La institucionalización de protecciones legales tan desiguales fue en contra de todos los conceptos modernos de moralidad y contra la naturaleza humana misma. Aunque no podían afectar el cambio legislativo durante el régimen franquista, tener que soportar tales injusticias durante varias décadas provocó un cambio importante en el sentimiento cultural con respecto a la igualdad de las mujeres en Espańa. Después de la muerte de Franco, motivó a las mujeres espańolas a exigir cambios, y motivó a los hombres españoles a apoyar la causa de la igualdad de las mujeres.

Durante la década de los sesenta, se hizo evidente que Franco sentía presión a nivel nacional por un cambio de sentimiento público en su país y, además, las democracias occidentales internacionales empezaron a codificar su liberalización cultural. A principios de la década, Franco aprobó legislación supuestamente sobre los derechos de las mujeres en la Ley del 22 de julio de 1961, «la mencionada Ley recogió el principio de la igualdad de derechos laborales de los trabajadores de ambos sexos, si bien estableció excepciones significativas» ${ }^{109}$. Estas excepciones significativas incluían una amplia parte del poder gubernamental del país, como juez, fiscal, y la gran mayoría de los puestos en las fuerzas armadas. Aunque estos cambios fueron en gran medida simbólicos y superficiales, es digno de mención que Franco sentía que era necesario al menos seńalar que apoyaba un movimiento afirmando los derechos de las mujeres. Estos cambios a la ley española iban en contra de su visión sexista y demostraron que incluso Franco reconocía que un movimiento hacia la igualdad era inevitable. Además del cambio en el sentimiento cultural debido a décadas viviendo bajo leyes injustas, la dependencia económica de Franco con el turismo hizo que la población de España tuviera un intercambio cultural con ciudadanos de países más liberales todos los días. En las décadas de los cincuenta y los sesenta, la estrategia de crecimiento económico de Franco dependía en gran medida de la floreciente industria del turismo. El número de turistas extranjeros visitando España pasó de solo 20000 en 1940 a 460000 en 1950, a 4,33 millones en 1960, y luego a 21,27 millones en 1970. Estas cifras representan un aumento asombroso de 4,624\% en las dos décadas de 1950 a $1970^{110}$. Los millones de turistas que Franco quería para estimular la actividad económica también trajeron millones de interacciones con los españoles a diario. Aunque todavía hay debate sobre el grado de liberalismo en la cultura espańola durante la Segunda República, no hay duda de que la economía de Franco irónicamente movió la cultura a favorecer a los derechos de las mujeres, tanto que la cultura española apoyó completamente la igualdad para las mujeres en el momento en que murió Franco. Además, dado que las mujeres sufrían tanto bajo el franquismo, es apropiado que el año de su muerte, 1975, fuera declarado por las Naciones Unidas como el Año Internacional de la Mujer.

109 Valiente Fernández, C. (1998), «La liberalización del régimen franquista: la Ley de 22 de Julio de 1961 sobre los derechos Políticos, profesionales y de trabajo de la mujer», Historia Social, 31, pp. 45-65. p. 45.

${ }_{110}$ Vallejo Pousada, R. (2015), «¿Bendición del cielo o plaga? El turismo en la España franquista, 1939-1975», Cuadernos de Historia Contemporánea, 37, pp. 89-113. p. 92. 


\subsection{LA INFLUENCIA INTERNACIONAL EN LA LEGISLACIÓN ESPAÑOLA SOBRE LOS DERECHOS DE LAS MUJERES DESPUÉS DE FranCo}

Tras la muerte de Franco, España se apresuró a establecer un gobierno representativo y estructurar una Constitución justa que incluyera la protección de los derechos de todos los ciudadanos. En la década y media anterior a la redacción de la Constitución española de 1978, varios países occidentales habían aprobado legislación importante sobre la igualdad y los derechos de la mujer, dando a los españoles un resumen detallado de las disposiciones necesarias para garantizar la igualdad. Además, se estaba formando un esfuerzo internacional concertado para reconocer y promover una visión de las mujeres empoderadas, y para proteger los derechos de las mujeres instando a las legislaturas a aprobar las leyes de derechos de las mujeres.

En 1975, las Naciones Unidas comenzó un proyecto de diez años para promover y proteger a las mujeres en todo el mundo. La ONU declaró a 1975 el Año Internacional de la Mujer. Luego estableció el 8 de marzo como el Día Internacional de la Mujer, una celebración anual de las mujeres y sus logros sociales, económicos, políticos y culturales. Finalmente, la ONU anunció su proyecto llamado la Década para la Mujer. Este proyecto estableció objetivos elevados en su conferencia inicial en la Ciudad de México en 1975, evaluó y actualizó esos objetivos en una reunión en Copenhague en 1980, y examinó los resultados y estableció objetivos futuros durante su convención final en Nairobi en 1985. Esta década crucial culminó con la ratificación por 170 naciones en 1985 de la Convención de las Naciones Unidas sobre la eliminación de todas las formas de discriminación contra la mujer. Los documentos ratificados incluían disposiciones para la inclusión de «departamentos para mujeres» y el nombramiento de ministras en todas las organizaciones internacionales, la continuación del aumento de la sensibilización colectiva con respecto a los problemas de las mujeres a través de mujeres empoderadas en imágenes en los libros de texto y mensajes positivos hacia las mujeres en todos los planes de estudio educativos y, finalmente, una Declaración de los Derechos de la Mujer junto con un Pacto para proteger esos derechos ${ }^{111}$. Durante la Década para la Mujer, numerosos países, España incluido, aprobaron legislación amplia sobre los derechos de las mujeres, demostrando que la acción colectiva a nivel macro puede, de hecho, producir un cambio positivo.

Al elaborar su nueva Constitución, España no solo contó con el apoyo de las Naciones Unidas y la comunidad internacional, sino que tuvo la ventaja de aprender de los ejemplos establecidos por las leyes sobre los derechos de las mujeres que ya se habían aprobado en otros países occidentales. Los constituyentes españoles no tenían que reinventar la rueda y ciertamente no lo hicieron. Dado que el lenguaje final de los artículos relacionados con la igualdad de las mujeres en la Constitu-

111 Zinsser, J.P. (nov. 1990), «The United Nations Decade for Women: A Quiet Revolution", The History Teacher, 24(1), pp. 19-29, pp. 20-22. 
ción española de 1978 es sorprendentemente similar al de la legislación anterior de otros países, uno debe inferir que los constituyentes españoles fueron muy influenciados por sus homólogos extranjeros. Por ejemplo, las disposiciones de igualdad de la Constitución italiana de 1947 dicen lo siguiente:

Art. 3: Todos los ciudadanos tendrán la misma dignidad social y serán iguales ante la ley, sin distinción de sexo, raza, lengua, religión, opiniones políticas ni circunstancias personales y sociales. Constituye obligación de la República suprimir los obstáculos de orden económico y social que, limitando de hecho la libertad y la igualdad de los ciudadanos, impiden el pleno desarrollo de la persona humana y la participación efectiva de todos los trabajadores en la organización política, económica y social del país.

Art. 37: La mujer trabajadora tendrá los mismos derechos y, a igualdad de trabajo, la misma retribución que el trabajador. Las condiciones de trabajo deberán permitir a la mujer el cumplimiento de su misión familiar esencial y asegurar a la madre y al niño una protección especial adecuada ${ }^{112}$.

El lenguaje de la Constitución italiana de 1947 es casi idéntico a partes de la ley de Derechos Civiles de 1964 en los Estados Unidos, y casi se copian y pegan palabra por palabra luego en el Artículo 14 de la Constitución española de 1978. Aunque las protecciones constitucionales transmiten seriedad y permanencia, España volvería a seguir el ejemplo de sus vecinos occidentales al agregar un lenguaje más específico y aplicable en la legislación de los años siguientes.

$\mathrm{Al}$ aprobar la Ley de Igualdad Salarial en 1963 y la extensa Ley de Derechos Civiles de 1964, Estados Unidos comenzó la tradición occidental de aprobar una serie de leyes de igualdad de derechos específicos y numerosos. Aunque el partido republicano había intentado aprobar una serie de leyes de igualdad racial durante la década de los cincuenta, fueron impedidos cada vez por los demócratas racistas del sur, conocidos coloquialmente como los Dixiecrats. Con la llegada del progresista presidente Kennedy en 1960, la legislación sobre igualdad racial y del sexo se convirtió en una prioridad compartida para ambos partidos. Los dos partidos trabajaron juntos para redactar una legislación detallada y aprobaron la Ley de Igualdad Salarial de 1963 con una abrumadora mayoría de aprobación del 97,6\%. Todos los republicanos presentes votaron a favor y solo nueve demócratas votaron en contra de la igualdad salarial para las mujeres trabajadoras. Siguiendo el ejemplo de los Estados Unidos, el Reino Unido aprobó su Ley de Igualdad Salarial en 1970 y la Ley de Discriminación Sexual en $1975^{113}$ y Francia, estableciendo disposiciones similares a las de los Estados Unidos y el Reino Unido, aprobó legislación sobre la

112 Constitución de la República Italiana (27 dic. 1947), Consejo Económico y Social de España. http://www.ces.es/TRESMED/docum/ita-cttn-esp.pdf.

${ }_{113}$ Ross, J. (2010), 10 Discrimination, Employment Law Essentials (pp. 163-200), Edinburgh, Edinburgh University Press, p. 164. 
igualdad salarial en diciembre de $1972^{114}$. En todos estos países, estas políticas han sido muy difíciles de aplicar y, por lo tanto, leyes más estrictas de igualdad salarial han sido objeto de mucho debate hasta la actualidad.

Debido a su tradición de valorar mucho la propiedad privada y la preferencia histórica para los derechos negativos en la legislación, Estados Unidos no llegó a muchas disposiciones de derechos afirmativos que luego se agregaron a la serie de leyes en muchos países europeos. Aunque EE. UU. estableció Medicare y Medicaid en 1965, opciones públicas para el seguro médico, la mayoría de los estadounidenses todavía obtienen su seguro médico a través de sus empleadores, que a menudo son empresas privadas. Debido a este dominio privado del mercado de sanidad, aún no se ha instituido la baja por maternidad remunerada con legislación federal. Sin embargo, Europa es y ha sido más abierta culturalmente y políticamente a la intervención pública, este problema se resolvió hace mucho tiempo. En Francia, por ejemplo, el debate se centró menos en si una solución socializada era aconsejable y más en cómo mantener la igualdad judicial cuando se trata de un derecho afirmativo directamente relacionado con la biología de las mujeres. Dorothy McBride Stetson explicó el debate en su libro Los derechos de las mujeres en Francia, diciendo que incluso en el nuevo clima de la ley de igualdad de oportunidades en el empleo, la baja por maternidad remunerada sigue siendo una parte central de la política laboral francesa, mientras que en los Estados Unidos las leyes de igualdad en el empleo han desplazado la baja por maternidad como tal. Las mujeres empleadas en Francia hoy tienen derecho por ley a una baja por maternidad pagada de catorce semanas. De hecho, en 1975, bajo Giscard, se fortalecieron las protecciones para el embarazo y la maternidad. Sin embargo, en 1977, una medida patrocinada por el gobierno para la baja por maternidad adicional para las madres fue cuestionada por opositores que preferían hacerla una baja "parental», disponible también para los padres, y esta solución prevaleción ${ }^{15}$. La baja por maternidad remunerada fue solo uno de los temas que se abordaron en una larga serie de leyes de derechos de la mujer aprobadas en Francia de 1965 a 1985. Cada política que afectaba a las mujeres, desde la reproducción hasta la jubilación, fue reescrita durante estas dos décadas ${ }^{116}$. Antes de casi todos los otros países con respecto a este tema, España ha obligado legalmente a la baja por maternidad remunerada de una forma u otra desde $1930^{117}$.

Aunque el progreso para las mujeres españolas fue interrumpido por cuarenta años de dictadura violenta, el país se apresuró a constitucionalizar y legis-

114 Van der Vleuten, A. (2016), The Price of Gender Equality: Member States and Governance in the European Union, New York: Routledge. (Originalmente publicado en 2007, Farnham, Reino Unido, Ashgate), p. 80.

115 Offen, K. (1990), Book Review: Women's Rights in France by Dorothy McBride, Constitutional Commentary, 7(130), pp. 130-136, p. 135.

116 Ibidem, p. 131.

117 Espuny Tomás, M.J. (2006), Los antecedentes históricos al permiso de lactancia, IUS Labor, 2, p. 3. 
lar protecciones de igualdad de derechos para las mujeres al mismo tiempo que la mayoría del resto del mundo occidental. Apenas tres años después de la muerte de Franco, España aprobó el sufragio universal sin restricciones dentro de un sistema verdaderamente democrático, así como amplias protecciones de los derechos de las mujeres. La velocidad y la relativa facilidad con que España aprobó estas leyes mostraron que una gran mayoría de la población española apoyaba la igualdad para las mujeres y no estaba de acuerdo con la visión de Franco para el país. Los españoles se vieron obligados a guardar silencio, reprimidos durante décadas, pero tan pronto como la democracia volvió a España, rápidamente el país se convirtió en uno de los líderes mundiales con respecto a la legislación sobre los derechos de las mujeres, aprobando tales medidas aproximadamente al mismo tiempo que la mayoría del Occidente, e incluso antes de algunos países, como Australia, que no aprobó su Ley de Discriminación por Sexo hasta 1984. En una democracia, una cultura a menudo cambia mucho antes que el gobierno, pero el progreso en España se detuvo debido a la dictadura. Ya sea debido a una reacción visceral y moral a las leyes injustas del franquismo o al contacto personal con millones de turistas más liberales, está claro que la cultura española no aceptó el franquismo y anhelaba la igualdad y la libertad después de la opresión de Franco. En otras palabras, España no era Franco y Franco no era España.

\section{CONCLUSIONES}

Después de un análisis exhaustivo de la evolución de la legislación sobre los derechos de las mujeres dentro del contexto más amplio del movimiento de igualdad de las mujeres de Occidente, parece que existen razones para ser optimistas sobre el futuro de la igualdad y el empoderamiento de las mujeres. Los resultados de esta investigación también indican que puede ser el momento de revisitar la memoria histórica sobre la cultura española. Dos veces durante el siglo pasado, España llegó a establecer una gobernanza democrática y, en ambas ocasiones, el país avanzó rápidamente e inequívocamente hacia la igualdad de los sexos. Esta observación debería alentar a todo el mundo sobre el posible progreso futuro de tal país. Aun así, la igualdad ante la ley no siempre equivale a la igualdad práctica en la sociedad. Los medios españoles hacen bien en arrojar luz sobre el grave problema del feminicidio por violencia doméstica, pero muchas otras mujeres sufren de otras formas comunes del maltrato. Por ejemplo, la pareja les impide ver a la familia o tener relaciones con amigos, insultos o amenazas, decide las cosas que puede o no hacer, insiste en tener relaciones sexuales aunque no tienen ganas, o a veces produce miedo por su comportamiento agresivo ${ }^{118}$.

118 Osborne, R. (2009), Apuntes sobre la violencia de género, Barcelona, Edicions Bellaterra, pp. 94-95. 
Con problemas sociales como estos que aún perviven en España, el gobierno español tomó medidas proactivas al aprobar las leyes orgánicas de 2004 y 2007 en un intento por resolver estas cuestiones. Como se mencionó anteriormente, el orden normal en democracia es que la cultura cambie primero y luego solicite al gobierno que promulgue esos cambios legislativamente. Sin embargo, la estrategia de las leyes orgánicas invierte esta relación con el objetivo de lograr en mayor medida la igualdad práctica en la sociedad española. Como Juan José Solozábal Echavarría escribió sobre el tema en 2013:

La igualdad, además, es una aspiración irrenunciable del constitucionalismo y ocupa un lugar central en el Estado social como forma política de nuestros días, que se propone intervenir en la marcha de la sociedad y corregir las desigualdades e injusticias que se dan en ella... Desde el punto de vista individual el Estado moderno es una comunidad jurídica de iguales, que no tolera la desigualdad jurídica personal, pues la igualdad es una exigencia del reconocimiento de la dignidad de todos ${ }^{119}$.

El éxito de un proyecto que busca reconocer la dignidad de todos sus ciudadanos es vital no solo para la seguridad y el bienestar de las mujeres que sufren directamente este problema, sino para la salud de una democracia que funcione:

La construcción de una sociedad igualitaria y libre de violencia no es algo que pueda hacerse a 'coste cero', la igualdad precisa de una inversión que permita abordar el cambio implicando a toda la sociedad, porque la igualdad es la base de la democracia y la violencia de género cuestiona la misma democracia. Mientras las mujeres sigan siendo asesinadas por el hecho de ser mujeres, no se puede hablar de democracia sin abrir debates sociales, políticos y económicos para cuestionar el patriarcado, como sistema económico y político ${ }^{120}$.

Las leyes orgánicas de 2004 y 2007 son emblemáticas del reconocimiento del gobierno español de la necesidad de estos debates. Es demasiado pronto para saber si estas políticas proactivas y una relación invertida entre el gobierno y la cultura serán efectivas, pero hay algunos indicadores de que la sociedad se está moviendo en la dirección correcta. Aunque el número de mujeres asesinadas por la violencia doméstica en España ha disminuido solo marginalmente en los últimos ańos, el número de denuncias totales y denuncias presentadas por terceros ha aumentado dramáticamente desde $2015^{121}$. Esto sirve como prueba de una creciente conciencia sobre los derechos y el bienestar de las mujeres, pero futuras investigaciones tendrán que

119 Solozábal Echavarría, J.J. (2013), Capitulo segundo: la garantía de la igualdad. Los derechos fundamentales: La vida, la igualdady los derechos de libertad, García Guerrero, J.L. (dir.), Valencia, Tirant lo Blanch, pp. 75-76.

120 Tajahuerce Ângel, I. y Ramírez Rico, E. (2018), La intervención en violencia de género desde diversos ámbitos, TAMaYo, J.J. (dir.), Madrid, Dykinson, S.L. p. 17.

${ }^{121}$ Violencia de género -datos y estadísticas-. (25 nov. 2019). epdata. https://www.epdata. es/datos/violencia-genero-estadisticas-ultima-victima/109/espana/106\#. 
determinar la eficacia a largo plazo de estas leyes. Finalmente, como lo demostró este análisis, la acción colectiva a escala internacional ha funcionado para abordar problemas parecidos en el pasado y, por lo tanto, puede ser una estrategia efectiva en la búsqueda de soluciones en el futuro.

ReCibido: 01-05-2020; ACEPTADo: 29-06-2020 



\title{
COMENTARIOS SOBRE LA INSULARIDAD DE LA GRACIOSA EN EL NUEVO ESTATUTO DE AUTONOMÍA DE CANARIAS
}

\author{
Noel Armas Castilla \\ Universidad de Sevilla
}

\section{RESUMEN}

El nuevo Estatuto de Autonomía de Canarias ha introducido una serie de cuestiones de gran interés para el Derecho administrativo. El objeto en el que se centra este artículo es la consideración estatutaria de La Graciosa como una «isla» contra la anterior denominación de «islote». Este nuevo estatus debe ser estudiado para conocer cómo el marco organizativo de La Graciosa encaja en un contexto tan particular como el de las islas Canarias. Ello nos lleva a analizar el sistema de representación y gobierno de este enclave para equiparar, o al menos asimilar, su nuevo estatus con la transferencia de autonomía subjetiva, objetiva e instrumental que debería asistirle. La autonomía local de La Graciosa habría de materializarse con la institucionalización de las correspondientes Administraciones de gobierno local o con la reorganización de sus relaciones con el resto de niveles administrativos que le son propios como el Cabildo de la vecina isla de Lanzarote, a la que pertenece administrativamente, el Gobierno de Canarias y el del Estado.

Palabras clave: autonomía, isla, comunidad autónoma, Canarias, pedanía, gobernanza, participación, organización territorial, Estatuto de Autonomía, Cabildo Insular.

\section{COMMENTS ON THE INSULARITY OF LA GRACIOSA IN THE NEW STATUTE OF AUTONOMY OF THE CANARY ISLANDS}

\section{Abstract}

The new Statute of Autonomy of the Canary Islands has introduced a serie of interesting features acording to administrative law. The feature that this article focuses is the legal consideration of La Graciosa as an "island." This new status must be studied in order to understand how the organisational framework of La Graciosa fits in a territorial context as peculiar as the Canary Islands. This requires a study of the system of representation and government of this island in order to equate its new status with the transfer of the appropriate autonomy which should assist it. This autonomy should be materialised in the institutionalisation of the corresponding local government administrations or the reorganisation of its relations with its other administrative levels as the Council of the neighbouring Island of Lanzarote, the Canary Islands Government, and that of the State.

KEYwORDs: autonomy, island, Canary Islands, district, governance, participation, territorial organisation, Statute of Autonomy, Island Council. 


\section{INTRODUCCIÓN}

La aprobación de la Ley 1/2018, de 5 de noviembre, de reforma del Estatuto de Autonomía de Canarias trajo consigo la satisfacción de algunas demandas que determinados sectores de la vida política y social del archipiélago habían venido formulando desde hace un tiempo. No en vano, el caso canario era uno de los pocos en los que aún no se había practicado la renovación de su primer Estatuto de Autonomía, debido, entre otras cosas, a la dilación que los tiempos parlamentarios y negociaciones políticas habían producido en un marco tan poco propicio como han sido estos últimos ejercicios de legislatura precipitadamente cerrados.

Son bastantes las novedades que introdujo el nuevo Estatuto, y de entre ellas, una de las más interesantes podría situarse en la reforma del régimen electoral y de representatividad parlamentaria con que algunos sectores sociales y políticos reivindicaban la necesidad de abandonar el sistema de triple paridad entre las dos provincias, entre las denominadas islas mayores y entre las hasta entonces cinco islas menos pobladas con las dos más pobladas. En el bronco debate de redacción de la propuesta de Estatuto, desarrollado en el seno del parlamento autonómico, se fraguó el acuerdo de aprobar un sistema mixto que tuviera en cuenta por un lado la representatividad de cada isla en la Cámara regional y por otro lado la reserva de un determinado número de escaños a una lista regional que aproximase la composición de la Cámara al principio de igualdad de valor de los votos emitidos por el conjunto de electores canarios, frente al anterior sistema electoral, que, si bien había sido autorizado por la STC 225/1998, de 25 de noviembre ${ }^{1}$, había dado origen a una importante diferencia de valor entre los votos de los electores de una isla y otra.

No obstante, y por no perdernos en el interesante océano jurídico que ha abierto al análisis este nuevo Estatuto, nos interesa centrarnos en una de las novedades de interés para la rama del Derecho administrativo como es la nueva enumeración de las islas Canarias, en la que pasa a contabilizarse a la (ahora) isla de La Graciosa; y que se concreta en el art. 65.1 del nuevo Estatuto, que establece que «la organización territorial de Canarias se integra por las islas de El Hierro, Fuerteventura, Gran Canaria, La Gomera, Lanzarote, La Palma y Tenerife. La isla de La Graciosa estará agregada administrativamente a Lanzarote, así como los islotes de Alegranza, Montaña Clara, Roque del Este y Roque del Oeste y el de Lobos a Fuerteventura.» El objetivo pues, de este artículo es el de determinar la traducción de esta proclamación en el campo del Derecho administrativo, y contribuir a la apertura de un debate jurídico en el que se resuelva la situación organizativa a la que la isla de La Graciosa se puede asimilar.

${ }^{1}$ STC 225/1998, de 25 de noviembre (BOE núm. 312, de 30 de diciembre de 1998). 


\section{2. ¿QUÉ CONSECUENCIAS JURÍDICAS COMPORTA DICHA PROCLAMACIÓN?}

Sin lugar a dudas, desde un punto de vista administrativo, el signo más reconocible de la isla en el archipiélago canario es el de su gobierno y administración al abrigo de su correspondiente Cabildo Insular, entidades reconocidas y reguladas en los arts. 65 y siguientes del nuevo Estatuto, así como en la legislación específica protagonizada por la Ley 8/2015, de 1 de abril, de Cabildos Insulares. Este tipo de entidades, desde la creación de su versión moderna en el año 1912, y a lo largo de sus diferentes reformas normativas, ha venido experimentando un crecimiento tal que ha desplazado a la figura de las diputaciones provinciales en las islas, vaciando primero y sustituyendo después a estos institutos en el ámbito territorial de cada una de las islas a excepción de La Graciosa, que en todo momento ha formado parte de la organización insular de Lanzarote y municipal de Teguise.

Precisamente, el caso de La Graciosa es el más particular desde el prisma del Derecho administrativo, porque de su realidad demográfica y económica se desprende una dificultad para su organización y administración que requeriría de fórmulas ad hoc para su superación. Nos referimos en este punto al hecho de que la figura del Cabildo como tal está llamada a la organización y coordinación de los municipios de su ámbito territorial, así como a la facilitación de relaciones entre la isla y el Gobierno de Canarias, de modo que sirven a una naturaleza bifronte de organización de la realidad interna de la isla y a su relación con el Ejecutivo regional, como corresponde a un ámbito de insularidad ( $\mathrm{y}$ a veces doble insularidad) que condiciona el desarrollo general de cada isla en Canarias.

En un ejercicio de aplicación de esta figura tradicional para la hipotética constitución de una administración en La Graciosa, contemplamos la concurrencia de diversos problemas en la isla, en la que entre otras circunstancias se da el hecho de que su población se reparte en dos núcleos poblacionales: Caleta de Sebo (730 habitantes) y Pedro Barba (3 habitantes), de acuerdo con los datos ofrecidos por el INE para el año 2018. Este dato poblacional, unido al hecho de que el asentamiento permanente de personas es una realidad históricamente reciente, ha propiciado que estas poblaciones hayan estado circunscritas hasta la actualidad al municipio de Teguise, en la isla vecina de Lanzarote. El hecho de que La Graciosa se haya administrado como enclave integrado en el municipio de Teguise, que en su traducción organizativa se ha venido saldando con la asignación de un concejal específico para la atención y gobierno de La Graciosa, supone el reconocimiento de una realidad geográfica y social específica en este enclave; sin embargo, esta forma de gestión es susceptible de revisión, especialmente si considerásemos que la proclamación de la insularidad de La Graciosa requiere que se la dote de contenido, con lo que tal vez la actual organización de esta isla sea una solución que no pueda tener una trayectoria mucho más duradera en el tiempo.

Fuera como fuese, nos llama poderosamente la atención el hecho de que no se haya podido encontrar hasta la fecha una solución jurídica que equipare a La Graciosa no ya con el resto de islas del archipiélago canario, sino con el resto de muni- 
cipios, cuestión que puede ser ahora más interesante de abordar habida cuenta de la nueva consideración insular de este territorio.

Claro que esta cuestión no es baladí, menos en los tiempos que corren, donde las sucesivas reformas sobre el régimen local han ido limitando la posibilidad de creación de nuevos municipios mediante la obligatoriedad de que los municipios resultantes de una escisión de un territorio para la creación de un municipio independiente está condicionada a que el municipio resultante cuente al menos con 5000 habitantes, a que los municipios transformados sean financieramente sostenibles, a que cuenten con recursos suficientes para el cumplimiento de las competencias municipales y a que ello no suponga disminución en la calidad de los servicios que venían siendo prestados, tal y como establece el art. 13 de la ley 7/1985, de 2 de abril, reguladora de las bases del régimen local, cuya redacción además prefiere sugerir una tendencia hacia la fusión de municipios antes que hacia su segregación.

En todo caso, este punto de debate debe contemplar algunos aspectos muy específicos que influirían en la sostenibilidad financiera del municipio de Teguise y, especialmente, de un hipotético municipio de La Graciosa, como son el hecho de que determinados servicios mínimos, de los contemplados en el art. 26 de la Ley $7 / 1985$, tendrían un ahorro considerable atendida la inexistencia de carreteras asfaltadas en el interior del enclave y que el único medio de acceso a la isla (el marítimo) no sería responsabilidad de Ayuntamiento alguno; y, sin embargo, sí deberían asumir algunas competencias de ejecución costosa a la vista de las características presentes en la realidad de la isla como son las relacionadas con la gestión del medio ambiente o el turismo, que presentan unos valores muy importantes para el ámbito de La Graciosa. Sin embargo, todo este análisis, que debería ser más profundo y riguroso, quedaría en papel mojado atendiendo al hecho (ya anteriormente apuntado) de que el enclave de La Graciosa está habitado por aproximadamente 733 personas, incumpliendo objetivamente uno de los requisitos exigidos por la legislación de régimen local como son el número mínimo de habitantes para su segregación.

Precisamente, y en atención a las reformas en materia de régimen local que pueden traerse a colación para la búsqueda de una alternativa para su organización autónoma, no podemos olvidar que una hipotética consolidación de La Graciosa como pedanía de Teguise no vendría a aportar nada en el plano competencial ni de gestión, dada la negación de personalidad jurídica a estos entes operada por la ley 27/2013, de 27 de diciembre, de racionalización y sostenibilidad de la Administración Local. Además, no está claro que los habitantes de esta isla deseen una forma concreta de autonomía, lo que debería resolverse en un plano más participativo en el seno de la sociedad graciosera.

Con todo ello, el foco de este artículo no pretende bendecir ninguna solución concreta: primero, porque no pretende esta investigación jurídica suplantar el campo de actuación de la decisión política, sino observar la situación de esta isla y su posición en el tablero de la organización jurídico-territorial, y segundo, porque no queda clara cuál es la voluntad del conjunto de vecinos de La Graciosa con respecto a su futuro administrativo, con lo cual no se trata de introducir a la fuerza la puesta en marcha de una administración sobredimensionada dadas las caracterís- 
ticas demográficas de la isla, sino, muy al contrario, de proponer y ejecutar un sistema de organización, administración, representación y participación ad hoc que, precisamente, sea sensible con la realidad de insularidad extrema y sus especiales circunstancias económicas, sociales, medioambientales y políticas de su particular hecho insular.

En este sentido, es evidente pues que la actual coyuntura económica hace desaconsejable, y el ordenamiento vigente hace imposible, la creación de una organización administrativa local propia y autosuficiente que pretenda hacer de este enclave una población con una verdadera cuota de autonomía local que haga efectiva la equiparación administrativa de La Graciosa con las islas a las que ahora iguala en dignidad por esta vía estatutaria. Ahora bien, si este Estatuto de Autonomía, es decir, esta Ley de carácter orgánico aprobada por el Congreso de los Diputados, no permite ningún margen de actuación para llenar de contenido esta denominación, ¿̨hemos de comprender que en realidad esta nueva denominación es un mero simbolismo, vacío de instrumentos que permitan un verdadero ejercicio de la autonomía que la Constitución española reconoce a las islas en los archipiélagos balear y canario ex art. 141.4 CE? Veámoslo por partes, pues son muchas las cuestiones que se suscitan desde un punto de vista del Derecho administrativo en torno a este nuevo estatus.

Primero, desde el punto de vista simbólico, que a priori es el más palpable, podemos apreciar que se ha procedido a la reforma de distintos símbolos, como el himno de la comunidad autónoma, que, estando regulado en la Ley 20/2003, de 28 de abril, del Himno de Canarias, ve modificar su letra para la sustitución de los versos repartido en siete peñas alusivo a las islas que conforman el archipiélago por el de repartido en ocho peñas, según recoge el acuerdo el consejo de Gobierno de Canarias, de 21 de enero de 2019, que insta a la Consejería de Presidencia, Justicia e Igualdad a la tramitación, con carácter de urgencia, de una iniciativa legislativa dirigida a ejecutar dicha modificación. A esta modificación se le debería unir más pronto que tarde la modificación de la bandera oficial, y la del escudo, para dibujar en ellas la nueva isla que ahora reconoce el EAC y que debería estar representada en estos emblemas como todas las demás ínsulas del archipiélago.

No cabe duda de que esta renovación de símbolos es la traducción a la realidad del reconocimiento de La Graciosa como octava isla canaria, que empieza a ver sus frutos en el tablero institucional. Sin embargo, reconocemos que estas apreciaciones simbólicas merecen un análisis muy exhaustivo, que desbordan el Derecho administrativo, y que pasan a ser objeto de análisis de otras disciplinas como la ciencia política o la sociología, en lo que se refiriere al marcado simbolismo de esta nueva consideración territorial. Nos referimos en realidad a una de las connotaciones más destacables de la denominación de La Graciosa como octava isla. Y es que, por abordar el ejemplo, las relaciones comerciales, afectivas y sociales que han unido tradicionalmente a Canarias con Venezuela ya habían forjado la consideración del país caribeño como la octava isla canaria en una denominación reconocida a nivel social, político, cultural e institucional. Por ello, comprobamos que la tradicional consideración de las islas Canarias como una suma de siete territorios (al que se le ha unido por afecto Venezuela) requiere de una revisión que permita responder a 
la integración y dignificación de La Graciosa como isla, compatible con las implicaciones culturales que esta operación aritmética ha comportado históricamente.

Por otro lado, y regresando a aspectos más puramente territoriales, no se nos puede escapar el hecho de que la nueva enumeración funciona, intencionada o accidentalmente, como una manera de equiparar el número de islas en ambas provincias canarias, de manera que tanto Las Palmas como Santa Cruz de Tenerife extenderían su territorio sobre un número de ínsulas idéntico. De este modo, se mantendría vigente la idea de paridad e igualdad entre islas y provincias tan recurrente en determinados resurgimientos del pleito insular, y que con la proclamación del primer Estatuto en los años 80 se hiciera palpable precisamente con el reparto de la representatividad parlamentaria bajo el principio de triple paridad. Aunque ello, nuevamente, encontraría una interpretación más acertada en otros campos del conocimiento como el de la ciencia política, que debería responder de la traducción de este fenómeno de equiparación provincial en su campo habida cuenta del peculiar mapa canario, en el que en realidad han sido más frecuentes las ambiciones insularistas que las de carácter provincialista.

En otro orden de cosas, y para terminar de valorar la cuestión de saber si el nuevo Estatuto de Autonomía se limita a reconocer la existencia de una isla vacía de competencias contradiciendo el derecho constitucionalmente proclamado en el art. 141 de nuestra Carta Magna, podemos establecer una serie de afirmaciones. A nuestro juicio, el Derecho no puede permanecer mudo ante esta inactividad del ejercicio de la autonomía que La Graciosa parece asumir con su dignificación de isla, incluso si el art. 65.1 EAC se cura en salud al declarar que la entidad resultante de esta declaración «estará agregada administrativamente a Lanzarote». Primero, porque, de ser así, el propio Estatuto estaría reconociendo ya no el absurdo de proclamar una entidad vacía de contenido, sino haciendo una declaración expresa de inconstitucionalidad al proclamar el nacimiento jurídico de una isla que no es tal en Derecho. Segundo, porque el propio legislador autonómico estaría perdiendo la oportunidad histórica de responder a la necesidad de organización de las poblaciones existentes en La Graciosa desde un punto de vista jurídico acorde con los actuales tiempos de gobernanza y participación.

De este modo, es evidente que las regulaciones actuales en materia de régimen local imposibilitan la ejecución de una fórmula tradicional tendente a igualar la isla de La Graciosa al resto de islas con la constitución de su signo más reconocible, el Cabildo Insular, pero obliga en su contenido a encontrar y poner en marcha aquellos instrumentos que de acuerdo con los principios de eficiencia y eficacia den sentido a esta declaración de igualdad institucional con que el estatuyente ha querido colocar a La Graciosa con respecto a sus iguales, el resto de islas. El Derecho administrativo conoce estos instrumentos, y los conoce de la mano del desarrollo de las políticas públicas actuales que buscan la participación de los ciudadanos, con lo que la equiparación insular podría perfectamente estructurarse alrededor de un sistema de representación y participación más ventajoso para la isla de La Graciosa en el Parlamento regional (con la asignación de un escaño específico para la isla) y el establecimiento de alguna relación de comunicación más estrecha con el Gobierno canario que la haga más autónoma del Ayuntamiento de Teguise y de la 
isla de Lanzarote, de la que en realidad continuaría formando parte administrativa y políticamente. Esta relación con el Gobierno de Canarias podría plantearse de múltiples formas, siendo tal vez la menos gravosa la de establecimiento de un delegado que permitiera un canal de comunicación y participación directa entre los habitantes de La Graciosa y el Ejecutivo regional, de modo que se conseguiría dotar a la isla de una de las bondades de contar con Cabildo propio (como es el refuerzo de la relación institucional isla-comunidad autónoma) sin los perjuicios económicos y materiales de constituirlo. Estas fórmulas podrían desarrollarse al abrigo de una eventual reforma de la Ley de cabildos, de manera que pudiera flexibilizarse para la isla de La Graciosa la asignación de un ente equiparable al Cabildo al que se le eximiese de requisitos fundamentales de su constitución como son la existencia de municipios a los que coordinar, de manera que en realidad se le estaría otorgando a dicha isla un tipo de entidad cuya naturaleza se encontraría a medio camino entre el Ayuntamiento y el Cabildo, y tal consideración necesitaría de un estudio en profundidad de la normativa estatal y autonómica en materia de régimen local y más específicamente de la creación de una entidad ad hoc para la respuesta a esta variación organizativa en la planta territorial del archipiélago canario.

No obstante lo anterior, la lista de posibilidades para el encaje de un nuevo modelo de organización de La Graciosa es más extensa, sirviendo a meros efectos enunciativos la propuesta de estos instrumentos, que no han de entenderse como una lista numerus clausus, sino muy al contrario como una manera de contribuir al debate jurídico en que se base la estructura del modelo organizativo de La Graciosa. De este modo, el legislador autonómico estaría desarrollando un verdadero espacio de actividad política y organizativa a la nueva isla que reconoce el estatuyente, completando el contenido de su declaración con una verdadera respuesta jurídica que no se quede en una mera solución de símbolos, y que no sólo observe el ordenamiento concernido, sino que lo desarrolle y termine de darle coherencia con la aplicación de medidas de administración eficientes y modernas.

Asentado todo lo anterior, podemos afirmar que la proclamación de La Graciosa como isla, al abrigo del nuevo EAC, comporta una significación legal que no puede limitarse a una mera actualización de los símbolos institucionales de la comunidad autónoma canaria. Muy al contrario, tal y como proclama nuestra Constitución y desarrolla la legislación en materia de régimen local, la isla ha de configurarse administrativamente de una manera determinada. Con ello, y contextualizado el caso particular de La Graciosa, está claro que tanto la voluntad del estatuyente como las posibilidades legales operadas por las reformas de racionalización y sostenibilidad en el ámbito del sector público implican la necesidad de buscar una solución ad hoc para la dignificación de La Graciosa y para dar contenido a su proclamación como isla. Esta solución no puede ser una de las tradicionalmente escogidas, la constitución de Cabildo propio, al ser inviable económica y legalmente; incluso la creación de un ente a medida puede ser una idea complicada de materializar desde un punto de vista legal y una respuesta insuficiente para abordar la organización administrativa insular de La Graciosa. La solución, por tanto, debe encontrarse en la aplicación de técnicas de gobernanza modernas, y principalmente en las políticas de participación que permitan, primero, saber cuáles son las aspiraciones de autogo- 
bierno de los habitantes de La Graciosa, y segundo, ofrecer un encaje jurídicamente viable a esas aspiraciones con la puesta en marcha de medidas eficientes que doten de autonomía local a esta isla. Estas medidas que hemos propuesto, como ya hemos dicho, pueden ser muy variopintas, completadas, debatidas, pero deben valer para dar una respuesta jurídica a la proclamación que el nuevo Estatuto de Autonomía realiza sobre la isla de La Graciosa.

\section{CONCLUSIÓN}

A modo de conclusión, podemos decir que la proclamación de La Graciosa como isla, operada en el nuevo EAC, se fundamenta en la atención a una demanda tendente a la dignificación de las habitantes de Caleta de Sebo y Pedro Barba, lo que desde un punto de vista jurídico encontraría un excelente objeto de investigación constitucional a propósito de los derechos fundamentales reivindicables en esta demanda, así como en otros campos de conocimiento, a los que probablemente les interesen las consecuencias que comporta en su ámbito esta reconsideración territorial.

Ahora bien, desde el prisma administrativo son otros los debates de interés, enfocados en la traducción de esta nueva consideración insular a las posibilidades organizativas de La Graciosa, y cuyas actuales limitaciones legales obligarían a desarrollar soluciones específicas para esta realidad. Hemos propuesto, a modo meramente enunciativo, soluciones muy distintas: la primera, que reconocemos irrealizable, de crear un Cabildo en dicha isla; la segunda, más viable, crear un ente ad hoc que permita una gestión más autónoma de la isla, y que podría encontrarse a medio camino entre un Ayuntamiento y un Cabildo; y la tercera, la más factible, que implicaría la ejecución de un catálogo de políticas de representación y participación más ventajosas para La Graciosa.

De esta manera, existen herramientas que posibilitarían un encaje novedoso para La Graciosa de acuerdo con los principios de eficiencia que informan al sector público español, que merecen ser estudiadas, debatidas y completadas. Estas se podrían concretar, en el plano de la representación, en la asignación de un escaño en el Parlamento regional a favor de La Graciosa, la dotación de un delegado del Gobierno autonómico en la isla y la integración de un delegado de La Graciosa en el Cabildo Insular de Lanzarote; y en el plano de la participación, en un desarrollo un poco más sensible de las últimas técnicas de gobernanza para fortalecer la voz de los habitantes de la isla, incluso si se mantuviese su actual organización como entidad integrada en el municipio lanzaroteño de Teguise. 


\section{BIBLIOGRAFÍA}

\section{DOCTRINA}

Benítez de Lugo, J.M., El municipio y sus elementos esenciales, Madrid, 1986.

Betancort Reyes, F.J. (coord.), El Estatuto de Autonomía de Canarias, Ley Orgánica 1/2018, de 5 de noviembre, Editorial Iustel, Madrid, 2019.

Caamaño Dominguez, F., La autonomía de los entes locales en positivo, Fundación Democracia y Gobierno Local, Barcelona, 2003.

CRIADO, J., Nuevas tendencias en la gestión pública. Innovación abierta, gobernanza inteligente y tecnologias sociales en unas Administraciones Públicas colaborativas, INAP, Madrid, 2016.

García Morillo, J., La configuración constitucional de la autonomía local, Editorial Marcial Pons ediciones jurídicas y sociales, Madrid, 1998.

Palomar Olmeda (dir.), La Administración en tiempo de Crisis, Aranzadi, Pamplona, 2012.

Parejo Alfonso, L. y Vida Fernández, J. (coords.), Los retos del Estado y la Administración del siglo XXI. Tomo II. Tirant Lo Blanch, Valencia, 2017.

Ramió, C., La administración Pública del Futuro (Horizonte 2050). Instituciones, politica, mercado y sociedad de la innovación, Editorial Tecnos, Madrid, 2017.

Rodríguez-Arana Muñoz, J. y Sarmiento Acosta, M.J. (dirs.), Comentarios a la Ley 27/2013, de 27 de diciembre de racionalización y sostenibilidad de la Administración Local, Editorial Marcial Pons, Granada, 2014.

SÁnchez Saez, A., Autonomía Local y Descentralización, Tirant Lo Blanch, Valencia, 2008.

Sarmiento Acosta, M., Las Competencias de los Cabildos Insulares, Cabildo Insular de Gran Canaria, Las Palmas de Gran Canaria, 1992.

Sarmiento Acosta, M., «Posición institucional, competencias y financiación de los Cabildos Insulares en el estado autonómico». En XX Coloquio de Historia Canario-Americana, Cabildo Insular de Gran Canaria, Las Palmas de Gran Canaria, 2012.

Villar Rojas y Suay Rincón (dirs.), Derecho Local de Canarias, Editorial Iustel, Madrid, 2013.

\section{JURISPRUDENCIA}

STC 225/1998, de 25 de noviembre (BOE núm. 312, de 30 de diciembre de 1998).

\section{Noticia}

«El Senado reconoce a La Graciosa como la octava isla canaria habitada», La Vanguardia, 26 de junio de 2018. https://www.lavanguardia.com/politica/20180626/45418824885/el-senado-reconoce-a-la-graciosa-como-la-octava-isla-canaria-habitada.html. Consultado el 30 de septiembre de 2019.

\section{Estadística}

INE (Instituto Nacional de Estadística). Consultado el 30 de septiembre de 2019. Disponible en http:// www.ine.es/nomen2/index.do. 



\section{REVISORES}

María Dolores Adam Muñoz (Universidad de Córdoba)

Miguel Ángel Boldova Pasamar (Universidad de Zaragoza)

Antonio Cayón Galiardo (Universidad Complutense de Madrid)

María del Pilar Diago Diago (Universidad de Zaragoza)

María José Fernández Pavés (Universidad de Granada)

Gabriel García Cantero (Universidad de Zaragoza)

Pedro González de la Fe (Universidad de Las Palmas de Gran Canaria)

Andrés González Sanfiel (Universidad de La Laguna)

Ulises Hernández Plasencia (Universidad de La Laguna)

Mar Jimeno Bulnes (Universidad de Burgos)

Arantza Libano Beristain (Universidad Autónoma de Barcelona)

José Luis Linares Pineda (Universidad de Girona)

Ángel Lobo Rodrigo (Universidad de La Laguna)

Cesare MaIoli (Universitá di Bologna)

José María Miquel González (Universidad Autónoma de Madrid)

Cristóbal Molina Navarrete (Universidad de Jaén)

María del Carmen Núñez Lozano (Universidad de Huelva)

Javier Plaza Penadés (Universidad de Valencia)

Encarnación Ricart Martí (Universidad Rovira y Virgili de Tarragona)

Gloria Pilar Rojas Rivero (Universidad de La Laguna)

Dulce María Santana Vega (Universidad de Las Palmas de Gran Canaria)

Eloy Ruiloba García (Universidad de Málaga)

Gumersindo Ruiz Bravo de Mansilla (Universidad de Málaga)

Ambrosio Sampere Flores (Universidad de Murcia)

María Elena SÁnchez JordÁn (Universidad de La Laguna)

José Luis Sánchez-Parodi Pascua (Universidad de La Laguna)

Dulce María Santana Vega (Universidad de Las Palmas de Gran Canaria)

José María Souvirón Morenilla (Universidad de Málaga)

José Suay Rincón (Universidad de Las Palmas de Gran Canaria)

José Manuel Ventura Ventura (Universidad de La Rioja)

Francisco Villar Rojas (Universidad de La Laguna)

María Zambonino Pulito (Universidad de Cádiz) 

INFORME DEL PROCESO EDITORIAL DE ANALES DE LA FACULTAD DE DERECHO DE LA UNIVERSIDAD DE LA LAGUNA 36, 2019

El equipo de dirección se reunió a finales del mes junio de 2020 para tomar decisiones sobre el proceso editorial del número 36 de AFDULL. El tiempo medio transcurrido entre recepción, evaluación, aceptación, edición y publicación final de los trabajos fue de cuatro meses.

Estadística:

Núm. de trabajos recibidos: 6 .

Núm. de trabajos aceptados para publicación: 3 (50\%).

Media de revisores por trabajo: 2 .

Media de tiempo entre envío y aceptación: 4 meses.

Media de tiempo entre aceptación y publicación: 6 meses.

Los revisores varían en cada número, en atención al tema de los trabajos presentados. 

(Adoptadas por el Consejo de Redacción en su sesión de 9 de abril de 2018; pendientes de ratificación por la Junta de la Facultad de Derecho)

Primera. La revista se publica en formato digital, en un número anual, con dos fascículos semestrales a través de la plataforma de gestión de revistas on line de la Universidad de La Laguna: http://revistas.webs.ull.es/index.php/derecho. Los trabajos que se presenten al proceso de selección para su publicación deberán cumplir las siguientes normas:

a) Plazo y forma de presentación. La revista tiene permanentemente abierta su convocatoria de propuestas de publicación. Las propuestas podrán ser sometidas a consideración por sus autores a través de la plataforma de gestión de revistas on line de la Universidad de La Laguna: http://revistas.webs.ull.es/index.php/derecho.

b) Autores. Solo podrán presentar trabajos en la revista aquellas personas que reúnan la cualidad de titulados en alguna de las enseñanzas universitarias oficiales de Grado, Máster y Doctorado, o categorías equivalentes. Los autores deberán identificar su categoría académica y/o profesional, así como cuál es la institución a la que pertenecen.

c) Temática. Los trabajos deben ser investigaciones de contenido jurídico.

Excepcionalmente y de manera subsidiaria podrán incluirse trabajos de materias afines si los miembros del Consejo de Redacción asistentes unánimemente así lo consideran.

d) Estructura y formato de los trabajos.

I. Para la sección Artículos: los trabajos no deben exceder de los 60000 caracteres con espacios (unas 20 páginas) y tendrán un título (en español e inglés), como mínimo tres palabras clave (en español e inglés) y un resumen (en español e inglés). No deberá incluirse ni sumario ni bibliografía final. Las propuestas de publicación se presentarán en archivo en formato editable: Word o rtf.

II. Para la sección Comentarios, de legislación y jurisprudencia: los trabajos no deben exceder de los 30000 caracteres con espacios (unas 10 páginas) y tendrán un título (en español e inglés), como mínimo tres palabras clave (en español e inglés) y un resumen (en español e inglés). No deberá incluirse ni sumario ni bibliografía final. Las propuestas de publicación se presentarán en archivo en formato editable: Word o rtf.

III. El formato del texto principal será Times New Roman, a espacio y medio, tamańo de letra 12; y para las notas a pie de página es Times New Roman, a un espacio y con tamaño de letra 10. Las normas para las citas son las siguientes: A) Artículos de revistas. Ejemplo: SAavedra Ruiz, J., «La iniciativa del tribunal en el acto del juicio oral", Cuadernos de Derecho Judicial, n. ${ }^{\circ} 10,1994$, p. 13 y ss. B) Libros/monografías. Ejemplo: Ortells Ramos, M., El proceso penal abreviado, Comares, Granada, 1997.

e) Idioma. Los trabajos deberán estar escritos en lengua espańola, o en alguna lengua extranjera de relevancia en el ámbito jurídico siempre que la revista cuente con revisores que conozcan la lengua extranjera y sean expertos en el área de conocimiento de la propuesta presentada. En todo caso, el título, las palabras clave y el abstract deberán presentarse en español e inglés. 
f) Originalidad de los trabajos. Todos deben ser inéditos y no deben estar pendientes de publicación en otra revista o libro.

Segunda. La presentación de un trabajo en la revista Anales de la Facultad de Derecho de la Universidad de La Laguna conlleva el conocimiento y la aceptación de las siguientes normas por parte de los autores:

1. Es condición para la publicación que el autor o autores ceda(n) a la revista, en exclusiva, los derechos de reproducción, así como que consientan su inclusión en bases de datos, catálogos, bibliotecas, índices o servidores que permitan la mayor difusión de las investigaciones. Si se producen peticiones de terceros para reproducir o traducir artículos o partes de los mismos, la decisión corresponderá al Consejo de Redacción.

2. De las opiniones sustentadas en los trabajos firmados responden exclusivamente sus autores. La publicación de los diferentes artículos no implica adhesión ni conformidad de la revista con las opiniones mantenidas por los autores.

Tercera. Se asignará uno o dos evaluadores, preferiblemente externos, por cada uno de los originales presentados, según la materia sobre la que versen los mismos, para que informen en el plazo que se establezca sobre la conveniencia de su publicación. La evaluación será anónima en todo momento, de manera que los autores no conocerán quién evaluó su trabajo ni el evaluador conocerá quién es el autor.

Cunta. Pese a ser la evaluación anónima, en el caso de concurrir causa de abstención en alguno de los miembros propuestos o cuando este lo proponga de manera motivada, se podrá designar a otro/s evaluador/es experto/s en la materia que se evalúa.

Quinta. Cada evaluador rendirá su informe teniendo en cuenta los siguientes criterios: la calidad y rigor de los argumentos presentados; la oportunidad y relevancia del artículo; la creatividad, metodología, propuestas y aportaciones; así como la adecuación a las normas de publicación. Los informes tendrán carácter confidencial y reservado.

Sexta. Una vez transcurrido el plazo para presentar los informes de evaluación, se reunirá el Consejo de Redacción, al que se dará cuenta del punto en el que se encuentra el proceso, llevándose a cabo la valoración del resultado de las evaluaciones. Cuando exista contradicción entre los informes emitidos, el Consejo de Redacción designará a un tercer experto en la materia, para que proceda a una nueva evaluación.

SÉptima. Se trasladará al autor el resultado de la evaluación y, en su caso, las modificaciones sugeridas por los expertos, con la advertencia de que el Consejo de Redacción se reserva el derecho a no publicar el original presentado cuando no se observaren las modificaciones propuestas por los expertos.

Octava. Cuando algún miembro del Consejo de Redacción fuere autor del original presentado deberá ausentarse de las votaciones. 


\section{Servicio de Publicaciones \\ Universidad de La Laguna}

